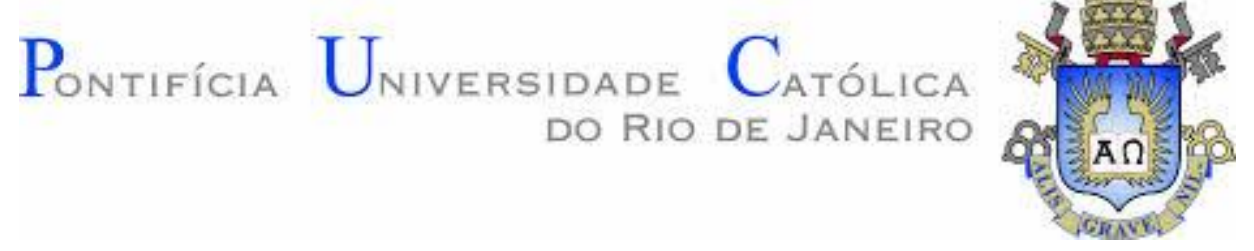

Janaina de Oliveira Santos

\begin{abstract}
A poesia como linguagem da realidade: as referências poéticas de Pier Paolo Pasolini a uma ideia de poesia dialetal italiana
\end{abstract}

Dissertação de Mestrado

Dissertação apresentada ao Programa de Pós-Graduação em História Social da Cultura da PUC-Rio como requisito parcial para obtenção do título de Mestre em História.

Orientador: Prof. Henrique Estrada Rodrigues 


\title{
Pontifícia Universidade Católica

Janaina de Oliveira Santos

\section{A poesia como linguagem da realidade: as referências poéticas de Pier Paolo Pasolini a uma ideia de poesia dialetal italiana}

Dissertação apresentada como requisito parcial para obtenção do grau de Mestre pelo Programa de PósGraduação em História Social da Cultura do Departamento de História do Centro de Ciências Sociais da PUC-Rio. Aprovada pela Comissão Examinadora abaixo assinada.

\author{
Prof. Henrique Estrada Rodrigues \\ Orientador \\ Departamento de História - PUC-Rio
}

Prof. Felipe Charbel Teixeira Instituto de História - UFRJ

Prof. Daniel Pinha Silva

Departamento de História - PUC-Rio

Profa Mônica Herz

Vice-Decana de Pós-Graduação do Centro de Ciências Sociais

PUC-Rio

Rio de Janeiro, 05 de outubro de 2015 
Todos os direitos reservados. É proibida a reprodução total ou parcial do trabalho sem autorização da universidade, da autora e do orientador.

Janaina de Oliveira Santos

Graduou-se em História na UFRJ (Universidade Federal do Rio de Janeiro) em 2011. Participou de diversos congressos na área de História e Historiografia.

Ficha Catalográfica

Santos, Janaina de Oliveira

A poesia como linguagem da realidade: as referências poéticas de Pier Paolo Pasolini a uma ideia de poesia dialetal italiana / Janaina de Oliveira Santos ; orientador: Henrique Estrada Rodrigues. - 2015.

136 f. ; 29,7 cm

Dissertação (mestrado) - Pontifícia Universidade Católica do Rio de Janeiro, Departamento de História, 2015

Inclui bibliografia

1. História - Teses. 2. História social da cultura. 3. Pasolini, Pier Paolo. 4. Dante. 5. Pascoli, Giovanni. 6. Croce, Benedetto. 7. Contini, Gianfranco. 8. Poesia italiana. 9. Ensaios pasolinianos. I. Rodrigues, Henrique Estrada. II. Pontifícia Universidade Católica do Rio de Janeiro. Departamento de História. III. Título. 


\section{Agradecimentos}

Agradeço, em primeiro lugar, aos meus pais, Selma e Ademir, por me aturarem nos momentos de surto, em meio à escrita numa casa que nunca foi silenciosa;

Em segundo lugar, e como agradecimento mais importante, ao meu orientador Henrique Estrada Rodrigues, por ter aceitado embarcar no mundo quase desconhecido de Pasolini junto comigo, em uma aventura inédita para ambos;

Ao meu amigo Bruno Boto, por ter me apresentado o Pasolini ensaísta;

Ao meu antigo professor e amigo Carlos Ziller, por sua opinião forte e sua sinceridade;

A Felipe Charbel, pela sua atenção aos meus questionamentos acadêmicos;

Às minhas amigas-irmãs, Gabriela Mitidieri e Sheila Leal, por irem comigo do choro ao riso, e que, apesar dos percalços, estão comigo há dez anos, sendo minhas leitoras assíduas;

Ao Igor, que, apesar da recente amizade, tornou-se um fiel companheiro, apesar de suas tentativas de me levar ao alcoolismo;

À Priscila Alba, que caminha comigo em uma mesma jornada desde a graduação, enfrentando os mesmos desvios e as mesmas vitórias;

As duas amigas que a PUC me deu, Clarissa Mattos, por partilhar comigo as neuras e manias, e Maria Noujaim, por ser a calmaria que me concede o equilíbrio;

Aos meus tantos outros amigos, que há três anos entendem as minhas ausências, devido à minha dedicação aos estudos, Fernanda, Marcella, Manuela, Raphael e Thaís;

Ao Sílvio por sua amizade incondicional e paciência;

Ao Marco, por tentar me mostrar o quanto há de amor, generosidade e beleza na vida; 


\section{Resumo}

Santos, Janaina de Oliveira; Rodrigues, Henrique Estrada. A poesia como linguagem da realidade: as referências poéticas de Pier Paolo Pasolini a uma ideia de poesia dialetal italiana. Rio de Janeiro, 2015. 136 p. Dissertação de Mestrado - Departamento de História, Pontifícia Universidade Católica do Rio de Janeiro.

Em 1960, Pier Paolo Pasolini publicou pela editora Einaudi seu livro de ensaios poéticos, intitulado Passione e Ideologia. Essa obra reflete a relação afetiva e intelectual do autor com a poesia dialetal italiana. Partindo do recolhimento dos cantos dialetais feitos por folcloristas do Oitocento, tais como Pitrè, Tommaseo e Nigra, Pasolini elucubrou a poesia dialetal como a poesia popular italiana por excelência. Nesse sentido, pretende-se demonstrar como Pasolini, mediado pela leitura dos trabalhos dos críticos Benedetto Croce e Gianfranco Contini, promoveu um mapeamento das principais referências que justificariam as possíveis afinidades da poesia em dialeto com a poesia dita popular. Autores como Dante, Vico, Rousseau, Herder e Giovanni Pascoli foram mobilizados por ele dentre aqueles que pensavam a poesia como sendo a primeira linguagem entre os homens, sendo ela proveniente do vulgo e, sobretudo, como fruto de uma atividade sentida e imaginada.

\section{Palavras-Chave}

Pier Paolo Pasolini; Dante; Giovanni Pascoli; Benedetto Croce; Gianfranco Contini; Poesia italiana; ensaios pasolinianos. 


\section{Abstract}

Santos, Janaina de Oliveira; Rodrigues, Henrique Estrada (Advisor). Poetry as a language of reality: the poetic references of Pier Paolo Pasolini an idea of italian dialectal poetry. Rio de Janeiro, 2015. 136p. MSc. Dissertation - Departamento de História, Pontifícia Universidade Católica do Rio de Janeiro.

In 1960, Pier Paolo Pasolini published by Einaudi publishing his book of poetic essays entitled Passione e Ideologia. That work reflects the emotional and intellectual relationship of the author with the Italian dialectal poetry. Starting from the gathering of dialectal songs done by folklorists of the Italian Oitocento such as Pitrè, Tommaseo and Nigra, Pasolini thought over the dialectal poetry as a popular Italian poetry par excellence. In this sense, we intend to demonstrate how Pasolini, refereed by reading the works of the critics Benedetto Croce and Gianfranco Contini, promoted a mapping of the main references that justify the possible affinities of poetry in dialect with a alleged folk poetry. Authors such as Dante, Vico, Rousseau, Herder and Giovanni Pascoli were mobilized by him among those who thought poetry as the first language of men, coming from the vulgar, and above all, as the result of a felt and imagined activity.

\section{Keywords}

Pier Paolo Pasolini; Dante; Giovanni Pascoli; Benedetto Croce; Gianfranco Contini; italian poetry; Pasolini`s essays 


\section{Sumário}

1.Introdução 8

2. As referências teóricas de Pier Paolo Pasolini: de Vico a Croce

2.1. A poesia primitiva em Vico: antecedentes de uma ideia de poesia popular

2.2. Rousseau: as línguas e a necessidade de socialização entre os homens

2.3. Herder e a origem das línguas: as influências do movimento romântico

2.4. A noção de poesia entre alguns românticos alemães

2.5. A (des) construção de uma ideia de poesia popular: Vico e o romantismo por Benedetto Croce

2.6. Pasolini leitor de Croce: uma crítica à Poesia popolare e poesia d'arte

3. As referências poéticas de Pier Paolo Pasolini: de Dante a Gianfranco Contini

3.1 Dante Alighieri e Francesco Petrarca: uma ideia de linguagem em oposição

3.1.1 Dante Alighieri: entre o pluri e o monolinguismo

3.2. A crítica de Croce a Dante Alighieri e a Giovanni Pascoli

3.3. Gianfranco Contini: de Dante a Pascoli

3.4. Entre o mono e o plurilinguismo: a análise de Pasolini acerca da tradição poética italiana

4.Pasolini ensaísta

4.1. A obra ensaística pasoliniana 107

4.2. A querela entre Pasolini e Italo Calvino 109

4.2.1. As fábulas italianas 112

4.2.2. A língua dialetal e a língua média 117

5. Considerações Finais 131

6. Referências Bibliográficas 134 


\section{Introdução "O gosto da vida e do realismo": a relação de Pasolini com a poesia em dialeto}

(...) a intimidade com este dialeto deu-me o gosto da vida e do realismo. Através do friulano, aprendia que as pessoas simples, através de sua linguagem, acabam por existir objetivamente, como todo mistério de seu caráter de camponês (...) O tempo ia ensinar-me pouco a pouco a usar o dialeto como um instrumento de pesquisa objetiva, realista ${ }^{1}$.

Em agosto de 1975, alguns meses antes de seu assassinato, Pier Paolo Pasolini concedeu sua última entrevista ao escritor Jean Duflot, na qual rememora o caminho percorrido ao longo de sua trajetória intelectual. Na ocasião, o escritor aponta suas principais influências, a importância da família nas suas escolhas profissionais e, mais do que tudo, como chegou a se tornar um intelectual dedicado a tantas atividades. Poeta, romancista, ensaísta, roteirista, cineasta - são muitas as definições em que poderia Pasolini ser encaixado. Contudo, acima de todas essas, está a de um intelectual que pensava a questão da cultura dialetal na Itália, vendo como elemento crucial dessa cultura a questão da linguagem. Desde a composição de seus primeiros poemas, passando à elaboração de seus primeiros ensaios, até a produção de seus primeiros filmes, é possível notar sua preocupação em discutir a linguagem em suas mais variadas formas.

Quanto à questão de suas relações com a cultura dialetal, nota-se uma constante menção ao dialeto friulano (uma das três línguas que eram faladas em Friul), em função da relevância deste na formação intelectual e pessoal de Pasolini. Era desta região que vinha a família materna de Pasolini, tendo aí passado frequentemente férias enquanto jovem, e, assim, entrado em contato com essa língua. A motivação do artista para uma imersão no mundo dialetal, tal como ele mesmo afirmou, foi a sensação de que a experiência diante daquela realidade campesina provocou nele "o gosto de vida e de realismo". A Pasolini, o cotidiano dos homens do campo, que viviam em contato direto com a natureza, valorizavam

\footnotetext{
${ }^{1}$ PASOLINI, P. P., As últimas palavras do herege: entrevistas com Jean Duflot, p. 24
} 
o modo de vida campesino perante à realidade urbana, burguesa, na qual crescia Pasolini e seu irmão, Guido. Motivado pela diversidade, pelo contato direto com um cotidiano que parecia ter parado no tempo, ele deu início à sua “investigação arcaica" ${ }^{2}$, estudando o idioma friulano.

O uso que Pasolini fazia deste dialeto, "como instrumento de pesquisa objetiva, realista", encontrava obstáculos diante de uma língua que se transformava constantemente, já que não havia sido pré-determinada pela gramática. O friulano fazia parte, sobretudo, de uma tradição oral, e era desta forma transmitido entre as pessoas que viviam dentro daquela realidade campesina através da fala. A isto Pasolini define como "existência objetiva". Assim, a investigação arcaica que o artista se propôs a realizar para compreender aquele dialeto ocorreu mediante duas maneiras: a escrita de poemas e uma pesquisa entre as pessoas que viviam no Friuli. O jovem pôde então compreender o que definiu como uma existência objetiva entre os camponeses. Esse contato foi fundamental para que ele pudesse afirmar que a relação com o mundo dialetal deu a ele "o gosto de vida e de realismo".

Assim, aliando um método de estudo prático e teórico, Pasolini foi capaz de se inserir dentro daquela realidade a ponto de produzir seus primeiros poemas em friulano. Tinha início a partir dessa prática a construção do que se pode definir como o realismo em Pasolini: uma interpretação do mundo a partir de uma "experiência sensível da vida terrena", ou melhor, da experiência sensível da vida camponesa no Friuli, elaborada por intermédio de um estudo sobre a língua friulana. Havia no jovem Pasolini um desejo de compreender como aquele dialeto era utilizado por aquelas pessoas no dia a dia, de como aquelas palavras eram pronunciadas em momentos tristes ou felizes.

A primeira forma de Pasolini esboçar aquilo que aprendeu a partir do contato com o mundo dialetal foi escrevendo seus primeiros poemas, aos sete anos. A composição de poemas foi a primeira atividade intelectual em que ele pôde exercsua escrita, inspirado pelo friulano. O resultado de sua escrita poética foi a publicação de seu primeiro livro de poesias dialetais, Poesia a Casarsa (1942), contendo textos que ele escreveu em friulano.

\footnotetext{
${ }^{2}$ Ibid., p. 24
} 
No ano de 1944, quando Pasolini vivia em Casarsa com sua mãe, a cidade sofreu os primeiros bombardeios da Segunda Guerra Mundial, forçando-o a deixar a cidade e refugiar-se em Versuta, local onde passou a lecionar literatura. A estadia em Versuta foi fértil à sua produção intelectual, pois, além das aulas, ele fundou ali, em 1945, a Academia de Lengua Friulana, cujos axiomas estéticos eram o "friulano absoluto, tradição romana, influência das literaturas contemporâneas, liberdade e imaginação"3. A fundação da Academia motivou ainda a criação de uma revista literária denominada Il stroligut. Os anos 40 foram importantes ao desenvolvimento dos estudos de Pasolini sobre a cultura dialetal, sobretudo a língua. O contato mais íntimo com este dialeto foi importante para que ele, ao longo de seus estudos, pensasse na língua dialetal como instrumento de crítica. A composição de seus poemas tornou-se, assim, um meio para criticar um determinado tipo de linguagem usada na composição de textos poéticos:

\begin{abstract}
Escrevi os primeiros poemas friulanos em plena voga do hermetismo, cujo mestre era Ungaretti. À margem de um certo simbolismo provinciano, Montale teimava em seguir poetas como Eliot e Pound enfim, todos os poetas herméticos viviam da ideia de que a linguagem da poesia era uma linguagem absoluta. E daí a se fecharem numa linguagem reservada à poesia, sem nenhuma mistura com a linguagem da prosa, há apenas um passo ${ }^{4}$.
\end{abstract}

Continua Pasolini: “Tomei (...) o partido de ser incompreendido e escolhi para tanto o dialeto friulano. Era para mim o cúmulo do hermetismo, da obscuridade, da recusa de comunicação" ". Porém, o dialeto não era uma língua alheia à vida, não se fechava num unierso linguístico autorreferente. Pasolini, ao

\footnotetext{
${ }^{3}$ Ibid., p. 24.

${ }^{4}$ Ibid. p. 24. O significado da palavra Hermético, em se tratando de poesia e literatura, recebeu um significado negativo. De acordo com a definição que consta nos dicionários, por exemplo, no Grande Dicionário Etimológico-prosódico da Língua Portuguesa: “ Adj. Oculto, fechado impenetrável. O significado atual de completamente fechado provém dos vasos, dos frascos(...) com a dissolução do próprio vidro sob a ação do fogo, método usado pelos alquimistas. Por extensão passou a tudo o que não é compreensível facilmente, à poesia medieval denominada trobar clus, isto é, escrever de tal modo que só os iniciados pudessem entender. Ver: BUENO, Silveira. Grande Dicionário Etilológico-prosódico da Língua Portuguesa. Apud: ANDRADE, F.C., A transparência do impossível: lírica e hermetismo na poesia brasileira atual. p. 50.

${ }^{5}$ Ibid., p. 24. É importante apontar a importância dos chamados poetas herméticos na formação intelectual de Pasolini. Ele leu ainda muito jovem as obras de Ungaretti - considerado um dos mais importantes representantes do hermetismo italiano - e todo o hermetismo italiano, formado a partir da perspectiva ungarettiana sobre poesia. Como consta na biografia sobre Pasolini, Pasolini, Biographie, em meados dos anos 40, Pasolini uni-se a alguns amigos, a fim de fundar uma revista literária, cujo conteúdo condensava "um programa poético " que deveria representar a continuidade da poesia clássica, filtrada através da poesia moderna de Ungaretti, Montale, Sereni ${ }^{5} . .$. ". Ver: NALDINI, N. Pasolini, p. 30.
} 
fazer uso do friulano como língua da poesia, não tentava igualar-se aos poetas herméticos, mas sim preservar a língua dialetal. Desde a institucionalização do italiano como língua nacional, os dialetos passavam por um processo de apagamento, caindo em desuso. Era comum não somente nas cidades, como também no interior, a substituição dos dialetos pelo idioma nacional.

No entanto, a influência da poesia hermética não se excluía completamente da vontade poética pasoliniana diante da língua dialetal. Dentre os poetas modernos, o que mais influenciou o estilo de Pasolini foi, sem dúvida, Giovanni Pascoli, poeta do século XIX, considerado também uma importante influência ao hermetismo. O contato de Pasolini com os poemas pascolianos se deu muito cedo, ainda na infância. A descrição que Pascoli imprime aos seus poemas sobre a relação dos homens com a natureza foi inspirador ao jovem poeta. A admiração pasoliniana pela poesia de Pascoli era tamanha, que em 1945, ele escreveu seu trabalho de conclusão do curso de Letras nela inspirado - Antologia della lírica pascoliana. Interessava nessa poesia aquilo que Pasolini denominou como uma "mistura de linguagens", ou seja, mistura de estilos e léxicos, tal como Dante Alighieri havia feito anos antes. Apesar de identificar uma inovação comedida na poesia de Pascoli, Pasolini reconhecia nela uma importante referência à atividade poética do século XX. De fato, o estilo pascoliano provocava as mais variadas opiniões, conforme será apontado no capítulo 2, principalmente pela estranheza que provocou nos seus críticos. Esse tom marginal, polêmico, também foi um importante fator de identificação com a poesia de Pasolini.

Ao final dos anos 40, Pasolini deu início a uma nova etapa de sua relação com a poesia dialetal. Em 1948, ele começou a escrever seus primeiros ensaios destinados à crítica poética, tendo como tema, sobretudo, a poesia dialetal. Esses textos estão reunidos no livro Passione e Ideologia, publicado em 1960 pela editora Garzanti. Os textos compilados nesse livro foram escritos ao longo de 10 anos para a publicação em diversos periódicos nos quais o autor era colaborador sobretudo em revistas literárias, tais como Officina - e Il stroligut e a introdução de dois livros anteriores: Poesia dialettale del Novecento (1952) e Canzoniere Italiano (1955). 
Nos anos de produção desses ensaios, Pasolini já havia desenvolvido suas ideias acerca da poesia dialetal italiana, fazendo uso de um conjunto de referências que justificariam o argumento central que norteia os ensaios reunidos no livro: a ideia de poesia dialetal como a poesia popular italiana. É nesse sentido que a pesquisa será desenvolvida, pensando a poesia dialetal italiana a partir de um conjunto de referenciais dos quais Pasolini faz uso no livro. Tal atitude corrobora sua hipótese de que esta é a poesia popular na Itália por excelência. Com isso, cabe aqui uma apresentação da estrutura do texto.

Pode-se dividir Passione e Ideologia em duas partes distintas, que, apesar de não terem sido escritas como uma mesma obra, complementam-se, na medida em que sustentam o argumento de Pasolini em torno de sua ideia central ao pensar na poesia dialetal italiana. A primeira parte, intitulada Due studi Panoramici é dividida, por sua vez, em duas seções: La poesia dialettale del Nocecento e La poesia popolare italiana. Como já foi informado, esses textos constituem a introdução de outros dois livros anteriores que Pasolini já havia publicado. A segunda parte, intitulada Dal Pascoli ai neo-sperimentali, parte de uma leitura sobre o estilo poético do poeta Giovanni Pascoli e suas possíveis influências ao poetas italianos posteriores. Pode-se afirmar, assim, que esse livro reúne ensaios que constituem o resultado das reflexões de Paoslini sobre poesia na Itália até aquele momento.

Sobre a primeira parte do livro, a primeira seção, Poesia dialettale del Novecento é composta por quatro ensaios, nos quais Pasolini definia a poesia dialetal como fruto de uma "paixão romântica", típica da primeira fase do romantismo italiano, pautada pelo cancioneirismo e pelo folclore. Para ele, o romantismo italiano em sua primeira fase - quando a palavra "popular" ainda não havia adquirido uma "consciência social" que caracterizaria a poesia do século XX - possuía a preocupação em cantar os sentimentos do poeta, sobretudo o amor. O movimento romântico, ainda segundo Pasolini, foi fundamental ao desenvolvimento de uma ideia de realismo dentro da literatura e da poesia dialetal. A matriz do pensamento romântico, ainda de acordo com o texto, teria germinado em Vico através de uma concepção de poesia ("racionalidade poética") como a primeira linguagem por excelência, sendo esta proveniente da fantasia. 
Nos ensaios que compõem a segunda seção, La poesia popolare italiana, Pasolini discute questões relativas ao desenvolvimento de uma noção de "poesia popular", com especial destaque para a interpretação romântica a partir do século XIX. Tal noção teria se desenvolvido através do trabalho de estudiosos como Niccòlo Tommaseo, Nigra e Alessandro D’Ancona, a partir do recolhimento dos cantos populares ${ }^{6}$. A interpretação romântica sobre poesia popular surgiu, segundo Pasolini, de uma ideia de povo, identificada com os critérios de "originalidade" poética. Assim, para ele, a poesia popular assumiu o sentido de "única poesia", construída através de uma "criação coletiva".

Na segunda parte de Passione e Ideologia, Pasolini analisa o trabalho do poeta Giovanni Pascoli, que, segundo sua leitura, teria fornecido ao século XX um modelo de literato. Nesses ensaios, a poesia de Pascoli é pensada dentro de uma tradição poética cujo percussor seria Dante Alighieri e sua Divina Comédia. O elemento central dessa tradição seria a poesia plurilinguista, pautada na "mistura de linguagens", e que Pasolini entende ser um dos itens que caracteriza a poética dantesca como realista. A obra canônica de Dante, por sua vez, foi considerada pelo ensaísta como a "mais realista das obras poéticas italianas"7 . Desse modo, essa tradição que Pasolini constrói em torno de uma ideia de poesia plurilinguista como poesia realista, tendo como percursor Dante, chegando até o século XIX com Pascoli, seria uma maneira, dentro de sua retórica, de incluir sua poesia nessa mesma tradição. Tal é uma das hipóteses norteadoras dessa dissertação.

A leitura dessas referências foi mediada, sobretudo, por dois importantes críticos italianos, Benedetto Croce e Gianfrando Contini. Com isso, é fundamental compreender os ensaios de Passione e Ideologia a partir do conjunto de pensadores e movimentos intelectuais que foram mobilizados pelo autor, sem os quais os textos não existiriam. Pasolini constrói um raciocínio complexo, mediado por muitas referências. No entanto, é enganoso pensar que nesses ensaios Pasolini

\footnotetext{
${ }^{6}$ Niccòlo Tommaseo (1802-1874) foi um importante linguista italiano, sendo um dos responsáveis pela elaboração do Dizonário della Lingua Italiana. Constantino Nigra (1828-1907) foi um diplomata, estadista e, sobreduto, um poeta e filólogo italiano. Dedicou-se ao estudo sobre os cantos populares da região de Piemonte. Já o poeta e filólogo Alessandro D’Ancona (1835-1914) constitui uma das referências de Pasolini de um intelectual dedicado ao estudo da cultura popular. Recolheu cantos populares da região da Sicília e Toscana. Além disso, também dedicou ao estudo sobre Dante, através da análise de Vita Nuova, Commedia e Convivio. Ver: http://www.treccani.it/enciclopedia.

7 "più realistica delle opere poetiche italiane". [Tradução Livre]. (PASOLINI, P. P., Il Reame. In: Passione e Ideologia, p. 12).
} 
é um mero debatedor das ideias alheias. É característica inerente aos textos o uso pelo autor das referências de maneira livre, não ficando claro se Pasolini quer encaixá-las dentro de um argumento pré-estabelecido. Não há dúvidas de que ele leu tudo aquilo que cita, mas em muitos momentos sua interpretação contradiz os textos lidos. Um exemplo disso é a análise que fez do ensaio Preliminari sulla língua del Petrarca, de Gianfranco Contini. Cotejando sua leitura com aquilo que consta no ensaio, é possível perceber como ele não explorou devidamente o cerne do argumento de Contini: problematizar a distinção entre a poesia de Petrarca e Dante a partir de uma ideia de monolinguismo e pluriliguismo.

Diante do que foi levantado até aqui, a dissertação foi organizada em 3 capítulos, pensando na relação de Pasolini com essas referências à sua ideia de poesia e fechando a análise com uma breve apresentação sobre como a relação de seus estudos sobre poesia dialetal italiana influenciaram sua atividade ensaística posterior.

O primeiro capítulo, intitulado As referências teóricas de Pasolini: de Vico a Croce, procurou realizar uma análise dos teóricos que foram identificados como fundamentais à formação da ideia de poesia dialetal pasoliniana. A ideia defendida no capítulo é a de que o ensaio de Croce, intitulado Poesia popolare $e$ poesia d'arte (1929) será imprescindível para que Pasolini construa sua ideia de poesia popular na Itália, e que ele defendia ser a poesia dialetal ${ }^{8}$. Mesmo opondose a muitas ideias que Croce expôs no seu texto, Pasolini afirma ser esse ensaio o mais completo estudo sobre o folclore italiano do século XIX na Itália, não podendo ser ignorado. Foi a partir dos teóricos e das questões trabalhados no ensaio croceano que Pasolini pôde desenvolver sua problematização acerca da dita poesia popular na Itália. Para tal intento, tanto ele quanto Croce mobilizaram um conjunto de referências, tais como Vico, Rousseau, Herder e, por fim, o pensamento romântico em Schlegel e Schelling e suas possíveis influências ao tardio romantismo na Itália. A última parte do capítulo apresenta as conclusões de Pasolini sobre os assuntos que foram discutidos por esses pensadores.

No segundo capítulo, As referências poéticas de Pasolini: de Dante a Contini, a análise procurou concentrar-se na questão da poesia plurilinguista, a

\footnotetext{
${ }^{8}$ CROCE, B., Poesia popolare e poesia d'arte. Publicada em: La crítica. Rivista di Letteratura, Storia e Filosofia diretta da B. Croce, p. 321.
} 
partir da ideia de uma "mistura de linguagens" (mistura de léxico e estilo), cujo o percursor seria Dante Alighieri. A leitura que Pasolini faz desse tema é mediado pelo ensaio do crítico Gianfranco Contini, Preliminari sulla língua del Petrarca $(1951)^{9}$. Interessava a Pasolini a distinção apontada por Contini de que a poesia de Dante era plurilinguista, em oposição àquela de Petrarca, que seria monolinguista. A hipótese defendida aqui neste trabalho é a de que a intenção de Pasolini era forjar uma tradição da poesia plurilingista, da qual também fariam parte Giovanni Pascoli, além dele próprio. O capítulo se inicia com a apresentação dessa hipótese. Em seguida é apresentada a leitura do tratado dantiano De Vulgari Eloquentia, em que Dante defende a composição da poesia em língua vernácula no estilo sublime (dando origem ao chamado "vulgar ilustre"). O plurilinguismo fazia parte daquilo que Pasolini definia como sendo o realismo dantiano, e que teria inspirado a sua própria ideia de poesia realista. Em seguida são analisados ensaios de Benedetto Croce sobre Dante (La poesia di Dante) e Pascoli (Giovanni Pascoli, studio critico). Em seguida, são discutidos os ensaios de Gianfranco Contini. O capítulo é encerrado com a leitura de Pasolini acerca dos temas levantados por esses autores.

O terceiro capítulo é, na verdade, uma extensão daquilo que foi debatido nos capítulos precedentes. Se em sua juventude os ensaios pasolinianos dedicavam-se principalmente à poesia, ao final dos anos 50 ele passa a dar maior ênfase a outros aspectos da linguagem, pensando, acima de tudo, na linguagem cotidiana. A hipótese defendida é a de que suas ideias acerca da linguagem foram moldadas pela sua formação em torno da poesia popular (dialetal) italiana. Este capítulo mostra como, a partir dos anos 50, a Itália sofreu um processo de mutação linguística, em função do processo de industrialização que se acentuava no país e do vocabulário inerente à linguagem televisava. O resultado desse processo teria sido o surgimento de uma "língua tecnológica", que, para Pasolini, seria o reflexo de uma cultura de massa que se construía oprimindo a linguagem popular natural da Itália, ou seja, a linguagem dialetal. Nesse sentido, a análise do capítulo pensou essas questões a partir da querela entre Pasolini e Calvino: o

\footnotetext{
${ }^{9}$ CONTINI, G, Preliminari sulla lingua del Petrarca. In: Varianti e altra linguística: uma raccolta di saggi.
} 
primeiro sendo contrário às transformações linguísticas, enquanto Calvino enxergava essas mudanças positivamente. Um outro tema que faz parte da contenda entre eles foram as críticas que Pasolini fez à tradução das fábulas italianas por Calvino, que foram compiladas no livro Fábulas Italianas. 


\section{As referências teóricas de Pier Paolo Pasolini: de Vico a Croce}

A partir do que foi exposto na Introdução, é possível perceber que a experiência de Pier Paolo Pasolini em sua estadia em Casarsa, região de Friuli, norteou sua relação com as línguas dialetais, nas quais ele identificou uma autenticidade e originalidade próxima a uma concepção de língua fruto do "espírito do povo", decorrente, por sua vez, da relação entre os homens e a natureza, tal como valorizavam os românticos - como Schlegel e Schelling - em seus estudos. Com isso, ele tomou como referências diversos pensadores e movimentos literários que trataram da questão da linguagem, sendo que o elemento em comum entre eles era a valorização da chamada "poesia primitiva". Para esses pensadores, a poesia era a "língua original", vinculada à construção de um sentido à existência, a um modo de interpretação da natureza e uma forma de interpretação religiosa e filosófica.

Entre as principais influências de Pasolini, destacam-se aqueles que contribuíram ao desenvolvimento de seus ensaios de crítica poética coligidos em Passione e Ideologia (cuja primeira edição foi publicada em 1960), tais como Giambattista Vico, Rousseau, Herder e o movimento romântico, tanto na região da Alemanha, quanto o tardio romantismo na Itália. Todas essas referências foram lidas por Pasolini através da mediação de Benedetto Croce, que em seu ensaio Poesia popolare e poesia d'arte (de 1929), faz uma leitura da poesia romântica italiana do século XIX. Assim, seguindo os passos de Croce, Pasolini traçou sua argumentação em torno da análise de uma bibliografia que valoriza aspectos históricos e apresenta uma visão da linguagem que vincula a poesia a uma ordem natural, fugindo de concepções supostamente artificiais de composição poética. Através desses nomes, Pasolini tencionava, assim, opor-se às regras de composição poética de seu tempo, valorizando a poesia dialetal italiana.

Na Ciência Nova de Vico, a interpretação de Pasolini valorizou a noção da poesia como linguagem entre os primeiros homens, sendo ela a forma primitiva de dar sentido a uma realidade que era vinculada à natureza. Através da linguagem, 
segundo Vico, os homens teriam criado seus primeiros mitos, aos quais podia-se associar as primeiras noções de entendimento do mundo. Por uma associação entre Vico e o ensaio de Rousseau, Ensaio sobre a origem das línguas, a leitura pasoliniana procura demonstrar de que modo a construção dos argumentos do filósofo francês também defende a poesia como primeira forma de comunicação, estando ela associada a um processo de "socialização primitiva". Esses dois autores teriam, portanto, influenciado uma determinada concepção romântica de poesia, tal como Pasolini expressou em Un secolo di studi sulla poesia popolare, em que ele resume as principais referências identificadas como fundamentais à discussão sobre poesia popular desenvolvida por ele em seus ensaios:

(...) é evidente que já em Vico ou em Rousseau germinavam certas noções, embora puramente expressas, que se desenvolveram na paixão romântica pela poesia primitiva: implica um regresso no falante auditivo como specimen de uma idealizada coletividade, e em seguida coincide com a descoberta, tão cheia de futuro, da nação, em sentido étnico e patriótico primeiro, e em seguida, no sentido socialista ${ }^{10}$.

Portanto, quanto ao romantismo, Pasolini aponta o movimento romântico iniciado no século XVIII na região da Alemanha como fundamental à construção de uma ideia de poesia popular. São esses os pensadores e movimentos eleitos por Pasolini para iniciar seus estudos sobre poesia popular na Itália e dar origem aos ensaios que constituem a primeira parte de Passione e Ideologia, cujo elemento em comum é a construção da ideia de poesia popular na Itália como a poesia dialetal. Desse modo, nesse capítulo serão analisados, inicialmente, Vico e Rousseau. Em seguida, as ideias de Herder e de alguns pensadores do Romantismo alemão para, enfim, chegar ao século $\mathrm{XX}$, com os ensaios de Benedetto Croce e a conclusão com a análise pasoliniana. Através de cada um desses pensadores ou movimentos, pretende-se analisar de que maneira a noção de poesia popular foi sendo construída e de que forma ela desembocou na Itália (e na obra de Pasolini) em uma noção de poesia dialetal. Presume-se, neste capítulo,

\footnotetext{
10 " E evidente che già nel Vico o nel Rousseau germinano certe nozioni, sai purê appena espresse, Che si svilupperanno nella passione alto-romantica per la poesia primitiva: implicante um regresso nel parlante udito comme specimen di um ídealizzata collettività, e quindi coincidente com la scoperta, cosi densa di futuro della "nazione", in senso étnico e patriottico prima, in senso socialistico poi" (PASOLINI, P. P., Un secolo di studi sulla poesia popolare. In: Passione e Ideologia, p. 141).
} 
que Pasolini teria construído tal noção de poesia justamente a partir da leitura que fez dessas referências, de forma a corroborar suas ideias.

\subsection{A poesia primitiva em Vico: antecedentes de uma ideia de poesia popular}

$\mathrm{Na}$ construção de seus argumentos, Pasolini colocou Vico ao lado de Rousseau como um importante percussor da ideia de poesia primitiva, que, de acordo com ele, teria desembocado, no século XIX, na filosofia romântica. Pasolini seguia os passos dados por Benedetto Croce, que defendia a influência direta do pensador napolitano nas concepções construídas pelos românticos. Em Vico o que mais diretamente interessa a Pasolini é a sua defesa de uma poesia que não emana de um trabalho meticuloso do intelecto, mas de uma necessidade quase física entre os primeiros homens de se relacionarem com a natureza que os cercavam. Assim, a origem natural da poesia dada por Vico contribuiria com os argumentos pasolinianos em favor de uma poesia menos acadêmica e "artificial" como a que, ainda segundo ele, estava em voga nas academias italianas de seu tempo.

Muitos elementos se misturam na ciência que Vico queria criar e informar: das noções bíblicas a uma noção pagã de língua, bem como de história, além da defesa do surgimento da filosofia como algo intrínseco ao surgimento da filologia. Mais que uma idéia de linguagem, há nessa ciência a necessidade de estabelecer uma noção de história e vinculá-la à interpretação de uma língua que se forma no tempo junto com os homens. Mas, de que modo esses elementos se relacionam? E de que maneira a ciência viquiana pode ter sido antecessora de uma idéia de "povo" e de "linguagem popular" entre os românticos do século XVIII alemão e no tardio romantismo italiano, tal como Croce e por sua vez Pasolini a interpretaram?

Vico, segundo seu estudioso e tradutor Marco Lucchesi, optava por um caminho contrário ao do "estudo dos sistemas", defendido pelo principal opositor viquiano, René Descartes ${ }^{11}$. Lucchesi defende que as ideias cartesianas eram vagas, pois só ofereceriam uma interpretação abstrata da natureza. O motivo para

\footnotetext{
${ }^{11}$ VICO, G., Ciência Nova, p. 14.
} 
esta afirmativa era simples: o homem só poderia obter a verdade mediante o conhecimento, e este só poderia ser obtido sobre aquilo que é obra humana. A busca pelo conhecimento das coisas do mundo se tornou incessante, mas, para Vico (na leitura do tradutor), nem todas as ciências ofereceriam o conhecimento verdadeiro $^{12}$. O homem só poderia conhecer verdadeiramente aquilo que era construção da humanidade, o que não era o caso do mundo natural. A história, por outro lado, seria obra humana e por isso, seu objeto de conhecimento. Vico fundou uma teoria que se opôs ao programa cartesiano através do desenvolvimento de um conjunto de ideias que estabeleciam a origem dos homens através de uma racionalidade poética, fundada sob mitos e fábulas.

O método viquiano se edifica em dois pilares fundamentais: a filologia e a filosofia. No presente trabalho a estrutura filológica que Vico estabeleceu é a que mais interessa. $\mathrm{O}$ que Vico entendeu por linguagem compreendia também um sistema de sociabilidade inerente aos homens, que incluía "as religiões, matrimônios, instituições" ${ }^{13}$. A primeira linguagem, derivada de uma sabedoria poética, nada mais era que fruto do desenvolvimento de uma metafísica sentida, imaginada e repleta de fantasia. Vico definiu a poética como a relação mítica do homem com seu corpo e com a natureza. Desse modo,

(...) devemos, em vista de tudo isso, dar início à sabedoria poética, a partir de uma tosca metafísica própria, da qual como que de um tronco, se espalham ao longo de um ramo, a lógica, a moral, a econômica e a política, todas poéticas; (...) E com esclarecidas e distintas formas havemos de mostrar como os fundadores da humanidade gentílica, com a sua teologia natural (ou seja, metafísica),

\footnotetext{
12 Segundo Noam Chomsky, a questão da linguagem em Descartes fazia parte de sua ampla discussão sobre seus estudos, que ultrapassaram a explicação mecânica aos limites da Física à Fisiologia e à Psicologia. Descartes, segundo Chomsky "chegou a conclusão de que o homem possui faculdades exclusivas, que não podem ser explicadas em bases puramente mecanicistas (...) A diferença essencial entre o homem e o animal fica mais claro na linguagem humana, em particular na capacidade humana de formar novas proposições, que exprimem novos pensamentos (...)". Assim, o pensador francês, concluiu que além do corpo, era necessário incluir em sua análise um espírito, "substância cuja essência é o pensamento - aos outros seres humanos". Para confirmar sua leitura, Chomsky cita as conclusões de Descartes, expressas em correspondência a um amigo: "não há nenhuma de nossas ações externas que assegure aos que as examinam que nosso corpo seja algo mais que uma máquina que se mova em si mesma, mas que tem em si também um espírito que pensa, exceto as palavras ou outros sinais efetuados com relação a quaisquer objetos que se apresentam, sem referência a alguma paixão". Ou seja, em sua explicação acerca da linguagem, Descartes não exclui a explicação mecanicista, mas inclui em sua análise, o elemento do espírito, que movido a paixões, torna o homem, principalmente associado à linguagem, distinto dos animais. Ver: CHOMSKY, N. A linguagem cartesiana, p.13-15.

${ }^{13}$ VICO, G., op. cit., p. 16.
} 
imaginaram seus deuses; com a lógica inventaram suas línguas, com a moral, criaram seus heróis; com a econômica, fundaram suas famílias $(. . .)^{14}$.

Assim, a sabedoria poética deu origem à metafísica dos gentios (ou gigantes), usada pelos homens, fundada na relação destes com as divindades e que deu origem, através da fantasia, às coisas do mundo, tal como as instituições, os ritos e a linguagem. Todas elas poéticas (míticas). Nessa criação proveniente da imaginação, os homens estabeleciam uma lógica poética, a sua lógica de entendimento do mundo (do verum). Essa relação entre os homens e o mundo, a lógica estabelecida por eles para lidar com o mundo natural levava-os, conforme à curiosidade pelos elementos da natureza (como os trovões do céu), a buscarem explicações para os fenômenos naturais. Motivados por essa curiosidade, os gentios faziam uso dos sentidos provenientes do vulgo extremamente vinculados aos corpos e suas mentes estavam imersas nos sentidos. Nessa relação entre o mundo natural e a invenção da linguagem, ocuparam um papel muito importante os poetas teólogos, ou sábios, aqueles que "adivinhavam" e interpretavam os deuses (princípio da divinação), originando, pois, uma ideia de poesia. Tal ideia de poesia, para Vico, seria uma forma conatural, inicialmente divina, pois os homens acreditavam que encontrariam algum sentido nas coisas no mundo justamente nas divindades. A poesia não seria produto individual, mas fruto da coletividade. Sua origem estaria vinculada à religião, que, como elemento fantasioso, permitia imaginar o mundo através da atividade dos poetas (sábios teólogos), pois "em nenhum outro lugar, melhor se exercitaram ao cantar o prodígio das magas realizado por encantamentos". Assim, Vico concluiu que

por defeito de humano raciocínio, nasceu a poesia, de modo tão sublime que das filosofias que vieram em seguida, artes e poéticas, e críticas, não se originou outra igual ou maior (...) Em virtude da descoberta dos princípios da poesia, dirimiu-se a opinião da sabedoria inatingível dos antigos, que tanto se desejava descobrir, de Platão a Bacon, de Verulamio, De sapientia veterum, a qual foi a sabedoria vulgar dos legisladores que fundaram o gênero ${ }^{15}$.

\footnotetext{
${ }^{14}$ Ibid., p. 148.

${ }^{15}$ A distinção entre antigos e modernos, na acepção de Jacques le Goff, desenvolveu-se num contexto equívoco e complexo. Em primeiro lugar, porque cada um dos termos e conceitos correspondentes nem sempre se opuseram um ao outro: 'antigo' pode ser substituído por 'tradicional' e moderno por 'recente' ou 'novo' e, em seguida, porque qualquer um dos dois pode ser acompanhado de conotações laudatórias, pejorativas ou neutras”. Há também o problema do
} 
A sabedoria poética contribuiu para a constituição de um conjunto de significações e instituições, através da atuação dos poetas teólogos e a metafísica dos gentios, pois tornou-se uma lógica poética, cujo significado primeiro era o de fábula (definida por Vico como gênero fantástico), e o sentido original era o de vera narratio, ou, falar verdadeiro ${ }^{16}$. A verdade dos homens naquele tempo encontrava-se vinculada às divindades, criadoras do mundo natural.

Os homens, através da atividade dos poetas sábios, foram conferindo definições e sentidos às coisas do mundo. Deste modo, desaparece neles a imaginação fabulosa ou sabedoria poética. Ao mesmo tempo, a humanidade foi se desenvolvendo e se dispersando para diversas localidades. Os elementos naturais foram sendo nomeados, conferindo outro tipo de sentido ao mundo e, consequentemente, tolhendo a imaginação poética. As palavras passaram a variar de acordo com a região em função do clima e da vegetação, mas, salienta Vico que,

(...) com identidade, não de proporção, mas, para falar à maneira escolástica, de predicabilidade, aquelas significam as diversas espécies ou os diversos indivíduos (...) tanto que devem ter uma significação unívoca, compreendendo uma razão comum à sua espécie ou indivíduos; de modo que tais alegorias devem ser as etimologias dos falares poéticos, que lhe deram origens unívocas, como das falas vulgares são as mais frequentemente análogas ${ }^{17}$.

Se os homens foram construindo sua linguagem ao longo do tempo, qual era a língua falada por Adão, já que ele, então, tinha o poder de dar nomes às coisas? Ao tratar da lógica poética, Vico estabelece essa diferença, entre o falar do primeiro homem e aquele dos poetas teólogos:

tipo de relação que o "moderno" estabelece com o "antigo", que pode ser de oposição ao mesmo uma relação temporal. Portanto, a partir da leitura que Le Goff, percebe-se como essa oposição deve ser relativizada. Em Vico, por sua vez, é possível perceber que sua interpretação questiona a tendência de seu tempo em tomar os princípios da Antiguidade Clássica como as únicas referências poéticas possíveis. Humano. Ver: GOFF, J. História e Memória, p. 149-152. Ver também: VICO, G. Ciência Nova, p. 158.

${ }^{16}$ Ibid., p. 167-169.

${ }^{17}$ Ibid., p. 169 e 190. 
Porque tal primeiro falar, que foi o dos poetas teólogos, não foi um falar segundo a natureza dessas coisas (como deve ter sido a língua sagrada criada por Adão, a quem Deus concedeu a divina onomathesia, ou seja, a imposição dos nomes às coisas, segundo a natureza de cada uma), mas um falar fantástico por substâncias animadas, a maior parte delas imaginadas divinas ${ }^{18}$.

A teoria da linguagem em Vico como fruto da imaginação humana coloca a língua adâmica, onomathesia como antecessora daquela desenvolvida pelos poetas sábios. O ponto de ruptura entre essas linguagens não é claramente explicado na Ciência Nova, mas se refere ao episódio bíblico da criação de falares distintos, como castigo divino entre os homens envolvidos na construção da Torre de Babel $^{19}$. Ao informar sobre a formação de novas línguas, Vico esclarece tal contradição conciliando os textos sagrados à sua teoria de fundação de uma linguagem construída e constituinte dos homens e da história:

(...)o que se deve entender das línguas dos povos do Oriente, entre os quais Sem, que propagou o gênero humano. Mas, com as restantes nações do mundo, outras devem ter sido as necessidades. Pois que as raças de Cam e Jafé tiveram de se perder pela grande selva da terra com error ferino(...); e assim, errantes e sós, tiveram de gerar filhos, com uma ferina educação, desnudos de todo o humano costume e privados de toda a humana fala, e, portanto, num estado de brutos animais. E tanto tempo decorreu para que a terra, seca da umidade do universal dilúvio pudesse produzir exalações secas para que se gerassem os raios $(\ldots)^{20}$.

Pode-se entender, desse modo, que o regresso humano a uma bestialidade poética teria conduzido os homens a um novo caminho que posteriormente culminaria no desenvolvimento das nações, capazes de produzir, por exemplo, um Homero, um Dante Alighieri e um Vico, que, por sua vez, forneceu um conjunto

\footnotetext{
${ }^{18}$ Ibid., p. 168.

${ }^{19}$ A leitura de Paolo Rossi, por exemplo, mostra como uma fortuna crítica do pensador napolitano considerava a ideia de uma língua que se constrói na história junto com o desenvolvimento dos homens, divergindo da ideia de língua natural, adâmica. Quando Vico atribuiu a variedade das línguas aos descendentes de Noé, após o dilúvio, que se dispersaram para outras regiões e daí teria início a variação linguística, conforme as diferentes regiões e climas, há uma clara discordância com os textos sagrados, sendo que, na Ciência Nova, a Providência Divina é frequentemente mencionada. Ver: ROSSI, Paolo. Sinais do tempo: história da Terra e história das nações de Hooke a Vico. São Paulo: Companhia das Letras, 1992.
}

20. VICO, G., Ciência Nova, p. 67-68. 
de conceitos que teriam servido de inspiração para o desenvolvimento do préRomantismo, com Goethe, Sturm und Drang e Herder ${ }^{21}$.

\subsection{Rousseau: as línguas e a necessidade de socialização entre os homens}

Assim como Pasolini já havia apresentado, há uma interseção entre as ideias já expostas em Vico e as que serão tratadas nesse subcapítulo acerca da origem das línguas em Jean-Jacques Rousseau. Ambos os autores se dedicaram a estudar a origem das primeiras linguagens, atribuindo a elas o desenvolvimento das primeiras filosofias. O processo de historicidade sofrido pelas línguas também é problematizado por Rousseau. Desse modo, os elementos da linguagem de Rousseau serão aqui apontados, de modo a compreender o que a interpretação de Pasolini sobre a obra de Croce permitiu-lhe atribuir a relevância desses autores aos estudos românticos.

Rousseau parece construir seu argumento com o objetivo de problematizar a questão da musicalidade entre os homens de seu tempo, e, para tal, o autor analisa o surgimento dos sons e das falas entre os primeiros homens. Identifica a origem das palavras como estando atrelada a uma necessidade de socialização, visto que a identifica como a " primeira instituição social”, pois ampliaria a capacidade de comunicação. As primeiras palavras foram resultado de uma construção natural, produto dos instintos, precedendo, portanto, o raciocínio. Desse modo,

Pode-se, pois, crer que as necessidades ditam os primeiros gestos e que as paixões arrancam as primeiras vozes (...). Essas línguas nada possuem de metódico e raciocinado; são vivas e figuradas. Apresentam-nos a linguagem dos primeiros homens como línguas de geômetras e verificamos que são línguas de poetas ${ }^{22}$.

A poesia é considerada por Rousseau como sendo a primeira linguagem entre os homens e construída a partir de um sentido figurado decorrente das

\footnotetext{
${ }^{21}$. Ver: STAROBINSKI, J., Jean-Jacques Rousseau: a transparência e o obstáculo; seguido de Sete ensaios sobre Rousseau, p. 420.

${ }^{22}$ ROUSSEAU, J. J., Ensaio sobre a origem das línguas, p. 265.
} 
primeiras impressões diante da natureza. A língua era marcada também por um tom natural, inerente à fisiologia humana, o que contribuiu para a formação das primeiras palavras em ritmo de canção. Tal aspecto é melhor desenvolvido por ele no capítulo XII em que, complementando a afirmativa acima mencionada, conclui,

Assim, com as sílabas nascem a cadência e os sons; (...) desse modo, os versos, os cantos e a palavra têm origem comum (...) os primeiros discursos constituíram as primeiras canções; as repetições periódicas e medidas do ritmo e as inflexões melodiosas dos acentos deram nascimento com a língua, à poesia e à música, ou melhor: tudo isso não passava da própria língua naqueles felizes climas e encantadores tempos $(\ldots)^{23}$.

Dessa maneira, Rousseau aproxima-se da interpretação viquiana, tal como Pasolini sugere. A primeira língua falada não era divina, tampouco decorrente do raciocínio, mas fruto da sensação e da experiência perante a natureza. A principal diferença entre os dois pensadores é que, enquanto Vico evidencia o surgimento das primeiras palavras como resultado de uma relação entre os homens e os deuses, a origem das línguas é pensada por Rousseau como derivada das paixões, ou daquilo que ele define como "moral", já que a interpretação rousseauniana pensa a língua pelo seu viés social. A menção aos aspectos religiosos em Rousseau somente acontecerá posteriormente, no capítulo XI de seu Ensaio, quando o autor cita, por exemplo, passagens da Bíblia, afirmando, "Adão falava, Noé falava - ou seja. Adão foi instruído pelo próprio Deus" ${ }^{24}$. Rousseau cita ainda a passagem bíblica acerca da Torre de Babel, mas parece vê-la mais como parte de uma tradição cultural do que um aspecto fundamental para se entender a origem das línguas. A relevância que ele atribuiu a Babel relaciona-se à dispersão das línguas após o castigo divino, mas, para ele, tal dispersão teria ocorrido independente da ação divina ${ }^{25}$.

Um de seus muitos comentadores, Jean Starobinski, construiu uma interpretação muito interessante acerca do filósofo francês e seus estudos sobre a origem das línguas. Starobinski considera fundamental a relação que Rousseau

\footnotetext{
${ }^{23}$ Ibid., p. 303.

${ }^{24}$ Ibid., p. 291.

${ }^{25}$ Ibid., p. 291.
} 
estabeleceu entre o homem e a sociedade para se pensar a questão da linguagem. Em Ensaio sobre a origem das línguas, o intérprete entende que o trabalho rousseauniano orientou-se no sentido de introduzir a história das sociedades dentro da história das linguagens, visto que para ele a sociabilidade teve início após o desenvolvimento da linguagem entre os homens:

(...) se admite que o homem de não sociável tornou-se sociável, é preciso igualmente conjecturar que o homem, de não falante tornou-se falante. Pois o homem não é originalmente dotado de palavra. A linguagem não é uma faculdade que o homem soube exercer de imediato: é uma aquisição, mas uma aquisição tornada possível por disposições presentes desde a origem e por muito tempo inexploradas ${ }^{26}$.

Assim, para Rousseau a construção da linguagem seria inerente à construção do processo histórico entre os homens, o que permite aproximar a interpretação rousseauniana daquela desenvolvida por Vico alguns anos antes, que estabelecia o homem como produtor de sua história, pensando, principalmente, no papel da linguagem nesse processo. No entanto, as motivações que o pensador napolitano encontrou para o desenvolvimento das primeiras palavras difere das que Rousseau teria encontrado pois, enquanto o primeiro atribuía esse processo a um defeito humano somado à sua necessidade de relacionar-se com os elementos da natureza (atribuídos aos deuses), na obra do filósofo francês, segundo Starobinski, há um entendimento de que a perfectibilidade humana (cujo resultado seria a saída de seu estado primitivo) o fez desenvolver uma faculdade inerente ao seu estado de natureza.

Além disso, Starobinski defende a naturalidade da socialização em Rousseau, já que, se ela é inerente a uma faculdade natural humana, "a instituição social não deixa, então, de estar relacionada com a natureza" ${ }^{27}$. A linguagem do homem em seu estado natural ainda seria o reflexo de sua relação com a natureza, o que, de algum modo, reforçaria a proximidade de Rousseau com Vico. Ainda quanto à relação que Starobinski enxergou em Rousseau entre o desenvolvimento da linguagem e a relação do homem com natureza é de uma desproporção, já que, “ (...) o homem selvagem na situação do infans (...) contribui para privá-lo de

\footnotetext{
${ }^{26}$ STAROBINSKI, J., Jean-Jacques Rousseau: a transparência e o obstáculo; seguido de Sete ensaios sobre Rousseau, p. 410.

${ }^{27}$ Ibid., p. 410.
} 
palavra" ${ }^{28}$. Infans se refere à infância do homem em seu estágio primitivo, de contato com a natureza. Quanto mais o homem se afastava de sua infância, mais livre estava para desenvolver sua linguagem, pois mais próximo se encontrava do desenvolvimento de sua sociabilidade. A relação da palavra com a socialização, por sua vez, estabelece-se por uma relação de causa e efeito; enquanto não havia homem, não havia sociedade e vice-versa.

Não se pode afirmar, ao certo, que Vico e Rousseau fossem ambos, ou mesmo qualquer um deles, defensores das línguas primitivas, tal como era Pasolini. No entanto, não se pode negar uma mínima relação entre ambos, visto que fica evidente que eles fazem uso dos mesmos elementos de análise, mesmo que difiram no modo. O fato é que tais conexões pouco importam e Pasolini não afirma tal ligação. O fundamental seria dizer que a relação que Pasolini estabelece entre eles justifica seu próprio argumento em torno de uma ideia de poesia dialetal popular e estas sendo tão naturais quanto às línguas primitivas de que tratam Vico e Rousseau. A poesia dialetal como parte de uma cultura que surge do contato dos poetas dialetais com a natureza, tal como foram produzidas as primeiras poesias primitivas - é esse o elemento que justifica o uso dessas referências nos ensaios pasolinianos.

\subsection{Herder e a origem das línguas: as influências do movimento romântico}

O ambiente intelectual e social que permitiu o desenvolvimento do movimento pré-romântico, o Sturm und Drang (Tempestade e Ímpeto), caracterizou-se pela crítica literário-cultural da burguesia alemã aos valores propagados pela burguesia francesa do movimento iluminista. Os homens que participaram de tal movimento tentavam promover uma "emancipação das letras nacionais", fugindo da concepção racionalista da Ilustração, defendendo "a bancarrota da razão e do intelecto e proclamaram, de outro lado, o valor supremo dos impulsos e emoções, da intuição e da sensibilidade, do inconsciente e da inspiração do "gênio", contraposta à inteligência crítica do artista" ${ }^{29}$. Contra a

\footnotetext{
${ }^{28}$ Ibid. p. 414.

${ }^{29}$ ROSENFELD, A. (org.), Autores pré-românticos alemães. p. 42.
} 
valorização do racionalismo dos iluministas, os "revolucionários" alemães “(...) agruparam suas ideias em torno de uma revelação, da linguagem, da sociedade" 30 . Como definiu Gerd Bornheim, a “ordem, a virtude e a moral são substituídas pelo caos criativo, pela força do gênio pelas paixões vitais além de toda a medida" 31 . O gênio criador era para eles a expressão máxima de toda natureza, e o "arquétipo do grande homem, (...) do poeta dotado de força criadora" (tal como a natureza) ${ }^{32}$. Dessa forma, a Alemanha teria iniciado uma revolução burguesa em seu aspecto filosófico e artístico, enquanto a França tornou-se o símbolo de uma transformação burguesa em seu âmbito político. Assim, em meio a esse movimento burguês que pensava a realidade artística e filosoficamente, os préromânticos deram início a um movimento que buscava afastar-se de uma filosofia que eles entendiam como "triste e ateísta" 33 .

Entende-se aqui que a aproximação dos românticos com a cultura e, mais especificamente, com a poesia definida como popular, estava relacionada justamente a essa tentativa de romper com os padrões classicistas tradicionais de análise artística, que se baseavam, por sua vez, nos padrões determinados por Aristóteles, cujas regras, retirariam da arte aquilo que ela tinha de mais precioso, isto é, a sua ingenuidade e naturalidade. Os pré-românticos viam nessas características (que podem ser pensadas como certa forma de originalidade) uma idealização do mundo camponês que estava se perdendo em função das influências dos centros urbanos e da industrialização. A partir desse olhar sobre o mundo rural surgiu, então, uma alternativa aos que eram considerados os males da industrialização; era necessário preservar essa cultura rural. Dessa maneira, o saber do povo deu origem a uma ideia de folclore.

O Sturm und Drang teve como nomes mais comumente citados Goethe e Herder. Em Goethe surgiram os primeiros manifestos e pensamentos que constituíram as ideias do movimento. Para Walter Benjamin, “(...) na poesia lírica do jovem Goethe a inovação da forma através da canção popular está associada à grande libertação proveniente da Academia Pastoril de Göttingen" ${ }^{34}$. Tal

\footnotetext{
${ }^{30}$ BENJAMIN, W. "Goethe". In: Documentos de cultura, documentos de barbárie: escritos, p. 42

${ }^{31}$ BORNHEIM, G., Filosofia do Romantismo, In: GUINSBURG, J. (org.), O Romantismo, p. 82

${ }^{32}$ ROSENFELD, op. cit., p. 13.

${ }^{33}$ BENJAMIN, op. cit., p. 42.

${ }^{34}$ Ibid., p. 82.
} 
libertação da qual trata Benjamin pode ser entendida aqui como referente aos modelos de poesia convencionais, marcados por um conjunto de regras que limitavam o fazer poético e representavam uma subordinação da arte às regras de dominação social. Ou seja, a libertação também se refere a uma tentativa de romper com as regras de dominação que os camponeses sofriam. Era na arte que eles mantinham sua liberdade, sua naturalidade e, dentro dessa lógica de uma distinção entre o povo e aristocracia, autenticidade que os pré-românticos enxergavam nessa arte.

No entanto, foi com Johann Gottfried Herder que o movimento da “Tempestade e Ímpeto" ganhou uma concepção mais específica. A compilação de cantos populares organizada por ele e que deram origem à obra Vozes dos povos em canções é considerada o marco do movimento, influenciando, inclusive, a poesia goethiana ${ }^{35}$. Acerca da linguagem, Herder dedicará seu Tratado sobre a origem das línguas ao estudo do tema, partindo da questão colocada na Academia alemã em 1769: "Supondo-se que os homens fossem abandonados à suas faculdades naturais, seriam capazes de inventar a linguagem? E de que modo eles chegariam a inventá-la?" ${ }^{\prime 36}$.

Ele propõe em seu tratado uma série de indagações sobre a origem da linguagem humana, se seria ela era divina ou se era parte de um processo histórico que acompanhava desenvolvimento dos homens, tal como aparece em Vico ou em Rousseau. O que se percebe é que há nesse questionamento uma preocupação evidente dos homens do século XVIII com a questão da origem da linguagem humana. Afinal, seria ela social ou natural? De acordo com Herder, primeiramente, a linguagem deve ser pensada pela distinção entre os homens e os animais.

De acordo com leitura herderiana, os homens, assim como os animais, conseguiam captar os sons da natureza, mas, somente os primeiros eram capazes de transformar esses sons em linguagem, graças à possibilidade de reflexão. Nesse sentido, os sons foram dados pela natureza e os homens desenvolveram a

\footnotetext{
${ }^{35}$ PASOLINI, P.P. Un secolo di studi sulla poesia popolare. In: Passione e ideología, p. 141.

36 "En supposant les hommes abandonnés à leurs facultes naturelles, sont-ils en état d'inventer le langage? Et par quel moyen parviendront-ils à cette invention?" (PÉNISSON, P. in : HERDER, J.G., Traité sur l'origine de la langue, p. 16).
} 
linguagem conforme iam desenvolvendo suas habilidades vocais ${ }^{37}$. O autor valoriza também as habilidades fisiológicas humanas, que permitiram aos homens tal feito, funcionando como os instrumentos musicais que se diferenciariam uns dos outros por suas especificidades na emissão de sons. Percebe-se que, assim como em Vico, o desenvolvimento da linguagem é identificado por Herder como inerente ao processo histórico, pois ela evoluía concomitantemente às transformações fisiológicas e cognitivas dos homens.

A poesia em Herder era considerada como a linguagem mais natural e, assim, mais real, e encontrava-se entre aqueles homens que gozavam de maior liberdade, ou seja, encontravam-se mais afastados da modernização e das instituições sociais. As canções (poesias) dos povos mais "agrestes" estavam dotadas de maior liberdade por não serem escritas para serem lidas - limitadas ao papel - e sim vivenciadas. Nesse sentido, há nessa ideia poética uma admiração por aquela poesia praticada pelos ditos povos selvagens, que mais próximos estariam da língua natural e assim possuíam uma língua muito mais sentida que falada. É por isso, afirmou ele,

que comove o poder da arte poética daqueles tempos primitivos, em que a alma dos poetas, acostumada a falar e não a tagarelar, não escrevia, mas sim exprimia $\mathrm{e}$, mesmo escrevendo, soava em linguagem viva; daqueles tempos nos quais a alma do outro não lia, mas sim ouvia, e mesmo lendo sabia ver e ouvir, porque estava aberta a todos os indícios de expressão verdadeira e natural; daí é que provêm aqueles milagres realizados pela arte poética ${ }^{38}$.

Pedro Caldas, em sua dissertação de mestrado, apresenta uma leitura historicista acerca da obra de Herder, tendo como objetivo compreender os pressupostos da filosofia da história deste autor em sua juventude a partir de alguns de seus textos, incluindo o Ensaio sobre a origem das línguas. Para Caldas, Herder estabeleceu uma divisão clara das línguas no tempo, nomeando como diferença essencial entre o que ele definiu como "línguas primitivas" e as "línguas civilizadas". As primeiras seriam "linguagens da impressão, de sonoridades naturais", enquanto as segundas seriam "linguagens metafísicas". Tal distinção, longe de pretender hierarquizá-las, teria antes como objetivo marcar a

\footnotetext{
${ }^{37}$ Ibid., p.78-79.

${ }^{38}$ HERDER, J. G. Da terceira coleção de fragmentos. In: ROSENFELD, Anatol (org.). Autores pré-românticos alemães, p. 30.
} 
diferença entre elas, o que tornaria o homem moderno, civilizado, incapaz de compreender em essência a linguagem primitiva. Sobre isso, Caldas afirma:

Devemos ter em mente então, pelas descrições de Herder (...) que a linguagem se faz, sempre, enquanto uma experiência. Há juntamente ao elemento formal um outro que lhe confere sentido. Nada está evidente. Por detrás da formalização gramatical e da grafia da língua, há elementos mais fundamentais e inatingíveis ${ }^{39}$.

Essa distinção será importante para se pensar a origem das línguas. De acordo com Caldas, o questionamento da origem divina para Herder se explica em função da distinção entre homens e animais, visto que a necessidade de lidar com a natureza, torna-o apto a adequar-se ao meio ${ }^{40}$. Como nos animais, a capacidade de lidar com a natureza existiria graças ao instinto e, deste modo, não haveria necessidade de linguagem. Ou seja, não seria possível uma origem animal das línguas. Mas, e quanto à origem divina? Para Caldas, não haveria uma resposta definitiva para esse questionamento. Herder mesmo se contradiria quanto a essa afirmativa. Assim Caldas concluiu, apontando a impossibilidade de Herder confirmar se as línguas seriam uma dádiva divina ou não, pois somente Deus daria essa certeza aos homens.

Já a interpretação que Isaiah Berlin conferiu à doutrina da linguagem herderiana identificava pensamento e ação, ou seja, linguagem e atividade. Assim, a poesia seria exemplo maior de linguagem, pois ela era "entre os povos primitivos, mágica no seu caráter, e não a fria descrição da natureza ou de qualquer outra coisa; ela é a resposta para a ação dos heróis, caçadores, amantes; ela estimula e dirige". Deste modo, alegou Berlin,

Os grupos humanos, grandes e pequenos, são produto do clima, da geografia, das necessidades físicas e biológicas e outros fatores similares; eles estão formados unitariamente pelas tradições e memórias comuns, das quais o principal ela é a linguagem (...). Nela reside a totalidade do mundo (...) visto que pensar é usar símbolos, os homens pensam necessariamente utilizando palavras e outros símbolos, e suas atitudes diante da vida ${ }^{41}$.

${ }^{39}$ CALDAS, P.E. Teologia da história: o fundamento do historicismo em Johann Gottfried Herder, p. 38.

${ }^{40}$ Ibid., p. 49.

${ }^{41}$ BERLIN, I., Vico e Herder, p. 149, 154. 
Dessa forma, segundo Berlin, Herder consideraria que "as palavras e as ideias eram uma coisa só" ${ }^{42}$, ou seja, a construção da visão de mundo entre os homens deu-se em conjunto com a linguagem. A relação entre a natureza humana e a linguagem era outro elemento valorizado por ele, "tão natural quanto o fato de ser homem" ${ }^{43}$. Nesse sentido ele questiona uma interpretação comum em alguns autores de que a língua seria uma dádiva dada por Deus, visto que ela possui uma relação de mútua dependência com a atividade reflexiva. Se a linguagem tivesse sido dada aos homens eles não teriam sido capazes de compreender tal dádiva divina.

Além disso, a poesia, de acordo com Herder, seria entendida como obra de arte, visto que poderia gozar de naturalidade e liberdade através da ação de seu gênio criador (poeta). No ensaio Shakespeare (1773), Herder analisa o poeta inglês a partir de critérios como naturalidade e verdade, o que tornaria Shakespeare um exemplo de gênio criador. Tais critérios teriam influenciado profundamente a noção de poeta e poesia entre os românticos ${ }^{44}$.

Quanto à semelhança com noções já presentes em Vico e Rousseau, é inegável existirem elementos em comum com as desenvolvidas por Herder. Existe em ambos autores uma associação entre natureza e cultura nas peculiaridades de um povo. Não se sabe, porém, se os pensadores pré-românticos teriam lido Vico. Há, porém, uma convergência nesses autores em relação a uma ideia de poesia que mais a frente será lida por Croce. Ou, como informa Auerbach, existiriam

Princípios muito semelhantes (...) concebidos e publicados meio século antes de sua primeira manifestação pré-romântica por um erudito napolitano de idade avançada, Giambattista Vico em sua Scienza Nuova. O movimento do Sturn und Drang era especificamente nórdico: fora criado num ambiente de liberdade juvenil e promovido por um grupo de jovens ligados pelos mesmos sentimentos entusiásticos. Vico (...) tampouco exercia influencia considerável sobre os movimentos pré-romântico e romântico (...). Os poucos alemães que, na segunda metade do século XVIII, depararam com o livro e folhearam suas páginas, homens como Hamann, Friedrich H. Jacobi e Goethe, não conseguiram reconhecer sua importância(...) Herder não menciona sequer o nome dele(... $)^{45}$.

\footnotetext{
${ }^{42}$ Ibid., p. 150.

${ }^{43}$ Ibid., p. 151.

${ }^{44}$ Ver: WERLE, M.A., Winckelman, Lessing e Herder: estéticas do efeito?. In: Trans/Form/Ação. P. 19-50.

${ }^{45}$ AUERBACH, E., Vico e o historicismo estético. In: Ensaios de literatura ocidental, p. 345-346.
} 
Assim, segundo as afirmações de Pasolini, o movimento pré-romântico deixou como herança ao Romantismo alemão uma concepção de arte e filosofia que seria largamente explorada por nomes como Lessing, Schlegel e Schelling, e inspiraram movimentos românticos ao longo da Europa. No início do movimento, os românticos tomaram as contribuições de Herder e Goethe quanto a uma ideia de liberdade, relação com a natureza e, principalmente, de poesia, mas as moldaram segundo uma vontade de atuação em um cenário literário-filosófico de seu tempo ${ }^{46}$. De acordo com Pedro Duarte, ao analisar especificamente o grupo de Iena, considerado como o primeiro romantismo,

o significado da palavra "romântico" muda bastante. Refere-se, às vezes, ao cânone que passa por Dante, Cervantes e Shakespeare. Pode ser aplicada para falar da tradição medieval. Em outros momentos, seu sentido aproxima-se daquilo que é simplesmente moderno. Mas, em geral, predomina o significado daquilo que ainda precisa ser feito, da poesia que deve ser produzida. Só que, como anunciou Friedrich Schlegel, essa poesia romântica, longe de estar restrita à forma literária, "abrange tudo que seja poético, desde o sistema supremo da arte, que por sua vez contem em si muitos sistemas, até o suspiro, o beijo que a criança poetizante exala em canção sem artifício" ${ }^{47}$.

Outra importante análise sobre o romantismo é a da pesquisadora Andrea Werkema que em sua obra Macário, para tratar do movimento no Brasil, traça uma comparação entre os diversos tipos de romantismo. A autora afirma que, apesar de o romantismo de Iena apresentar muitas semelhanças com o Sturm und Drang, é preciso questionar o peso (ou a ênfase excessiva) dada às heranças de Goethe, Herder e Schiller sobre pensadores como Schlegel e Schelling, já que não se pode negar alguma autenticidade destes últimos se comparado ao movimento anterior. Um outro equívoco que a autora aponta é para o reducionismo da noção de romantismo como se este fosse transnacional, esquecendo das especificidades entre os grupos que constituem o movimento na Alemanha ${ }^{48}$.

Desse modo, podemos apontar que Pasolini, se não assegurou categoricamente a unicidade do romantismo, também não afirmou as peculiaridades dos movimentos, distinguindo somente o romantismo na Alemanha

\footnotetext{
${ }^{46}$ D'ANGELO. P. Apud. DUARTE, P., Estio do tempo: o amor entre a arte e a filosofia na origem do romantismo alemão, p. 40

${ }^{47}$ DUARTE, P. op. cit., p. 41.

${ }^{48}$ WERKEMA, A. S. Macário, ou do drama romântico em Álvares de Azevedo. p. 18-19.
} 
daquele que ocorreu na região italiana no século seguinte. Isso pode ser explicado por seu interesse ser menor em definir de maneira precisa os tipos de romantismo do que apontar para a influência de pensadores como Goethe e Herder no romantismo na Alemanha e, tardiamente, na Itália. Nesse caso, deve ser levado em conta o movimento no modo como ele se desenvolveu em Iena, a fim de entender os argumentos de Pasolini.

\subsection{A noção de poesia entre alguns românticos alemães}

No ensaio Il problema, Pasolini resume ao leitor algumas ideias acerca da construção de uma ideia de poesia popular. Segundo ele, "os românticos colocaram idealmente a origem da poesia popular em um indeterminado período proto-histórico, como produto coletivo de um povo entendido como ethos ou nação"49. A origem natural da poesia dita popular é pensada nesse trabalho como ponto de partida para Pasolini pensar a poesia dialetal italiana. Os aspectos naturais que envolvem tal ideia de poesia preconizada pelos românticos são, segundo a leitura pasoliniana, aquilo que permite a ele vinculá-la àquela ideia de poesia existente em Vico e em Dante, por exemplo. Desse modo, o Romantismo (sobretudo o alemão) será aqui problematizado a partir de suas possíveis influências ao romantismo italiano, sendo que a ideia de poesia popular se confundiu com a de poesia dialetal, tal como Pasolini argumentou. Essa análise concentrou-se naquilo que Schlegel e Schelling pensavam acerca da poesia popular.

Um primeiro desafio ao estudar a estética do romantismo alemão é tentar delimitar tudo que o envolve. O primeiro passo para isso consiste em definir minimamente as diretrizes básicas desse movimento, evitando afirmações categóricas - como a de definir o Sturm und Drang como antecessor direto do movimento romântico, em função de uma certa proximidade com o Grupo de Iena. Talvez esse seja o equívoco de Pasolini. Não havia uma homogeneidade entre os pensadores românticos alemães, sem contar os romantismos que surgiram em outras regiões, tais como a França, a Inglaterra a Itália. O romantismo que será apresentado nesse subcapítulo foi aquele pensado por Schlegel e Schelling,

\footnotetext{
${ }^{49}$ PASOLINI, P.P., Il problema. In: Passione e Ideologia, p. 168.
} 
buscando, assim, justificar a influência do Sturm und Drang no Romantismo alemão, e este, por sua vez, no Romantismo italiano.

Friedrich Schlegel entende a poesia como algo absoluto, sinônimo de unidade, infinidade, estando presente em todos os elementos da natureza, incluindo os homens, que possuem a poesia em sua essência. A poesia absoluta aparece na natureza em forma de fragmentos, dispersa entre a fauna, a flora e entre a humanidade. É essa condição que tornaria o homem incapaz de dar conta da essência do mundo e menos ainda da sua própria essência, disponível a ele apenas por meio de fragmentos. Ou seja, os homens são limitados em relação às coisas do mundo, incluindo eles próprios. Para Schlegel, a consciência dessa limitação seria o elemento motivador à produção artística, como parte de uma busca incessante por sua natureza mais profunda. Desse modo, define Schlegel:

Como (...) sua poesia é limitada, justamente porque é a sua, do mesmo modo a perspectiva que dela possui não tem como escapar à limitação. $\mathrm{E}$ isto o espírito não pode suportar, sem dúvida porque sabe, sem saber, que nenhum homem é apenas um homem, pois pode e deve ser, ao mesmo tempo, verdadeira e efetivamente toda a humanidade. Por isso o homem, seguro de que se irá reencontrar, volta-se sempre de novo para fora de si mesmo, para obter o complemento de sua mais funda natureza nas profundezas de outrem ${ }^{50}$.

A arte, de acordo com Schlegel, seria o único modo de o homem tentar expressar sua essência. Ela seria capaz de comunicar e aproximar o homem da humanidade, bem como da natureza, e esse movimento, mediado pela arte seria incessante, funcionaria como um processo de aprimoramento e, por isso

(...) o poeta não deve satisfazer-se com o legado, em obras duradouras, da expressão da poesia que lhe é inata e característica. Ele precisa almejar sempre uma ampliação de sua poesia e de sua visão da poesia, aproximá-las do mais alto que é possível na terra; assim, estará se esforçando para associar-se a grande todo da maneira mais definida, mais determinada $(. . .)^{51}$.

A partir da explicação de Schlegel, pode-se concluir que a razão de serem os homens sociáveis explica-se também pela necessidade inerente à essência humana de buscar a unidade, reunindo-se de modo a juntar os fragmentos, assim como o contato dos homens com a natureza é fundamental a essa busca incessante

\footnotetext{
${ }^{50}$ SCHLEGEL, F., Conversa sobre poesia e outros fragmentos. p. 30

${ }^{51}$ Ibid., p. 30.
} 
pelo todo. Com isso, voltavam-se os românticos aos males da vida urbana industrial, que afastavam os homens da natureza e também da sua relação natural com seus semelhantes e, assim, afastava-os do caminho da unidade. Por outro lado, se Schlegel entendia a arte como um caminho para se aproximar da poesia e tal vontade de aproximação como inerente aos homens, haveria em todos uma essência artística, principalmente a arte poética.

Um outro elemento importante na obra de Schlegel era sua valorização da arte poética e, principalmente, da poesia da Antiguidade. Em Conversa sobre poesia, quando a personagem Andrea se dedicou a ler um texto sobre as épocas da arte poética e ressalta a relação da atividade poética ao longo das Idades, afirma que

Ela é uma arte, e onde ainda não o foi, deve-se tornar, e onde passou a sê-lo, decerto desperta naqueles que verdadeiramente a ama uma forte ânsia de reconhecê-la, compreender o designo do mestre, conceber a natureza da obra, acompanhar o surgimento da escola, sua via de formação. (...) É essencialmente próprio toda arte associar-se ao cultivado, e por isto a história se eleva em retrospecto de gênero em gênero (...) sempre mais alto, de volta para a Antiguidade, até a primeira fonte original.

Para nós, os modernos, para a Europa, esta fonte se encontra na Grécia (...). Lá havia uma fonte incessante de poesia oniplasmável, um poderoso caudal de representação em que cada vida se derrama sobre a outra (...) assim como os sábios procuram na água o começo da natureza, a poesia mais antiga também se mostra em fluídas feições ${ }^{52}$.

De acordo com a leitura desta personagem, os antigos se mostravam mais próximos à concepção original de poesia, ou seja, da essência do absoluto e da unidade poética que posteriormente foram sendo corrompidas. Ainda de acordo com o texto lido por Andrea, "o todo repousa sobre o solo firme da poesia antiga, uno e indivisível, através da vida solene dos homens livres, através da força sagrada dos velhos deuses" 53 . Era justamente na antiguidade clássica que os poetas do romantismo iam buscar sua referência à arte poética. Daquele tempo os românticos herdaram a concepção de poesia como ação. No entanto, o fazer poético para os românticos afastava-se das regras que o ordenavam na Antiguidade, e no século XVIII eram valorizadas a liberdade e naturalidade inerentes ao conceito de poesia que ali se instaurava e, mais do que isso, incluía

\footnotetext{
${ }^{52}$ Ibid., p. 35 .
}

${ }^{53}$ Ibid., p. 36. 
toda a atividade humana, inclusive a filosofia e a arte. Poetizar significava também conhecer o mundo, como consequência do agir.

Nesse mesmo sentido Schelling colocava-se quanto ao fazer poético. Se este è inerente à ação dos homens no mundo, a poesia era a ação sublime, capaz de representar o finito em infinito ${ }^{54}$. Para esse filósofo, a poesia ofereceria um ideal de realismo fora do consenso da subjetividade. Segundo Cristiane Azevedo, Schelling nega a concepção alegórica dos mitos. Ele definiria o mito como a poesia Absoluta ${ }^{55}$,

O verdadeiro universo em si, imagem da vida e do maravilhoso caos na imaginação divina, ela mesma já poesia e, no entanto, por si novamente matéria e elemento da poesia. Ela (a mitologia) é o mundo e, por assim dizer, o solo unicamente no qual podem medrar e substituir as florações da $\operatorname{arte}^{56}$.

Outro ponto analisado por Azevedo na obra de Schelling é o da noção de gênio que ela definiu como "o divino que habita o ser humano". O gênio era produtor de sua arte, utilizando, para isso, aquilo que mais próximo ele possui de Deus. Para a pesquisadora, a relação do homem com o gênio "é uma única e mesma relação àquela por meio do qual o mundo em si é produzido no ato originário de conhecimento, e aquela por meio da qual, no ato do gênio, é produzido o mundo da arte, como sendo o mesmo mundo em si (...)" 57 .

O que se desenvolveu em comum entre os românticos, apesar das diferenças existentes, é a ideia de uma poesia transcendental, que reflete sobre a própria poesia e incorpora a filosofia em sua atividade reflexiva. Era necessário ao homem moderno ter consciência de seus atos e, mais do que isso, na ação (ou seja, do fazer poético) o produtor faz parte de sua produção, ou seja, o produto passa a conter uma consciência de sua produção (torna-se "uma epopeia de um espelho de todo o mundo circundante" ${ }^{58}$ ).

A posição dos românticos, face à realidade que os envolvia, parece análoga àquela que Pasolini enfrentava na Itália do século XX, marcada por certo

\footnotetext{
${ }^{54}$ AZEVEDO, C.A., Filosofia da arte e os primeiros elementos para a formulação da filosofia na mitologia. In: Arte e filosofia, p. 21.

${ }^{55}$ Ibid. p. 21.

${ }^{56}$ Ibid., p. 21.

${ }^{57}$ Ibid., p. 21.

${ }^{58}$ DUARTE, P., op. cit., p. 49.
} 
incômodo e desejo de fuga. Tal sensação, assim como levava os românticos a buscarem uma reaproximação da natureza, também motivava a aproximação de Pasolini com a cultura campesina, dialetal. Enquanto no romantismo a natureza era compreendida como parte importante para o artista encontrar seu "sentimento interior", a cultura campesina também provocou em Pasolini uma experiência de autoconhecimento, dando-lhe uma sensação de "vida e de realismo", fato que muito o estimulava a compor versos em dialeto friulano. Nesse sentido, apesar de divergirem quanto ao modo, tanto os preceitos românticos quanto os relatos das experiências pasolinianas refletem a importância da natureza como espaço de idealização de uma realidade que era fundamental para a atividade poética.

Desse modo, pode-se concluir que, se para Schlegel a poética como fonte do conhecimento e do fazer é inesgotável, e, em Schelling, ela é absoluta, e mítica, portanto, o conhecimento absoluto é e está em Deus, Criador do mundo e da natureza. E dentro dessa interpretação mitológica/religiosa da realidade e da natureza, entra em cena o gênio criador, fundamental à filosofia da arte romântica.

Nessa relação entre filosofia, arte, gênio e mito, outro elemento fundamental às ideias que iam sendo construídas pelos românticos diz respeito à linguagem. Para Novalis e Schlegel, por exemplo, "pensar, falar e agir são conectados nessa visão de mundo, e a linguagem oriunda dessa constelação é mágica, absolutamente criadora- como a linguagem de Deus no início da Bíblia: ‘ Pensar é fala. Falar, atuar e fazer são uma operação modificada" ${ }^{59}$.

O que se pode perceber pelas definições dadas pelos pensadores românticos é que muitos elementos que antes já faziam parte da teoria viquiana estão presentes ao longo da construção filosófica do movimento: uma linguagem proveniente da fantasia e da imaginação, uma mitologia norteadora da realidade e a relação do homem com a natureza tal como Pasolini preconizava. Mesmo que não tenham sido leitores do pensador napolitano, as ideias circularam e, de todo modo, muitos desses elementos também se encontravam presentes em Rousseau, por exemplo, de quem os românticos teriam tirado inspiração para a construção de seu pensamento. A ideia de uma racionalidade poética e a valorização de uma

\footnotetext{
${ }^{59}$ SELIGMAN-SILVA, M., Friedrich Schlegel e Novalis: poesia e filosofia. In: Terceira Margem, p. 2.
} 
imaginação criativa estavam presentes, mesmo que não explicitamente, nesses pensadores.

Se as pesquisas não conseguem definir uma influência direta de Vico no pré-romantismo, a presença de elementos de sua filosofia é um consenso entre aqueles que se dedicaram ao tema (como Auerbach e Isaiah Berlin). Nesse mesmo sentido, para Pasolini, Herder seguia o mesmo caminho de Vico e Rousseau em seu trabalho sobre os cantos populares ${ }^{60}$. A influência comprovada do pensador napolitano aos românticos seria relevante às análises pasolinianas? Muito provavelmente não. $\mathrm{O}$ que se tenta defender aqui é antes a capacidade dos ensaios pasolinianos em vincular as suas referências em torno de uma ideia de poesia popular (dialetal) de maneira pessoal, preocupando-se menos em verificar seus argumentos do que identificar a noção de poesia nessas referências.

\subsection{A (des) construção de uma ideia de poesia popular: Vico e o romantismo por Benedetto Croce}

Como já foi apontado no início desse capítulo, a influência de Benedetto Croce nos ensaios sobre poesia pasolinianos é significativa. Entre todas as referências tomadas por Pasolini, Croce foi o que mais próximo esteve de sua época e, por isso, das discussões levantadas por ele sobre uma ideia de poesia popular. A leitura que Croce fez em La filosofia de Giambattista Vico vem a ser uma das mais importantes análises sobre a obra viquiana, e o ensaio Poesia popolare e poesia d'arte é considerado por Pasolini como fundamental aos estudos sobre o Romantismo italiano.

A leitura que Croce faz da Ciência Nova segue uma interpretação própria, que pode ser definida como estética. Por considerar a linguagem poética (entendendo-a como criação literária) como a primeira manifestação do espírito, e a forma estética como linguagem em si, Croce elegeu Vico como o primeiro descobridor da estética ${ }^{61}$ :

\footnotetext{
${ }^{60}$ PASOLINI, P. P., Un secolo di studi sulla poesia popolare. In: Passione e Ideologia, p. 141.

${ }^{61}$ CROCE, B., Estetica come scienza dell'espressione e lingüista generale, p. 1-2.
} 
Sob um aspecto filosófico, a Ciência Nova, por uma preponderância que tem as pesquisas das formas individualizantes e em especial da fantasia (a doutrina dos primeiros povos como poetas e de seu pensamento por caracteres poéticos é, disse Vico, a "chave mestra" da obra), se pode, sem paradoxo, definir uma filosofia do espírito com particular respeito à filosofia da fantasia, isto é, a Estética.

A estética é considerada verdadeiramente uma descoberta de Vico ${ }^{62}$.

Croce apresenta a obra de Vico em três partes essenciais, de modo a demonstrar as várias significações presentes na relação entre filosofia e filologia: uma "filosofia do espírito", uma "história (ou grupos de histórias) " e uma "ciência social"63. Essa foi a organização que ele identificou nos livros da Ciência Nova que, de acordo com ele, permitiram a Vico apresentar os axiomas (ou "Dignidades") de sua Ciência, buscando compreender o movimento dos homens, cuja organização em grupos, nações e etnias foi constituinte da história. Como dito anteriormente, tal caminho percorrido pelos homens contou com elementos essenciais, como a natureza, a mitologia (religião) e o desenvolvimento da linguagem, que são construções humanas e, ao mesmo tempo, ajudaram os homens em sua formação. Croce avança na análise e identifica que a poesia em Vico não se apresenta como um capricho e um prazer, mas sim como uma necessidade da natureza humana, pois "sem essa, não surgiria o pensamento: é a primeira operação da mente humana" ${ }^{24}$.

Ao pensar na problematização da poesia em Vico como linguagem, Benedetto Croce afirma não ter sido essa questão debatida ou pensada até o século XVIII. Comumente a linguagem, segundo Croce, “(...) costumava confundir-se com a lógica ou rebaixada a simples signo extrínseco e convencional ou, por desespero, declarada como de origem divina" ${ }^{65}$. Vico, concluiu Croce, opôs-se a essa definição, mais uma das razões pelas quais muitos de seus leitores o apontam como um homem fora de seu tempo. A ideia de uma origem divina da poesia seria para ele "refúgio dos preguiçosos". Além disso,

\footnotetext{
62 "Sotto l'aspetto filosofico, la Scienza nuova, per questa preponderanza che vi ha l'indagine delle forme individualizzanti e in ispecie della fantasia (la dottrina dei primi popoli come poeti e del loro pensare per caratteri poetici è, dice il Vico, «la chiave maestra »dell'opera), si potrebbe non troppo paradossalmente definire una filosofia dello spirito con particolare riguardo alla filosofia della fantasia, cioè all'Estetica. L' Estetica è da considerare veramente una scoperta del Vico" (CROCE, B., La filosofia de Giambattista Vico, p. 47).

${ }^{63}$ Ibid., p. 37.

64 “(...)senza di essa, non sorge il pensiero: è la prima operazione della mente umana” (Ibid., p. 49).

${ }^{65}$ l linguaggio si soleva, a volta a volta, o confonderlo con la logicità o abbassarlo a semplice segno estrinseco e convenzionale o, per disperazione, dichiararlo di origine divina" (Ibid., p. 50).
} 
(...) a linguagem não é lógica nem arbitrária, e, como a poesia, não é produto nem da sabedoria oculta nem de beneplácito ou convenção. A linguagem surge naturalmente: na primeira forma, os homens se explicavam "com atos mudos", ou por gestos, e "com o corpo tendo uma natural relação com as ideias que queriam dizer", já por objetos simbólicos ${ }^{66}$.

Os apontamentos de Vico são colocados entre um conjunto de ideias que existiam desde a Antiguidade, e que foram persistindo ao longo dos anos e chegaram à Idade Moderna. Assim, para Croce,

Vico expõe uma ideia de poesia, que era naquele tempo e deve ter sido durante um bom tempo, uma ardente e revolucionária novidade. Persistia uma velha ideia pedagógica que veio da Antiguidade tardia, atravessou a Idade Média, se enraizou e radicou no Renascimento, da poesia como engenhoso revestimento popular de sublime conceito filosófico e teológico ${ }^{67}$.

Vico, de acordo com a interpretação dada por Croce, opôs-se àquela ideia de que a poesia era fruto da engenhosidade (ou seja, do pensamento) popular, meio de expressão de uma cultura ligada à comicidade e aos ritos de grupos plebeus, por exemplo. Vico, portanto, inovou ao inverter e colocar a poesia como produtora de uma visão de mundo, da mitologia ou como construtora do próprio homem, a partir de uma concepção de poesia vinculada à metafísica, comum a todos os humanos. A imaginação adquiria, assim, o status de uma categoria de conhecimento.

Quanto às reflexões de Croce sobre o Romantismo italiano, Pasolini atribui ao ensaio Poesia popolare a poesia d'arte (1929) o maior estudo sobre o século XIX folclórico, ou seja, referente aos estudos de pesquisa de poesia popular do Oitocento italiano. Do mesmo modo como Pasolini faz referência a Dante e a Vico, ele cerca-se da importância da obra croceana para fundamentar as discussões propostas em seus ensaios sobre poesia. Apesar de fazer maior

\footnotetext{
66 “(...) un rifugio da pigri, e che il linguaggio non è né logicità né arbitrio, e, al pari della poesia, non è prodotto né di sapienza riposta né di placito o convenzione. Il linguaggio sorge naturalmente: nella prima forma di esso, gli uomini si spiegarono «con atti muti », ossia per cenni, e " con corpi aventi naturali rapporti alle idee che volevano significare », ossia per oggetti simbolici." (Ibid., p. 50).

67 "Vico espose una idea della poesia, che era a quei tempi, e doveva rimanere per um pezzo ancora, un'ardita e rivoluzionaria novità. Persisteva allora la vecchia Idea praticistica o pedagogica, che dalla tarda antichità, attraverso Il Medioevo, si era trapiantá e radicata nel Rinascimento, della poesia come ingegnoso rivestimento popolare di sublimi concetti filosofici e teologici" (Ibid., p. 48).
} 
referência a elas nos ensaios dedicados especificamente à história dos estudos sobre poesia popular na Itália, é possível perceber, por exemplo, como as mesmas se fazem presentes em todos os ensaios reunidos em Passione e Ideologia.

Poesia popolare e poesia d'arte: considerazioni teorico-storiche foi dividida em quatro partes, de modo a comportar o tipo de análise que Croce gostaria de realizar a respeito do dualismo existente entre o que era popular e o que era erudito. A primeira parte é apresentada ao leitor sob o título Che cosa possa chiamarsi propriamente "poesia popolare", a segunda foi intitulada de La poesia popolare in quanto símbolo estético, político e morale. As duas últimas partes evoluem do caráter de apresentação dos temas para realizar o debate ao qual Croce se propôs, e foram intituladas, respectivamente, como La poesia popolatre nella critica letteraria italiana e Il tono popolare nella letteratura italiana $^{68}$.

$\mathrm{Na}$ apresentação de sua obra, Croce definiu clara e explicitamente os princípios norteadores do texto:

\begin{abstract}
A linha de meu pensamento é constantemente aquela de acolher os motivos românticos do intelectualismo e da passionalidade; mas, apenas para manter ou para restituir ao clássico a sua seiva e a sua força vital, prevenindo de se perverter no classicismo e academismo, e não para mortificar a poesia condenando-a a uma espécie de pobreza mental ou infantilidade ${ }^{69}$.
\end{abstract}

Mesmo questionando os critérios românticos, Croce fez uso deles para analisar a poesia dita popular na Itália. A análise romântica sobre o folclore italiano, bem como seu trabalho de coleta do material era, sem dúvida, para ele o mais completo trabalho de catalogação existente até aquele momento, sendo que os preceitos românticos continuaram exercendo grande influência nas pesquisas sobre cultura popular no século XX.

\footnotetext{
${ }^{68}$ CROCE, B., Poesia popolare e poesia d'arte. In: La crítica. Rivista di Letteratura, Storia e Filosofia diretta da B. Croce.

69 "La linea del mio pensiero e stato costantemente quella di accogliere i motivi romantici dell'antintellettualismo e della passiona- lita; ma soltanto per serbare o per restituire al classico la sua linfa e la sua forza vitale, impedendogli di pervertirsi nel classicistico ed ac- cademico, e non certo per mortificare la poesia condannandola a una sorta di povertai mentale o addirittura d'infantilism" (CROCE, B. Poesia popolare e poesia d'arte. In: VITTORINI, D. Benedetto Croce e la critica: Considerazioni sul recente suo lavoro: poesia popolare e poesia d'arte, p. 140).

A introdução da obra de Poesia popolare e poesia d'arte, infelizmente não se encontra disponível na versão da obra que foi utilizada neste trabalho e que foi disponibilizada no site da Fondazione Benedetto Croce. (Ver: http://www.fondazionebenedettocroce.it/.).
} 
No entanto, logo no início de seu texto, Croce pontuou que definir poesia popular não é tarefa fácil, e que isso só se tornava possível a partir do que ela não era, ou seja, a partir de uma definição do que seria poesia erudita (d'arte), mas que essa mesma distinção é insustentável. Segundo ele, a definição de poesia popular, por exemplo, como "anônima, improvisada", que "nasce do povo, isto é, da classe inferior (...) de origem e difusão coletiva, se transmite pela tradição oral" seria um erro, pois, “ não só a classe humilde compõe poesia popular”, tampouco a classe superior produziria poesia culta ${ }^{70}$. Além disso, a noção de coletividade atribuída à poesia popular pelos românticos é questionada por Croce, visto que nenhuma poesia surge na coletividade, sendo necessária a figura de um poeta para compô-la ${ }^{71}$. Ou seja, no máximo a coletividade se faz presente no momento de sua transmissão oralizada. Para Croce, portanto, relativizar essas distinções era fundamental, questionando as principais explicações acerca da oposição "popular" e "erudito".

Ele adotou um princípio analítico que, assim como o dos românticos, forjou uma distinção entre popular e erudito, mas Croce entende que o verdadeiro critério para avaliar a qualidade de uma poesia deve passar longe de definições externas, tal como a análise filológica; a poesia deve ser analisada pelos aspectos internos ou psicológicos inerentes à sua composição. Ele acredita que é fundamental pensar em distinções "de tendência ou de prevalência e não de essência"72, para, em seguida estabelecer seus critérios de diferenciação, moral, intelectual, e estética, que se complementam, e que fariam parte dos elementos psicológicos inerentes à poesia. A poesia popular seria na esfera moral o produto da ação natural, que não conheceria maldade, enquanto a poesia erudita "conhece a paixão e suas armadilhas, à medida que teve que lutar contra elas"73; intelectualmente as poesias seriam pautadas no que ele definiu como "bom senso", demonstrado na poesia popular através dos provérbios, da sabedoria do mundo. Esteticamente, as esferas poéticas seriam análogas ao que eram no senso moral e intelectual. A popular era dotada de sabedoria e sentimentos naturais, e a

70 “(...) anonima, improvvisata, nasce dal popolo, ciò̀ dalla classe inferiore, come a dire contadini e pastori, há origine e diffusione colletiva, si trasmette per tradizione orale (...)”. [Tradução Livre]. Ver: CROCE, B., .Poesia popolare e poesia d'arte. In: La crítica. Rivista di Letteratura, Storia e Filosofia diretta da B. Croce, p. 321.

71 "non solo le classi umili compogono poesia popolare, nè solo quelle colte poesia d'arte (...)" (Ibid., p. 321).

72 “(...) di tendenza o di prevalenza e non già di essenza(...)” (Ibid., p. 323).

${ }^{73}$ Ibid., p.324. 
erudita aquela que resulta dos males (da sociedade) e de uma percepção mais austera do mundo (sem o elemento mágico).

Para o autor, o ritmo e a motivação da poesia popular se adequam tanto na poesia popular quanto na erudita, de acordo com os preceitos definidos por ele. A fim de exemplificar seu argumento, Croce utiliza-se da obra do escritor Niccolò Tommaseo:

A coloração do sentimento, o ritmo, a mesma massa de linguagem, dão a esta palavra uma profundidade que faz as outras parecerem como se fossem desenvolvidas na superfície. Mas não são superficiais nem mesmo aquelas: mesmo naquelas treme de emoção; são elementarrmente humanas. Tal é a característica de toda a poesia popular que vem a nossa memória ${ }^{74}$.

Conferir à poesia popular um caráter de profundidade e emoção não qualifica a poesia erudita como superficial, adverte. Croce coloca-se, mais uma vez, contra uma visão romântica que classifica um tipo de poesia como oposta à outra. Ele não renega que entre elas haja um combate, o que, no entanto, não justifica contrapô-las quanto à composição, métrica, motivos ou sentimentos. Em outra passagem, ele continua se colocando contra a acepção mais comum dos estudos românticos que insistem em definir o culto como contrário ao popular. Ele cita o exemplo de uma mãe campesina napolitana, que invoca através da magia o santo protetor do sono de seu filho. Para Croce, as operações de magia contêm um misto de elementos simples, mas também cultos em seu modo poético de expressão.

A poesia popular não é mais confundida com outro tipo de poesia (...) Não é essa a poesia pela qual se entende uma poesia escassa de elementos intelectuais e rica em sensibilidade e fantasia; não é a poesia e a arte pueril ou infantil, que corresponde à mente infantil e não propriamente ao ânimo simples e elementar; não é a poesia dialetal, porque embora ela se ligue facilmente ao dialeto, este pode abrigar e muitas vezes abriga, também, a psicologia do homem culto e a poesia de $\operatorname{arte}^{75}$.

\footnotetext{
74 "La colorazione del sentimento, Il ritmo, lo stesso impasto del linguaggio danno a queste parole uma profundità che fa apparire le altre come se si svolgessero in superfície. Ma non sono superficiali neppur quelle: anche in quelle trema la commozione; sono elementarmente umane. Tale è Il carattere di tutte Le poesie popolari che affiorano alla nostra memória” (Ibid., p. 325).

75 "la poesia popolare non è più da confondere com altri tipi di poesia (...) Non è essa la poesia "primitiva", per la quale s'intende uma poesia scarsa d'elementi intelletuali e ricca di quelli sensibili e fantastici; non è la poesia e l'arte "puerile" o "fanciullesca", che corrisponde all'anima e alla mente fanciullesca e non propriamente all'anima e alla mente semplice Ed elementare; non è la poesia "dialettale”, perchè, sebbene essa si leghi agelvolmente al dialetto,
} 
Ao final de seu ensaio, não há uma definição clara dada por Croce do que seria poesia popular, tampouco uma definição sobre a "poesia de arte". Isso, no entanto, não demonstrou ser sua intenção ao longo do texto. O que há, certamente, é o interesse em questionar a estética romântica como polarizadora de uma distinção entre os dois tipos de poesia. A partir dessa conclusão, ou seja, de determinar como as definições herdadas do século XIX romântico seriam superficiais e incorretas, Croce parte a outra etapa de sua análise ao tentar complexificar e, assim, analisar a poesia popular enquanto conceito estético, moral e político. Pode-se dizer que a segunda parte é o momento-chave de sua obra, quando ele, de fato, vai se colocar em relação a todos os elementos postos em pauta no capítulo precedente e, não por acaso, este é o capítulo ao qual Pasolini mais faz referências em seus ensaios.

A problematização de Croce quanto ao conceito estético de poesia começa pela diferenciação entre a ideia de poesia racionalista, de influência classicista, e aquela que surge na Alemanha na segunda metade do século XVIII, que deu início aos estudos de Herder, ao movimento Sturn und Drang e que culminaria no Romantismo, conforme visto e discutido no início do capítulo. A Alemanha despontou como precursora do questionamento da noção de poesia clássica. Segundo Croce, a poesia original não era obra do intelecto, "mas pura criação da fantasia sobre um assunto que é oferecido pelo sentimento e pela paixão ${ }^{76 "}$.

A organização e as influências intelectuais reivindicadas pelos românticos teriam, no entanto, problemas. Segundo Croce,

(...) a poesia não possuiria nenhuma dependência necessária da divisão em períodos ou classe social, e que o tom popular e o tom de arte, o elementar e o complicado, o espontâneo e o reflexo, ou como alguns gostam de denominar, esta diversidade psicológica é de todos os tempos ${ }^{77}$.

questo può accogliere, e a volte accoglie, anche la psicologia dell'uomo colto e della poesia d'arte (Ibid., p. 328).

76 “(...) la poesia schietta, che è non opera dell intelleto, non calcolo per certi fini, ma pura creazione della fantasia sulla materia offertale dal sentimento e dalla passione" (Ibid., p. 331).

77 “.... la poesia non há alcuna necessaria dipendenza dalle divisioni delle età e delle classi sociali, e che il tono popolare e il tono d'arte, l'ementare e il complicato, lo spontaneo e il rifesso, o come altrimente piaccia denominare questa diversità psicologica, sono di tutti i tempi" (Ibid., p.332). 
As críticas ao Romantismo em Croce possuem raízes profundas. Elas estão ligadas ao seu sistema de pensamento, que tem como principal fundamento sua ideia de estética como parte de um grande Espírito universal e identificada por ele como fundamento de toda uma visão de mundo e de comportamento humano ${ }^{78}$. De acordo com Angelo Ricci, o primeiro momento de cognição desse Espírito é o da sensibilidade,

forma elementar, necessária e eterna do Espírito, irredutível a qualquer outra forma por ser original e não eliminável porque, com a sua eliminação, se destruiriam as outras manifestações do Espírito. Para Croce é deste momento essencial que surge a arte. (...) A arte não é, pois, um privilégio de alguns eleitos ou um apanágio exclusivo do gênio: ela é função ou atributo natural do homem. Consequentemente ela é universal ${ }^{79}$.

A arte é expressão da intuição, forma teorética dos sentimentos e, de acordo com a teoria croceana, a intuição seria uma atividade inerente a todos os homens. Não existiria um gênio, criatura privilegiada por um dom - todos seriam capazes de produzir arte. A sua noção de arte, por sua vez, não estabelece distinções naturais. Poesia, música, pintura são variáveis enquanto forma, e não em sua função de expressão dos sentimentos. Croce inspirou-se em Vico para definir essa relação entre arte e poesia, baseando-se na noção de que a arte (poesia), como forma de expressão, é proveniente da fantasia ${ }^{80}$. A arte em Croce também não perderia esse caráter instintivo, sendo impossível para ele aceitar a definição de poesia, por exemplo, como produto de uma "atividade vigilante e austera", enquanto a poesia popular como algo natural, produto da ingenuidade. Não haveria uma distinção desse gênero, visto que a poesia, como forma de arte, estaria sempre relacionada à intuição, sendo ela culta ou popular.

Com isso, Croce, mais uma vez, coloca em xeque a oposição entre erudito e popular, negando a principal tese usada pelos românticos. Havia, segundo ele, uma necessidade dos homens em recuperar o passado diante da decadência e da mortalidade da arte. Esse passado residia, justamente, no mundo da poesia ${ }^{81}$. Esses artífices, para estabelecer a crítica à estética do mundo moderno e industrial,

\footnotetext{
${ }^{78}$ RICCI, Angelo. Benedetto Croce.

79 Ibid., p 21.

${ }^{80}$ Ver introdução: VICO, G. Ciência Nova.

${ }^{81}$ Ver: CROCE, B., Poesia popolare e poesia d'arte. In: La crítica. Rivista di Letteratura, Storia e Filosofia diretta da B. Croce, p. 332.
} 
iam procurar no folclore, no popular e no primitivismo os elementos para a construção de uma nova arte. Croce, dessa forma, busca explicar toda a tradição reivindicada pelos românticos como uma tentativa de forjar uma autenticidade essencial, relacionada ao tipo de análise que era feita por eles sobre o folclore.

\title{
2.6. Pasolini leitor de Croce: uma crítica à Poesia popolare e poesia d'arte
}

Existe uma fenda entre o tipo de análise desenvolvida por Croce e aquela que seu leitor Pasolini realiza alguns anos depois sobre a poesia popular romântica. Enquanto Croce elabora uma análise dos romantismos alemão e italiano de maneira mais genérica, como também os reflexos desses estudos no século XX, é possível perceber em Pasolini uma tentativa de explicar - através da análise estética e sociológica herdada do Romantismo do século XIX - os caminhos pelos quais a sociedade italiana chegou ao que ele definiu como um “apocalipse cultural”. Sobre a relação da cultura popular com a cultura erudita, ele afirmou:

\begin{abstract}
A operação de toda a classe dirigente sucedeu-se no tempo e consistia em transferir, por coação ou não, a própria ideologia às classes dominadas: quase sempre se valendo do espírito conservador desta última: a nova ideologia vinha aparentemente a coincidir com a forma conservada da ideologia precedente e fundida na tradição, fruto monstruoso e rigoroso de sucessivos resíduos, sedimentos e sobrevivências.

A poesia popular é um produto dessa relação ${ }^{82}$.
\end{abstract}

Mesmo com as diferenças de sua interpretação e aquela de Croce, Pasolini orienta-se a partir da leitura das obras croceanas para construir seu argumento em torno de uma autenticidade da poesia popular italiana, aqui identificada como a poesia dialetal. Com ou sem críticas, era impensável estudar o recolhimento dos cantos populares durante o século XIX sem passar por Croce. Contudo, há um cuidado de Pasolini em fazer uso das teses crocenas de modo que elas servissem como fundamento às suas próprias ideias.

\footnotetext{
82“"La operazione di tutte Le classi dirigenti succedutesi nel tempo è consistita nel trasferire, per coazione o no, la própria ideologia alle classi dominate: quase sempre valendosi dello spirito conservativo di queste ultime: sì che la nuova ideologia veniva apparentemente a coincidere com le forme conservate dell' ideologia precedente e fuse nella tradizione, frutto mostruoso e rigoroso di successivi residuati, sedimentazioni e sopravvivenze" (PASOLINI, P. P., Il problema. In: Passione e Ideologia, p.164).
} 
Tomando como ponto de partida a obra Poesia popolare e poesia d'arte, Pasolini entendeu a análise croceana como fundamental aos estudos sobre o folclore italiano. A partir da obra de Croce, ele se propôs pensar a poesia popular italiana em seu desenvolvimento histórico, cultural e como ato poético. Ele aponta que o Romantismo italiano entrou em voga na Europa quando na Alemanha e na França o estudo dos cantos populares já era questionado. Assim, mesmo tardiamente, os estudos sobre poesia popular coletiva também se desenvolveram na Itália, com o recolhimento dos cantos populares toscanos por Tommaseo, por exemplo, que transformou a dita "miséria psicológica" do povo em poeticidade ${ }^{83}$. O trabalho desse linguista valorizava aspectos do que Pasolini definiu como uma "religiosidade natural do povo", típica de uma "interpretação romântico-católica". Tommaseo marcaria, portanto, o que Pasolini definiu como a primeira fase do romantismo tardio italiano, caracterizada, justamente, por essa forma de recolhimento dos cantos populares.

A segunda fase, chamada por Pasolini de científica - de acordo com a divisão estabelecida anteriormente por Croce - foi marcada pela "teoria da monogênese do canto popular italiano", que ele definiu como a atribuição dada a Sicília de berço do canto popular, o qual teria se difundido na Itália durante o século XIV e, a partir da Toscana, difundiu-se a outras partes ${ }^{84}$. O recolhimento dos cantos populares não era realizado na Itália até o século XIX. Mesmo assim, eles foram considerados pelos folcloristas como possuindo uma origem comum, tanto em relação à língua quanto aos temas. Assim, Pasolini cita D’Anconna, importante linguista, estudioso dos cantos italianos,

(...) A maior parte dos cantos populares é, evidentemente, nascida em Isola (Sicília), e vinha (...) modificando-se até que, chegando até o meio da Itália, retirou a veste dialetal, e por eficácia da nova forma toscana, coisa similar à linguagem comum, irradiou ao seu entorno ${ }^{85}$.

D’Anconna foi um dos principais nomes da segunda fase do romantismo italiano, e sua obra, Poesia popolare italiana, marca o início do chamado período científico dos estudos sobre poesia dialetal italiana. A análise filológica de

\footnotetext{
${ }^{83}$ Id., Un secolo di studi sulla poesia popolare. In: Passione e Ideologia, p 144

${ }^{84}$ Ibid., p. 146.

85 "La maggior parte dei canti popolari è evidentemente nata nell'Isola [di Sicilia], e poi venuta su su, più o meno modificandosi per via, finchè giunta nel mezzo d'Itália, há spogliato la veste dialettale, e per l'efficacia della nuova forma toscana, cosi símile al linguaggio comune, há raggiato all 'intorno"(Ibid., p. 147).
} 
D’Anconna segue um critério geográfico, e é através deste que o linguísta estabeleceu uma divisão do canto em dois tipos: o canto lírico (no Sul), e outro épico-lírico (Norte), apesar de uma mesma origem lingüística e base substancialmente iguais. Esse autor e sua obra serão fundamentais aos estudos posteriores sobre os cantos populares. Após a divisão filológica de D’Anconna, Pasolini cita Nigra e Pitrè como importantes pensadores dos estudos demopsicológicos italianos ${ }^{86}$. O resultado desses estudos teria conferido à cultura popular um caráter literário, proveniente da influência do romantismo tardio, e um caráter político, proveniente do Risorgimento e do movimento proto-socialista ${ }^{87}$.

A terceira fase dos estudos sobre canto popular, definida como fase estética, surgiu, segundo Pasolini, somente no início do século XX, com a obra Poesia Popolare e poesia d'arte (1929), de Benedetto Croce. Essa obra é apresentada no ensaio pasoliniano em virtude de sua importância ao entendimento do século XIX folcloristico ${ }^{88}$, apesar de a interpretação croceana sobre poesia popular ir de encontro ao movimento intelectual do século anterior, influenciado pela visão "mítica" do romantismo tardio. Pasolini vale-se, então, dos escritos de Croce, que atribuiu o problema da interpretação romântica antipositivista do século XIX ao fato de ela considerar a poesia popular em seu aspecto simbólico, desconsiderando uma análise histórica e filosófica. A partir das considerações de Croce acerca desse movimento, Pasolini conclui que o romantismo faz da poesia "o símbolo de um conceito estético, de um conceito político e de um conceito moral" 89 .

\footnotetext{
${ }^{86}$ Giuseppe Pitrè (1841-1916) foi um folclorista italiano, responsável por sistematizar o estudo sobre o folclore. Entre suas principais obras, estão, Curisosità popolari tradizionali e Bibliografia delle tradizioni popolari d'Italia. Ver: http://www.treccani.it/enciclopedia/giuseppe-pitre/.

${ }^{87}$ Período da história italiana considerado aquele em que os italianos deram início à "Nação" e entraram no "mundo moderno". Através do Risorgimento, os italianos mergulharam em diferentes transformações, como o fim do Antigo Regime, o desenvolvimento do sistema parlamentar, a quebra da tradicional sociedade rural, e o nascimento de uma sociedade moderna. No núcleo desta modernidade se encontra o modo de vida predominantemente urbano, engendrando a transição de uma economia feudal para uma capitalista e a mudança de uma identidade local ou regional para uma ideia de cultura nacional (ver RIALL, L., The Italian Risorgimento: state, society, and national unification, p. 1). Lembrando que, apesar das definições, o Risorgimento não conseguiu estabelecer uma unificação linguística na Itália, marcada por anos de uma independência cultural e política na região. Posteriormente, ao longo do regime fascista, houve uma nova tentativa de unificação cultural, na tentativa de homogeneizar a língua e estabelecer o "italiano médio", conforme aponta Pasolini em diversos textos. Ainda segundo ele, a modernização econômica na Itália também foi limitada nos anos do Risorgimento, tendo ocorrido uma intensificação da industrialização e, assim, a entrada italiana na "modernidade" somente após a queda de Mussolini,a partir dos anos 50.

${ }^{88}$ PASOLINI, P.P., Un secolo di studi sulla poesia popolare. In: Passione e Ideologia, p. 152.

${ }^{89}$ Ibid., p. 153.
} 
O conceito estético de poesia popular a que se refere o Romantismo, como foi informado anteriormente, teria referência em Vico. Esse conceito era o da poesia como ato poético:

A poesia, contudo, não opera do intelecto... mas como pura criação da fantasia...a fonte de tal poesia lembrava a imagem da natureza contra a cultura...e a sua ideia...se exemplificava na poesia primitiva e barbára, a sua volta universalizada e identificada com o conceito de poesia genuina. E como representante do bárbaro e do genuíno, apareceu o povo...o conceito de "poesia por excelência" se fundiu com aquele de "poesia popular"

O fato de Croce e, nessa mesma linha, Pasolini verem o movimento romântico como uma apropriação dos elementos da teoria viquiana permite pensar a noção de "povo" - do modo como os românticos a entendiam - de maneira análoga aos primeiros homens. Da mesma forma que a linguagem poética como “primeira linguagem" entre os homens era atribuída aos povos ditos primitivos e exaltada por Vico como linguagem original, para Herder e os românticos a poesia popular era entendida como única poesia, tendo como critério legitimador uma ideia de "originalidade" e o fato de ser considerada como produto da "criação coletiva" do povo, formador de uma "nação".

O segundo conceito identificado por Pasolini na obra de Croce seria o político, caracterizado pela oposição da paixão romântica ao racionalismo iluminista ${ }^{91}$ e que surge em função do primeiro conceito, o estético. A oposição dos românticos aos iluministas teria ocorrido de algumas formas. Primeiramente, a teoria viquiana - de acordo com a interpretação que Pasolini faz, por sua vez, da leitura croceana - aponta a linguagem (poética) dos primeiros homens como a linguagem por excelência e ela seria proveniente da fantasia e não do intelecto. Pasolini também aponta a crítica romântica quanto aos critérios racionalistas adotados por alguns países na organização territorial de povos e nações. As concepççoes de nacionalismo e povo aos românticos eram categorias naturais, simbolizadas pela arte e pela poesia

No entanto, a ideia de nação que se construiu a partir da interpretação iluminista se fortaleceu e o povo tornou-se, segundo a citação de Pasolini sobre

90 "La poesia schietta, non opera dell'intelletto...ma pura creazione della fantasia... La fonte di tale poesia richiamava l'immagine della natura contro la cultura...e la sua idea... si esemplificava nella poesia primitiva e barbarica, a sua volta universalizzata e identificata col concetto della poesia genuina. E poichè supérstite rappresentante del barbárico e del genuíno appariva Il popolo...il concetto di "poesia per eccellenza" si fuse con quello di "poesia popolare” (Ibid., $153)$.

${ }^{91}$ Ibid., p. 153 
Croce, "entidade ou categoria da humanidade (...) a poesia e a arte foram concebidas nacional e etnicamente" 92 . Ou seja, a categorização iluminista impregnou o período do romantismo, tornando o povo e a nação categorias inerentes à organização das sociedades. Desse modo, o conceito ético ou moral que seria o terceiro conceito romântico - surge a partir do fortalecimento dessas duas categorias, nação e povo. Sobre isso, Pasolini afirmou que essas categorias eram:

Ideais éticos que, por sua vez, se identificaram no povo como única entidade não egoísta - oposta ao egoísmo individual - e quase a encarnação do divino. Sob esta "base ética", apesar de diversa e contrastante, se encontram, por exemplo, o nacionalista reacionário Achim Von Arnim e o nacionalista revolucionário Giuseppe Mazzini. Para ambos vale o binômio " Povo e Deus", sendo o povo o verdadeiro mediador da palavra divina: e, como consequência, no âmbito literário, a verdadeira poesia sendo a poesia popular ${ }^{93}$.

O conceito de povo tal como os românticos o desenvolveram, tornou-se uma categoria acima do tempo e do espaço, bem como de distinções políticas ou culturais. Desse modo, o romantismo colocou idealmente a origem da poesia popular em um indeterminado período protohistórico, divino, sendo ela produto de uma coletividade que daria origem à nação e ao povo, o que influenciou e permaneceu presente na interpretação da cultura popular do século seguinte. Opondo-se a essa visão romântica que permanece ao longo dos estudos do século XX, surgiu, então, a obra de Croce Poesia popolare e poesia d'arte. A relevância desta na interpretação pasoliniana reside, justamente, em ter abalado os alicerces da herança romântica durante o século XX. Croce teria reduzido o dualismo entre poesia popular e erudita a um fenômeno meramente psicológico. Segundo Pasolini, Croce,

(...) se esforça para demonstrar como cada uma daquelas atribuições referentes à poesia popular são referentes também à poesia d'arte e, vice-versa, como cada

\footnotetext{
${ }^{92}$ Entità o categorie della realtà che soverchiano le stesse categorie della umanità (...) La poesia e l'arte fu concepita nazionale e etnica" (CROCE, B. apud. PASOLINI, P., Un secolo di studi sulla poesia popolare. In: Passione e Ideologia, p 154).

93 "Ideali etici che ancora uma volta si identificarono nel popolo come sola entità antiegoistica opposta agli egoismi individuali - e quase incarnazioni del divino. Su questa "base ética" sia pur diversa e anzi contrastante, si incontrano, ad esempio, il nazionalista reazionário Achim Von Arnim e il nazionalista rivoluzionario Giuseppe Mazzini. Per ambedue vale il binômio "Popolo e Dio", il vero mediatore della parola divina essendo il popolo: e di conseguenza, in sede letteraria, la vera poesia essendo la poesia popolare" (Ibid., p. 154).
} 
uma daquelas mesmas atribuições referentes à poesia d'arte são também referentes à poesia popular ${ }^{94}$.

A tese de Pasolini se constrói em conflito com a croceana, que é, justamente, a sua principal referência sobre romantismo. A obra de Croce, no entanto, apesar de se contrapor, apresenta bem os principais pontos concernentes a uma ideia de poesia popular, da qual todos os estudiosos posteriores valem-se. O que se pode entender, a partir da apresentação dos pontos de vista e argumentos de ambos os pensadores, é que, mais que criticar, Pasolini as utiliza até o ponto em que o seu argumento não se prejudicasse em função dessas ideias opostas. A partir de uma herança croceana, portanto, os estudos sobre a poesia popular tornaram-se mais abrangentes, entrando no que se convencionou chamar de fase científica, em que o estudo do folclore contou com um crescimento do número de materiais sobre o tema.

Nesse sentido, a herança do romantismo, bem como a croceana, definiram os contornos dos estudos sobre cultura e poesia popular no século XX italiano. Pasolini questiona-se sobre a origem do conceito de poesia popular: seria ele "um fenômeno da cultura popular ou da cultura burguesa?". O que se pode entender na interpretação pasoliniana, é que aquilo que está em questionamento não é uma noção sobre o popular ou o erudito, mas sim uma ideia de cultura tomada pela noção de uma divisão de classes, tipicamente marxista. O povo, segundo Pasolini, assumiu nas sociedades contemporâneas " plena consciência de seu ser, mas em uma relação de simples contato, válido como ponte em qualquer tempo de atraso muito grave que o separa na época histórica"95, e a poesia popular teria surgido então do contato,

(...) da parte baixa, uma mentalidade de tipo arcaico, primordial, capas de produzir poesia mesmo nas comunidades humanas mais atrasadas - tribos africanas, australianas, etc.- poesia que se pode definir folclórica, invocada em

\footnotetext{
94 “(...) si adopera a dimistrare come ognuna di quelle attribuzioni riferite alla poesia popolare è riferibile anche alla poesia d'arte, e come viceversa, priva dell'alfa privativo, ognuna di quelle stesse attribuzioni riferita alla poesia d'arte è riferibile anche la poesia popolare" (Ibid., 155).

95 “(...) ha preso coscienza del suo essere, ma um rapporto di semplice contatto, valido a colmare in qualche modo Il ritardo talvolta assai grave che lo separa nell'epoca storica" (Ibid., 164).
} 
apoio à teoria romântica. Da parte alta, uma mentalidade que se aproxima, por mimese, por influência, da vida moderna, histórica ${ }^{96}$.

Pasolini reproduz uma interpretação comum entre os críticos sobre aquilo que é considerado a distinção entre o popular e o erudito, como Vicenzo De Bartholomeis, onde os adjetivos "atrasado" e "baixo" são tomados como antítese a uma cultura superior, vanguardista. No entanto, adverte, a poesia popular não perderia, nesse contato, seu "tom original", visto que o estilo e a métrica culta seriam apropriadas pela poesia popular segundo os hábitos mentais típicos de uma cultura que ele convencionou chamar de pré-humanística ou prégiullaresca ${ }^{97}$.

Ao concluir seu ensaio Il problema, Pasolini aproxima-se de uma concepção de tipo croceano, definindo que a cultura popular e a erudita teriam uma origem cultural comum- no caso sua origem primitiva- como reflexo de uma evolução histórica, na qual o povo não sabia mais como produzir uma poesia de tipo folclórica ${ }^{98}$. Tal poesia era, por sua vez, muito mais próxima da poesia primitiva de tipo viquiano do que da poesia literária, cuja definição, para Pasolini, era similar àquela da poesia culta ou erudita. Ou seja, em Croce, a tensão entre os dois tipos de poesia é definida como de tipo meramente psicológico. Em Pasolini, tal distinção entre as poesias seria resultado de uma troca que se tornou inerente à disputa entre as classes, e o que produziria a poesia popular seria o sintoma de uma tomada de consciência do povo acerca de sua condição social. Desse modo, o critério adotado por Pasolini leva em consideração as distinções de cunho social, enquanto a de Croce prioriza o caráter mais íntimo, que envolve o poeta e o ato de sua composição. Para Croce, a poesia popular não pertence necessariamente às camadas mais baixas, tampouco a poesia erudita é resultado da composição de membros de uma elite intelectual dominante. Essa é a principal oposição entre eles.

\footnotetext{
96 “(...) dalla parte bassa, uma mentalità di tipo arcaico, primordiale, atto a produrre poesia anche nelle comunità umane più arretrate- le tribù africane, australiane ecc.- poesia che si può definire 'folclorica', invocata a sostegno della teoria romântica. Dalla parte alta, una mentalità che si approssima, per mimesi, per influenza alla vitta moderna, storica" (Ibid., 165).

${ }^{97}$ Tipo de poesia medieval que se caracteriza pela comicidade; poesia do ridículo.

${ }^{98}$ PASOLINI, P. P., Ibid., p. 170.
} 
A tese croceana acerca dessa relação/tensão entre o popular e o erudito abriu caminho, segundo Pasolini, para o desenvolvimento de teorias na Itália, como àquela desenvolvida por Antônio Gramsci, que vem a ser outro autor fundamental à formação pasoliniana. No entanto, a interpretação que Gramsci conferiu à distinção entre o popular e o erudito dedicou-se ao que Pasolini definiu como poesia "popularizante", ou seja, feita para e não pelo povo, ou seja, $\operatorname{artificial}^{99}$. Era essa a poesia que se desenvolveria ao longo do século XX na Itália, como resultado da modernização industrial e da massificação dos comportamentos, e justamente aquela que Pasolini criticou ao longo de sua trajetória intelectual, tal como veremos no último capítulo.

${ }^{99}$ PASOLINI, P. P., Um secolo di studi sulla poesia popolare. In: Passione e Ideologia, p. 158. 


\section{As referências poéticas de Pier Paolo Pasolini: de Dante a Gianfranco Contini}

Este capítulo se constrói a partir de dois conceitos fundamentais à noção pasoliniana de poesia (pensada como poesia crítica): a ideia de plurilinguismo e a de monolinguismo. Por plurilinguismo, Pier Paolo Pasolini entendia uma "mistura de linguagens", ou seja, uma mistura de estilos e léxicos, cujo efeito seria uma poesia realista, enquanto o monolinguísmo seria a separação dessas linguagens enquanto uma hierarquia lexical e estilística. Pasolini se vale da definição resgatada pela crítica literária italiana de seu tempo, através do trabalho de Gianfranco Contini em seu ensaio intitulado Preliminari sulla lingua del Petrarca (1951). Assim, entre as diversas referências mencionadas nos ensaios de Pasolini em Passione e Ideologia, serão privilegiados aqueles poetas cujos trabalhos foram submetidos à sua crítica levando em consideração dois conceitos mencionados. São eles Dante, Petrarca e Pascoli.

O que se percebe através da leitura desses ensaios é a tentativa pasoliniana de definir a poesia italiana por meio de duas matrizes selecionadas por ele: a monolinguista, cujo principal representante seria Francesco Petrarca e a outra, plurilinguista, representada pela poesia de Dante Alighieri. A poesia de Giovanni Pascoli, poeta do final do século XIX, por sua vez, foi entendida de certa forma como continuadora dessa ideia plurilinguista, por meio daquilo que nos ensaios foi definido como um "experimentalismo antitradicional", cuja definição também perpassa a ideia de uma "mistura de linguagens". A partir do que foi resumidamente exposto aqui, pode-se entender que o objetivo central desse capítulo é problematizar tal leitura de Pasolini, onde ele buscou forjar uma aproximação entre o estilo poético de Dante e o de Pascoli; esses em oposição a Petrarca.

Aquilo que Pasolini compreendia como sendo a tradição plurilinguista, iniciada por Dante, teria como um dos principais continuadores Pascoli e, logo em seguida, ele próprio. Fica claro também que a figura de Petrarca é colocada por ele no papel de opositora, como representante de uma tradição academicista, cuja 
tendência seria a de hierarquizar os léxicos e os estilos poéticos. Contudo, é importante salientar que esse dualismo não será sustentado por Pasolini - o que se verá na análise dos ensaios. O que permanece ao longo da ensaística pasoliniana é a sua clara admiração pela poesia tanto de Pascoli, quanto pela de Dante, não somente por admirar a "mistura de línguas", mas, principalmente, por vislumbrar nelas o caminho para a composição de uma poesia mais realista.

\subsection{Dante Alighieri e Francesco Petrarca: uma ideia de linguagem em oposição}

No ensaio Il reame, Pasolini apresenta os dois poetas como cânones da poesia moderna italiana, apropriando-se de uma ideia exposta por Gianfranco Contini em Preliminari sulla lingua del Petrarca. Seguindo um critério linguístico, Contini problematiza as análises que estabelecem uma distinção entre os poemas de Petrarca e de Dante segundo o critério monolinguista e plurilinguista, desqualificando essa definição por ser imprecisa e redutora. O problema desse tipo de reflexão, segundo ele, é o de desconhecer os aspectos pluri e até bilinguísticos existentes nas composições de Petrarca, por exemplo. Já a análise de Pasolini segue ignorando a pluralidade de aspectos pelos quais podem ser pensadas a poesia de ambos os poetas, resumindo a tradição poética moderna italiana em

(...) um cânone monolinguistico, complexo, de origem petrarquesca, e que veio a compor a constante mais típica da literatura italiana, rendida em parte à pressão daquele bilinguismo (forma estilística, contra a aparência que frequentemente, nos autores modernos são especialmente conscientes de pastiche, imediatamente, levantando os estratos baixos da língua) que é, por definição, uma reação antiacadêmica, e compõe aquela constante menor, mas quanto mais feliz força, que se origina da mais realista das obras poéticas italianas, a Divina Comédia ${ }^{100}$.

\footnotetext{
100 “(...) Um canone monolinguistico, complesso e mediata, di origine pertrarchesca, e venuto a comporre la costante più típica della letteratura italiana - cede in parte alle pressioni di quel bilinguismo (forma stilististca, contro le apparenze che spesso, in autori coscienti specie moderni, sono di "pastiche", imediata, lienitante dagli strati bassi della lingua) che è per definizione una reazione anti-accademica, e compone quella costante minore, ma quanto più felice, forse, che si origina dalla più realística dele opere poetiche italiana, la Divina Commedia " (PASOLINI, P. P., Il reame. In: Passione e Ideologia, p. 12).
} 
Fica claro também que a Pasolini a poesia de Dante era a que melhor identificava uma noção mais realista, fugindo de uma perspectiva monolinguística e academicista, cujo representante primordial era Petrarca. Há, portanto, uma clara identificação de Pasolini com a noção de poesia em Dante, tal como ele a interpretou, elegendo a Divina Comédia como a obra poética "mais realista". No período da escrita de $I l$ reame (1955), ele identificava o poeta florentino como defensor de um estilo antiacadêmico.

\subsubsection{Dante Alighieri: entre o pluri e o monolinguismo}

Dante se configurou como uma importante matriz teórica da poesia em língua vernácula, visto que além da dimensão fundadora da Divina Comédia - que elevou Dante ao estatuto canônico - escreveu também tratados sobre a escrita poética, como o Convívio e De Vulgari Eloquenti, defendendo o uso do italiano em estilo elevado (definido como "vulgar ilustre"), que, como veremos mais frente, é um amalgama de vários dialetos italianos. É sobre esses temas concernentes à obra dantesca que esse subcapítulo tratará e como, a partir deles, uma determinada noção de poesia foi desenvolvida até chegar a Pasolini. Entre os aspectos que tornam a poesia dantiana semelhante àquela que Pasolini teria desenvolvido estão a dignidade dada ao vernáculo como língua natural (e divina), além de uma noção de poesia realista, pautada na experiência da vida terrena. Esses elementos teriam sido resgatados e usados por Pasolini à sua maneira em defesa da poesia dialetal italiana como língua natural poética.

Com a leitura dos tratados que constam em De Vulgari Eloquentia, é possível compreender quais foram os motivos que levaram Pasolini a admirar a noção que Dante construiu sobre poesia vernacular. Essa obra é o resultado inacabado dos estudos dantianos sobre as línguas vulgares italianas, onde ele sistematizou os temas que já se encontravam presentes no Convívio. Em seu tratado Dante procurou entre os vernáculos aquele que mais se aproximava do que, ao longo de sua exposição, definiu como sendo a mais nobre dentre as línguas vulgares. Ele conclui que o falar mais altivo não poderia ser encontrado em uma língua específica, mas em algo comum a todos os falares da Itália e a partir de uma junção entre esses definiu o "vulgar ilustre”. Assim surgia, já no 
século XIV, na Itália a ideia de uma língua italiana decorrente de uma mistura de linguagens.

No entanto, antes de discorrer sobre a importância de Dante para as concepções poéticas pasolinianas, é importante apresentar o tratado e seus desdobramentos, a fim de compreender qual foi o Dante que Pasolini leu. De Vulgari Eloquentia começa com Dante definindo o que entendia por vernáculo, “aquela língua à qual as crianças são acostumadas pelos que as rodeiam tão logo começam a articular distintamente as palavras"101. A este tipo de língua, tida por ele como natural soma-se uma outra, a gramática (tida por ele como artificial), que para ser apreendida e aprendida necessita de "tempo e perseverança nos estudos", e da qual não faziam uso todos os povos. Justamente pelo caráter natural da primeira é ela, na concepção dantiana, a "mais nobre":

A mais nobre entre estas duas é o vernáculo, seja por ter sido a primeira a ser empregada pelo gênero humano, seja por dela valer-se o mundo inteiro (mesmo na diversidade de pronúncias e de vocábulos que a dividem), seja porque nos é natural (enquanto a outra é assaz artificial) ${ }^{102}$.

Para Dante o fato de os homens serem movidos pela razão e não por instintos tornava necessário e natural o uso da língua. A razão tornou os homens diferentes entre si, "em termos de discrição, juízo e escolha”, sendo impossível, portanto, o entendimento entre eles somente pelos instintos. Era primordial a existência de um signo comum, capaz de ser entendido por todos através dos sentidos humanos (audição, visão, etc). Desse modo, por ser a língua uma necessidade instintiva entre os homens, e terem eles os meios naturais de pronunciá-la, não é forçoso afirmar que a língua nasceu concomitantemente ao primeiro homem, Adão, sendo um atributo dado a este por Deus. É essa a perspectiva adotada por Dante quanto à origem da primeira língua. Ele vai até as Sagradas Escrituras e contraria a informação contida no Gênesis - aquela que atribui a Eva a pronuncia da primeira palavra. Era impensável a ele que "tão excelente ato do gênero humano precedesse não um homem, mas uma mulher". Quanto à primeira palavra proferida por Adão é evidente para ele ser o

\footnotetext{
${ }^{101}$ DANTE, A., De Vulgari Eloquentia, Livro Primeiro. p. 3.

${ }^{102}$ Ibid., p. 3.
} 
equivalente a Deus na língua adâmica, pois era absurdo a Dante o primeiro homem nomear qualquer coisa antes de Deus ${ }^{103}$.

Se a língua foi concedida por Deus aos homens, por que, então, ela diversificou-se ao longo do tempo? Sobre esse tema Dante desenvolveu o capítulo VII do primeiro livro do tratado, justificando seus argumentos a partir do episódio bíblico da construção da torre de Babel (definida por ele como a "torre da confusão"):

\begin{abstract}
Para cumprir esta obra perversa encontrava-se reunido quase todo gênero humano: uma parte chefiava os trabalhos, uma parte dirigia a arquitetura, uma parte erguia os muros, uma parte os nivelava (...). Foi quando do Céu foram infligidos com uma tal confusão que, enquanto antes se aplicavam a esta obra empregando uma única e idêntica fala, se viram diferenciados em numerosas línguas e tiveram de renunciar à empreitada, nunca mais logrando o mesmo acordo numa atividade comum(...). O número de línguas nos quais o gênero humano se dividiu neste momento era igual àquele das várias atividades: quanto mais elevada havia sido a função de cada grupo, tanto mais rude e bárbara foi a língua que lhes coube. A língua sagrada permaneceu entre aqueles que não participaram dos trabalhos nem os aprovavam (...) Pelo que conjecturamos, pertencia a esta parte, que em número ou proporção mínima, a estirpe de Sem, o terceiro filho de Noé: precisamente desta nasceu o povo de Israel ${ }^{104}$.
\end{abstract}

Portanto, de um castigo divino à audácia dos homens em construir uma torre para alcançar os céus, a língua humana foi multiplicada, impossibilitando a comunicação entre todos os homens. A língua original, de Adão, não se perdeu, tampouco permaneceu entre aqueles que cometeram o pecado e foram castigados. Para Dante, a língua adâmica fundou e continuou entre os hebreus até a sua dispersão, séculos depois.

A partir dessa constatação, Dante poderia dar continuidade aos seus estudos, rumo ao objetivo principal de seu tratado que, conforme foi informado anteriormente, era o de encontrar a língua vernácula mais nobre, ou seja, a mais próxima da primeira língua. Se o hebraico, como ele mesmo afirmou, perdeu-se após a dispersão do povo de Israel, qual seria o caminho em busca do vocábulo mais nobre? Segundo ele, após o castigo de Babel ocorreu a migração de alguns povos e suas variedades linguísticas a algumas regiões da Europa, entre elas uma

\footnotetext{
${ }^{103}$ Ibid., p. 5.

${ }^{104}$ Ibid.., p. 13.
} 
unidade que se tripartiu dando origem às línguas das regiões da Itália, Espanha e França. A partir dessa determinação, ele indaga quais foram os motivos que levaram a essa tripartição e, por sua vez, por que dessa tripartição surgiram variações linguísticas (vernáculos) como as encontradas na região italiana, por exemplo. Sobre esses questionamentos, Dante concluiu:

Se (...) uma língua varia de um mesmo povo com o passar do tempo, e não pode de maneira alguma manter-se imóvel, as línguas de populações que vivem separadas e distantes devem necessariamente alterar-se de maneiras diversas, como de diversas maneiras mudam os usos e costumes destas populações, os quais não são estáveis a causa da natureza ou da sociedade, mas ao contrário nascem como frutos do arbítrio humano e com base em critérios de proximidade espacial ${ }^{105}$.

As conclusões de Dante quanto à variedade da língua permitem entender o que ele compreende por "língua natural", que possuiria a capacidade de variar no tempo e no espaço. Se a língua era justamente o reflexo das necessidades humanas, como poderia ela não sofrer essas alterações? Contra esse processo de mutação inerente aos falares os homens teriam inventado a gramática, "uma língua inalterável e sempre idêntica", capaz de fixar regras, mas que, por outro lado, artificializava os idiomas ${ }^{106}$. Como o que Dante pretendia era analisar e descobrir a língua mais próxima à original, seu postulado era o de questionar a gramática, e dedicar-se a análise dos vernáculos, já que estes mantinham intactas a capacidade de variação histórica.

Desse modo, Dante retoma no capítulo $\mathrm{X}$ a discussão sobre as línguas vernáculas, especificamente entre aquelas que se originaram na Europa a partir da tripartição das línguas, elegendo os idiomas falados na Itália como mais próximos da unidade linguística original. O critério para tal definição esbarra na questão da poesia. Apesar de o tema da obra ser a defesa do uso do vernáculo em poesia, é a primeira vez no tratado que Dante faz menção ao tema, ao defender que

a terceira língua, aquela dos italianos, afirma sua superioridade com base em duas prorrogativas: primeiro, que são seus amigos e ministros aqueles que mais docemente e sutilmente compuseram poemas em vernáculo, como Cino da Pistoia

\footnotetext{
105 Ibid., p. 14.

${ }^{106}$ Ibid., p. 13.
} 
(...); segundo, porque estes mostram apoiar-se mais que quaisquer outros sobre a "gramática" que é comum a todos"107.

Aquilo que Dante entendeu como "gramática comum a todos" pode ser lido como os vocábulos italianos comuns a todos os idiomas pronunciados na região, e não a gramática que os artificializa.

Contudo, onde fica a questão da poesia no tratado dantiano? O poeta de forma alguma ignora a importância da poesia, visto que, como foi determinado anteriormente, esse é o tema central de seu tratado. O critério pelo qual Dante vai em busca do seu vernáculo nobre é justamente seu uso em escritos poéticos, e que se torna claro a partir da leitura de Vulgari Eloquentia ao longo dos capítulos subsequentes. Neste momento é necessário pontuar o que o poeta entendia como "vulgar ilustre", e no que esse se relaciona à poesia:

Ora, o vernáculo do qual tratamos é sublimado pela doutrina e pelo poder, elevando seus cultores com honra e glória. Que seja sublimado pela doutrina é evidente: com efeito, a partir de tantos rudes vocábulos dos italianos, de tantas construções intrincadas, de tantas formas errôneas, de tantas pronúncias rurais, emerge um vernáculo tão excelente tão límpido, tão perfeito e tão urbano como aquele exibido nos poemas de Cino de Pistóia ${ }^{108}$.

Dante conclui o Primeiro livro de seu tratado defendendo a superioridade de um vernáculo italiano (comum à toda Itália), justificando através das dignidades de tal vernáculo (ser ilustre, cardeal, cortês e crucial) os motivos de tal superioridade. O sublime vernáculo italiano, portanto, era aquele pronunciado pelos ilustres mestres da Itália, sejam eles toscanos, sicilianos, lombardos ou qualquer outra origem. Repare, portanto, que a excelência provém da diversidade, do encontro do urbano e do rústico, do límpido com o errôneo, por exemplo. No segundo livro, inacabado, ele prometia desenvolver os preceitos para o uso da língua ilustre, a começar pelo emprego do vernáculo em poesia.

No primeiro capítulo do segundo livro, Dante defende que o ilustre vernáculo é passível de ser usado para textos em prosa e poemas, o que, no entanto, não excluía a superioridade do uso de uma língua em poesia. Assim, suas reflexões encaminham-se ao principal objetivo, que seria o de conferir dignidade

\footnotetext{
${ }^{107}$ Ibid., p. 15.
}

${ }^{108}$ Ibid., p. 23. 
ao vernáculo ilustre através da defesa das composições poéticas. Ele também defendeu o uso desse em versos rudes, de forma a elevar o valor dessas composições:

(...) não somente agiria bem um versejador, mesmo autor de versos rudes, que misturasse aquele vernáculo ilustre à sua rudeza, mas também estaria cumprindo um dever: afinal, os poucos dotados necessitam de mais ajuda que os capazes. Mostraria-se então claro como a todos os versejadores seja lícito usar o vernáculo ilustre $^{109}$.

Contudo, ele nega tal afirmativa. Para ele, o uso de uma língua ilustre na composição de versos rudes levaria os mesmos ao ridículo. Mas, o que teria levado a essa mudança de opinião tão imediata em Dante? Uma hipótese provável seria a do caráter educativo no qual De Vulgari Eloquentia foi elaborado. É possível que esse tratado tenha sido escrito não somente para valorizar o vernáculo como digno de produzir poesia, mas também no sentido de ser essa poesia a mais sublime, sendo digna de ser estudada e lida ${ }^{110}$. Essa hipótese se torna coerente quando se pensa no caráter educativo presente de maneira explícita no Convívio.

O fato é que Dante continuou a sua exposição em defesa do uso do vernáculo ilustre, afirmando a importância de fazerem uso dele somente aqueles que possuíam mérito e excelência para tal:

Declaramos que seja meritável o que possui mérito, como é nobre o que possui nobreza; e se conhecido um costume conhece-se quem detenha o mesmo, pela conformidade do primeiro ao segundo, sabendo do mérito saberemos do que é meritável. O merecimento é o efeito, o termo das ações empreitadas; (...) É assim manifesto como os méritos possam ser confrontados com base no mais e no menos, de maneira que alguns resultem grandes, outros maiores e outros ainda grandíssimos (...) Entende-se assim como o que é excelente é necessariamente digno do que há de mais excelente e assim, tendo chamado de ilustre ao mais excelente entre os vernáculos, entende-se como somente os argumentos mais nobres mereçam tal vernáculo, sendo estes aqueles que, na escala de argumentos que podem ser tratados, chamamos de meritabilíssimo (...) Portanto são estas três(...) que merecem serem tratados nas formas mais excelentes, pelos

\footnotetext{
${ }^{109}$ Ibid., p. 27.

${ }^{110}$ Eloquentia, segundo Dante, era a arte de exprimir-se em vernáculo tanto em prosa quanto em poesia. Ver: DANTE, A., De Vulgari Eloquentia, p. 48. Notas do tradutor.
} 
argumentos a ela relacionados: o valor nas armas, o ardor no amor e o controle da própria vontade ${ }^{111}$.

Amor, guerra e virtude são os temas dignos de serem versados em vernáculo ilustre. O próximo passo foi, então, eleger a canzone como a melhor forma para serem escritos esses poemas. Para ele, essa seria a forma métrica superior já que "apesar de tudo, quando exprimimos em versos ser uma canção, somente à forma dita "canção" coube tal nome"112. Além disso, ela teria uma "força interior", não precisando de algo que atue em seu nome, como também compor canções traria mais honras a seus respectivos autores do que outras formas métricas usadas em poemas. Por fim conclui que a canzone contempla toda as técnicas poéticas existentes, o que não ocorreria em outras formas métricas.

No capítulo IV, o poeta continua suas reflexões, partindo para a hierarquização dos vernáculos. Além do ilustre, nesse capítulo Dante fala de outros, como o mediano e o humilde, os quais ele pretendia melhor aprofundar-se nos livros que anunciou, mas não escreveu. Essa hierarquização tinha em seu tratado o intuito de organizar a escrita de acordo com a matéria a ser tratada no poema: a forma trágica deveria ser escrita no estilo superior, o vernáculo ilustre; a comédia deveria assumir ou o vernáculo mediano ou talvez o humilde e, por fim, ao elegíaco, só caberia o vernáculo humilde ${ }^{113}$.

Mais uma vez em seus escritos, Dante adota uma postura que se vale de preceitos da Antiguidade Clássica para organizar seu tratado de escrita poética. A diferença entre o que Dante propõe aqui e o que a maioria dos poetas de seu tempo fazia é que ele defende todas essas regras para uma escrita em vernáculo ilustre, enquanto normalmente essas regras valeriam na Idade Média à escrita em latim.

Outros aspectos da poesia ilustre, como a metrificação e o vocabulário, são analisados nos capítulos subsequentes. Ele inicia o capítulo VIII definindo o que entendia por "canção". Primeiramente ele tenta definir se ela é ativa ou passiva:

\footnotetext{
${ }^{111}$ Ibid., p. 27 e 28.

${ }^{112}$ Ibid., p. 27.

${ }^{113}$ Ibid., p. 31.
} 
Portanto vejamos o que é canção e o que entendemos por este termo. A canção, segundo seu significado autêntico, nada mais é que a ação do cantar em sentido ativo ou passivo (...). Estabelecendo a distinção entre os dois ramos desta definição, devemos analisar se neste caso o termo esteja entendido em sentido ativo ou passivo (...) No primeiro, enquanto algo construído por seu criador, a "canção" é entendida em sentido ativo: é nesta acepção que Virgílio, na abertura de Eneida, diz Arma virumque cano, no segundo sentido, enquanto algo construído anteriormente, a "canção" é declamada por ser autor ou por outra pessoa (...) E visto o operar sobre a canção ser anterior ao operar da mesma, parece-nos apropriado que sua denominação derive do ser obra de alguém e não do ser obra em alguém ${ }^{114}$.

Dessa forma, Dante determina um sentido ativo da canção, pois, conforme ele mesmo afirmou “(...) enquanto algo construído por seu criador, a "canção" é entendida em sentido ativo"115. No entanto, o aspecto mais importante de uma canzone parece ser o seu encadeamento, que, segundo Dante, deve ser feito em "stanze iguais", ligadas por um único pensamento do início ao fim do poema. Nos últimos capítulos do segundo livro, Dante analisa as composições, a métrica e a disposição dos versos endecassílabos da canção, do número de sílabas dos versos, entre outros aspectos técnicos do que ele considera ser a escrita poética mais adequada do vulgar ilustre mas que, entretanto, não são importantes ao presente trabalho. O que importa aqui, principalmente, é perceber como o autor realiza uma ode ao vernáculo ilustre sem, no entanto, abrir mão de critérios como a métrica, o tema e a forma, para assim elevar o vernáculo nobre à mesma categoria das poesias escritas em latim, relegando aos vernáculos menos ilustres determinados temas e formas de composição. Dante faz uso referências clássicas, como Aristóteles, citado logo no início do tratado.

Outro importante ponto presente tanto em De Vulgari Eloquentia quanto no Convívio é o caráter educativo que ele entende ser a função essencial das canzoni vulgares, sendo por isso também necessário que ela fosse escrita em línguas vernáculas, visto que o latim restringia o acesso da escrita e da leitura aos grupos que dominavam aquela língua. É importante também serem os motivos nobres, assim como a forma e métrica, pois assim aqueles dariam àqueles que tinham acesso a tais canções, uma educação ilustre, típica de homens nobre e ilustres.

\footnotetext{
${ }^{114}$ Ibid., p. 38.

115 Ibid., p. 38 e 39.
} 
Além do caráter educativo da obra, não se pode deixar de observar o caráter moral que o Convívio adquire, principalmente quando se leva em consideração a questão da fragmentação da língua adâmica em diversas outras como resultado da insensatez dos homens em tentarem se igualar a Deus na construção do edifício de Babel. Não existia, portanto, uma sociedade digna de portar a língua ilustre desde a dispersão dos hebreus. A procura de Dante pelo vulgar ilustre pode ser definida como uma busca pela moralização entre os homens, visto que tal vulgar se encontrava aos pedaços, presente em diversas línguas. Em Dante, a sabedoria é o caminho à razão, e são essas duas juntas que conduzem a uma vida virtuosa e lança os homens para o bem. Nesse sentido, é possível vislumbrar nas duas obras analisadas acima uma conexão e uma linha de pensamento que conduz à Divina Comédia.

Longe de querer colocar os tratados dantescos como secundários em relação à produção da Comédia - já que eles possuem seu valor como obras individuais - é impossível não pensar que a trajetória do personagem Dante do Inferno ao Purgatório, conduzido pelo sempre citado poeta Virgílio, não esteja relacionada ao que o autor expôs nas duas obras anteriores. A relação que ele estabeleceu entre o latim e o italiano vulgar, quanto às regras clássicas de produção poética, são confirmadas na Comédia a partir do que se pode definir (da perspectiva pasoliniana) como uma "mistura" de linguagens e estilos. A poesia é representada através da figura de Virgílio na Comédia como o caminho ao Paraíso, símbolo da razão. Ela era, assim, o caminho à razão e, consequentemente, da salvação.

Na Comédia, Dante mistura elementos clássicos da poesia sublime e da baixa, misturando a narrativa da vida de personagens inferiores (principalmente no Inferno), mas também de personagens superiores (no Paraíso) fazendo uso de um estilo elevado, e escrito em italiano. Tal idioma era composto por uma mistura de línguas vernáculas, que o autor promoveu em sua busca pelo vernáculo ilustre e que, mais tarde, se concretizou como o linguajar por excelência da Itália. Dante 
trabalhou em cima das regras clássicas de composição poética, porém, operou sobre elas a sua "mistura de linguagens", dando-lhes uma nova feição ${ }^{116}$.

A intenção de Dante não aparenta ser romper de modo radical com as regras básicas da composição poética, no sentido de negar a distinção entre personagens ilustres e vulgares, mas sim demonstrar de que forma personagens ilustres poderiam guiar aqueles homens vulgares (pecadores, por exemplo) em seu caminho rumo à sabedoria e à razão. Desse modo, o caráter didático permanece presente na Comédia. Para além do caráter didático, que se encontra presente tantos nos tratados dantescos quanto na Comédia, a valorização do vulgar levou, portanto, à formação do italiano, alçando Dante à categoria de cânone, bem como ao papel de construtor da língua italiana.

Por sua importância na história do pensamento ocidental, a obra de Dante já foi examinada por diversos pensadores, sendo um dos mais importantes e recentes, Erich Auerbach, autor de diversos trabalhos sobre o pensador florentino, e cuja obra é de suma importância para a compreensão do modo pelo qual a obra dantesca foi lida por Pasolini no século XX, já que há muitos pontos de convergência entre a interpretação de ambos os autores sobre a obra Dante ${ }^{117}$. Os textos fundamentais de autoria de Auerbach que serão aqui analisados são: Dante, o poeta do mundo secular, Introdução aos estudos literários e Mimeses.

\footnotetext{
116 Para Aristóteles, a poesia era evidentemente ligada à ideia de imitação. A partir disso, havia uma clara distinção quanto às regras poéticas para a composição de poemas no gênero trágico, a epopeico e a cômico. A tragédia, para ele, deveria ser a imitação de ações ilustres, de personagens ilustres, "seres melhores que nós", que geravam nas pessoas determinadas características, principalmente temor ou pena. Ação narrada na tragédia deveria ser acabada, tendo início, meio e fim, representando não necessariamente a verdade, mas algo realmente possível. A extensão conveniente da tragédia deve ser o suficiente "que a memória possa abranger inteira". A linguagem da tragédia deve ser aquela que "prega termos surpreendentes", ou seja, "termo raro, a metáfora, o alongamento e tudo o que foge ao trivial". A epopeia, outro gênero poético elevado, dever ter as mesmas espécies que a tragédia, diferente somente pelo tamanho e por ser nela permitido o uso do irracional (que na concepção aristotélica era a condição principal do maravilhoso). Quanto à comédia, Aristóteles define que ela é a imitação de seres inferiores, "não por todo vício, mas sim por ser o cômico uma espécie de feio. A comicidade, com efeito, é um defeito e uma feiúra sem dor nem destruição. Tanto uma quanto a outra imitam os homens de maneira mais exacerbada do que eles são; a tragédia os imita melhores, e a comédia piores. Ver: ARISTÓTELES; HORÁCIO e LONGINO. A poética clássica. São Paulo: Cultrix, 2005.

${ }^{117}$ Segundo a interpretação de Georges Didi-Huberman, a leitura que o jovem Pasolini faz acerca de Dante é intermediada pela "descoberta dessa história da mimesi literária que Erich Auerbach problematizou em seu ensaio magistral sobre 'Dante poète du monde terrestre' ". Ele se refere ao texto (traduzido para o português) Dante, poeta do mundo secular. Ver: Didi-Huberman, G., Sobrevivência dos vagalumes, p.15.
} 
Em Dante, o poeta do mundo secular, Auerbach nos apresenta a trajetória de Dante como poeta medieval até a composição de sua obra canônica, a Divina Comédia. A primeira poesia dantesca se desenvolveu a partir de um movimento que surgiu na Itália através de Guido Guinizelli - bolonhês percursor de um novo estilo de poesia italiana, inspirada na poesia provençal - de onde o jovem Dante deu origem às suas atividades poéticas. Surgiu assim o dolce stil nuovo, definido por Auerbach como “(...) uma poesia altamente estilizada, veículo de uma forma seleta e aristocrática de vida e hostil à expressão vulgar”. A escrita característica do novo movimento utilizava uma língua vernácula em um estilo grandioso, coisa muito rara naquele momento na região da Itália, cuja linguagem mais comumente utilizada era um latim (definido por Auerbach como "um latim senil"); o "vulgar ilustre" dava ainda os seus primeiros passos, tendo nos escritores do dolce stil nuovo importantes construtores da língua italiana ${ }^{118}$.

A influência do Stil Nuovo foi muito importante a Dante, principalmente a poesia de Guido Cavalcanti, seu grande mestre. Nas obras e tratados dantescos também é frequente a referência ao estilo de Cino de Pistóia ${ }^{119}$. No entanto, o estilo pessoal de Dante já se destacava desde o início de suas primeiras poesias. Auerbach define a poesia de dantesca em sua fase inicial como "visionária", principalmente pela capacidade do poeta em transformar os temas de seus poemas em uma realidade histórica concreta ${ }^{120}$. Dando destaque à poesia dantesca frente a outros poetas do mesmo período, Auerbach apresenta um Dante que conseguiu tornar-se único, mesmo ao fazer uso de elementos já existentes em outros poetas:

O estilo de poesia de Dante na sua primeira fase é mais rico que o de seus predecessores. É mais restrito, no sentido de adesão a um tema do começo ao fim do poema. Esse método, que tem um efeito de realismo e proximidade mesmo quando são tratados temas audaciosos ou pouco usuais, não era nada de novo.

\footnotetext{
118 AUERBACH, E., Dante, o poeta do mundo secular, p. 41-43. O que Dante entende como "latim vulgar" trata-se do latim falado, que deu origem às diferentes línguas românicas, sendo essas também definidas como vulgares durante muito tempo em função de sua origem. O latim vulgar, portanto, é aquele que foi submetido ao processo de historicidade e do contato com as línguas dos povos que entravam em contato com os romanos. AUERBACH, E., Introdução aos estudos literários, p. 49-50.

${ }^{119}$ Guido Cavalcanti: poeta natural de Firenze, pertencente a uma rica família da região. Não se tem a noção exata de quando Guido nasceu, mas em função de sua entrada no Conselho geral da sua comuna (cuja exigência era que os membros tivessem a idade de 25 anos), supõe-se que ele deva ter nascido por volta de 1258 . As principais informações sobre a biografia desse poeta estão nos textos dantianos. Já Cino de Pistoia (nascido talvez em 1270), foi um jurista e poeta. Ver: http://www.treccani.it/enciclopedia/guido-cavalcanti res-a5c34b2d-bf12-11df-8656$005056 \mathrm{~b} 3532 \mathrm{f}$ (Dizionario-Biografico)/.

${ }^{120}$ AUERBACH, E., Dante, o poeta do mundo secular, p. 60, 62
} 
Era, ao contrário, conhecido havia muito tempo, se bem que não no estilo sublime. Temas canônicos, pastorais ou polêmicos eram tratados assim muitas vezes. Havia uma inclinação natural nesse sentido na Itália (...) Mas antes da época de Dante esse procedimento não fora adotado na poesia vernácula mais fina ${ }^{121}$.

Desse modo, muitos temas da poesia que Dante compunha, e que o tornava singular entre os poetas de seu tempo, o aproximavam de um tipo de poesia que era comumente composta em estilo baixo, mas que ele inovou ao escrever em vernáculo ilustre. Dante não abandonou o estilo elevado - como pode ser entendido a partir de seus tratados poéticos - somente os misturou com elementos de poesias consideradas inferiores, como a composição de poemas com apenas um tema, porém em vernáculo ilustre. Auerbach atribuiu justamente ao uso de um único tema a excepcionalidade do realismo dantesco visto que o poeta se aprofunda mais no tema e "organiza-o de dentro para fora"122. Além do constante uso do poema ilustre em língua vernácula, portanto, o stil nuovo demonstrou, através de Dante, um novo tom dentro de um estilo considerado sublime, que até então definia-se por suprimir a realidade em nome de uma retórica. Dante afastava-se de uma concepção poética típica da Idade Média, pois, segundo Auerbach, valorizava acima de tudo a realidade e os sentimentos, o que dava um tom mais natural às suas composições.

Dante preocupava-se sobretudo com o conteúdo didático de seus escritos, e tal característica perpassa a construção da sua noção de realismo, segundo Auerbach. Essa preocupação também é perceptível a partir do exame de tratados como Convívio e De Vulgari Eloquentia, que, antes de pretender discutir a eloquência das línguas vernáculas, preocupava-se em determinar um modo de transmitir conhecimento. $\mathrm{O}$ apelo que ele faz aos nobres no Convívio, para que estes alimentassem aqueles que precisavam do alimento ( o conhecimento), somava-se ao fato de ser este tratado escrito em italiano, de forma a se tornar acessível a um maior número de pessoas, visto que o latim era dominado por um grupo muito seleto. Mesmo em De Vulgari Eloquentia - cuja escrita foi toda em latim - havia ali uma sistematização daquilo que havia sido antes desenvolvido no

${ }^{121}$ Ibid., p. 64

${ }^{122}$ Ibid., p. 64 
Convívio: uma demonstração do caráter ilustre e nobre dos vernáculos, tão dignos da poesia mais nobre quanto qualquer poema em latim produzido naquele período.

Para Auerbach, o caminho percorrido por Dante - já perceptível no Convívio e chegando à Comédia - significava um movimento em direção não somente da valorização do vulgar, mas,

(...) um apelo ao povo, que era o principal esteio da nova cultura europeia. Daquele momento em diante, as obras fundamentais a que a vida cultural europeia iria dever seu desenvolvimento seriam escritas nas diversas línguas vernáculas, para o público que Dante tinha em mente. Elas tiravam sua vitalidade e expressividade da língua nativa de cada escritor, fosse ela qual fosse; mas tinham, todas, uma coisa em comum, a concepção de um volgare ilustre, i.e. de um vernáculo nobre: um idioma literário, que mantém um constante toma lá dá cá com a linguagem do uso diário e se constitui, assim, em elemento vivo no pensamento e na tradição (...) que está à disposição de todos os que por ela se interessem (...) Embora pareça difícil definir o espírito do volgare ilustre, talvez possamos dizer que o novo idioma incorpora um desejo de conhecimento como arma para a conquista do mundo $(\ldots)^{123}$.

O objetivo didático de Dante mistura-se a uma escrita que preconizava ser o mais racional e objetiva possível. Nesse intuito, ele analisou sistematicamente a língua, conseguindo, assim, atingir uma "pureza de estrutura lógica, articulação clara", que foi expressa na obra incompleta, Convívio ${ }^{124}$. Auerbach identifica em Dante, durante o período de elaboração desse tratado, um momento de transição, que mais a frente resultará na Comédia, e que é largamente explorada pelo comentador alemão em diversos textos dedicados à obra canônica. Como tal exposição seria extensa para os fins desse capítulo, será melhor encurtá-la, indo direto ao que motivou a leitura da obra auerbachiana: uma interpretação acerca da noção de realidade expressa em Dante Alighieri, que será o ponto de partida para pensar, por sua vez, a noção de realismo defendida por Pasolini, ou seja, uma noção de realismo como uma experiência sensível da realidade.

A noção de realidade dantesca é perceptível para Auerbach na estrutura da Comédia. Adotando uma concepção menos presa à mimesis aristotélica e mais próxima à cultura medieval Dante encontra um estilo pessoal que confere aos personagens do poema uma essência pautada na experiência. Assim, o realismo dantesco deu aos seus personagens uma vida pautada nas próprias experiências do

\footnotetext{
123 Ibid., p. 100

${ }^{124}$ Ibid., p. 101.
} 
poeta, que se refletem no desenvolvimento da composição. Em Farinata $e$ Cavalcanti, Auerbach deu uma definição mais clara do que entendia o realismo que Dante assumiu na Comédia:

\begin{abstract}
Imitação da realidade é a imitação da experiência sensível da vida terrena, a cujas características essenciais parecem pertencer a sua historicidade, a sua mutação e ao seu desenvolvimento; por mais liberdade que se queira dar ao poeta imitativo para a sua criação, esta qualidade, que é a sua própria essência, ele não deve tirar da realidade ${ }^{125}$.
\end{abstract}

De acordo com aquilo que defendeu Auerbach em sua interpretação, reside no realismo em Dante o tema de maior interesse desse trabalho que vem sendo desenvolvido. Através da leitura empreendida por Erich Auerbach, é possível identificar elementos similares entre a ideia de realismo presente no pensador florentino e a que Pasolini vai construir ao longo de sua trajetória intelectual, vinculada aos dialetos.

O realismo dantiano, conforme foi explorado até aqui, passa por uma profundidade com a qual o poeta mergulha no tema de seus poemas, tornando seu texto mais natural. Um elemento importante que Auerbach explora em Dante, o poeta do mundo secular é o fato de a construção da realidade nas obras dantianas estarem vinculadas a uma referência que o poeta faz dos elementos da Antiguidade. Portanto, na visão auerbaquiana, nos poetas da Antiguidade residem a razão presente em Dante, o que explica as referências feitas pelo poeta a Virgílio, supracitada nesse capítulo. A novidade do poeta, portanto, não estaria tanto no fato dele inovar em termos de uma construção poética - ao menos como ele é apresentado em sua primeira fase como poeta - mas sua capacidade de, a partir de ideias já existentes na Antiguidade, por exemplo, conceder uma nova força ao poeta, apropriando-se de elementos e conferindo-lhes uma nova marca.

A imitação que Dante defendia na Comédia, pela interpretação auerbachiana, em verdade não era a da realidade possível, mas daquilo que o mais próximo poderia ser desta. Talvez essa característica esteja relacionada à opção do poeta em escrever uma obra cujo personagem principal era ele próprio, colocando o protagonista da narrativa em situações relacionadas a sua própria experiência.

${ }^{125}$ AUERBACH, E., Mimesis: a representação da realidade na literatura ocidental, p. 166 
Ainda quanto à realidade vinculada à ideia de imitação, os três estágios em que a história se passa contemplariam a realidade. Além disso, pela enumeração de elementos dos cenários descritos no poema, Auerbach apresenta um conjunto de elementos antitéticos, entre eles passado, presente, o sublime e o desprezível, tragédia e comédia. Entre esses opostos, Dante abarcou todos os outros elementos possíveis em uma existência real que se refletiu nos caminhos do protagonista homônimo que ele criou em sua jornada rumo ao Paraíso.

Assim, pode-se concluir que leitura feita por Auerbach do realismo dantesco na Divina Comédia é vinculada a uma ideia de experiência, sendo a própria experiência pessoal de Dante um tema essencial ao poema. Aquilo que o Dante do poema vivencia nas ações que são narradas nada mais representam que a reelaboração poética de suas experiências terrenas e é justamente isso que a interpretação auerbachiana leva a entender. $\mathrm{O}$ cuidado que o poeta tinha em se dedicar a um único tema, bem como sua preocupação com a descrição dos acontecimentos, demonstra uma preocupação com o realismo de seu poema, o que justificaria a leitura feita pelo seu comentador.

\subsection{A crítica de Croce a Dante Alighieri e a Giovanni Pascoli}

A crítica de Benedetto Croce constitui-se importante referência ao fazer poético de Pasolini, tamanha a relevância de seus estudos para a crítica literária italiana contemporânea e a variedade de temas dos quais Croce tratou ao longo de sua trajetória. Desse modo, nesse subcapítulo trataremos da leitura que Croce fez de dois poetas, Dante Alighieri e Giovanni Pascoli. A leitura da obra de Croce justifica-se na análise desse capítulo em virtude da importância do autor para a crítica literária italiana, como visto no capítulo anterior.

Seguindo uma organização cronológica, o primeiro texto croceano que será analisado é seu trabalho acerca da obra de Dante, intitulado La poesia di Dante (1921). Já na introdução, Dante é apresentado como um "homem de ação, participando a seu modo da crise italiana e europeia entre o final do século XIII e 
início do século XIV" ${ }^{126}$. No entanto, para Croce, a maior importância do florentino reside em sua atuação como poeta; é essa atuação que o faria ser um pensador tão considerado em campos como a religião, a política e a filosofia. A interpretação de Croce se mostra, desde o princípio, um esforço para diferenciar Dante dos demais poetas de seu tempo. Em uma passagem da introdução, ao analisar a diferença entre a interpretação filosófica e a poética, ele atribui uma distinção à poesia dantesca, a partir da noção de "allotria", definida no texto como “intuição poética”. Esta intuição seria muito melhor entendida por Dante, se comparado ao trabalho dos outros poetas, onde ela era negligenciada ${ }^{127}$.

O trabalho de Dante foi muito relevante para estudos sobre poesia, sobretudo pelo movimento romântico, sendo tema de muitos trabalhos de pensadores italianos e estrangeiros durante o século XVIII. São muitas as possibilidades de estudo sobre a obra dantiana, visto a complexidade de seu trabalho, mas também são muitas as lacunas que os estudos deixam sobre o conjunto de sua obra. Croce cita, por exemplo, a questão de alegoria dantesca, e afirma que tal noção não teria sido claramente expressa pelos seus estudiosos, em virtude da ausência de uma definição do autor acerca desse tema. O grande erro dos intérpretes de Dante, segundo Croce, é o de quererem achar um significado oculto da sua obra, e muito desse erro está relacionado à supervalorização de inúmeras facetas dantianas (poeta, filósofo e político). Um exemplo disso seria o tratado De Vulgari Eloquentia, em que,

(...) notável, como certamente é, todavia não inaugurou, como dizem - de acordo com as notícias sobre os vários falares italianos - a moderna filologia, nascida, ao contrário, do moderno sentimento histórico, não contendo nada de revolucionário nem de relevante para a filosofia da linguagem, mas é de considerar, por outro lado, um documento de formação espiritual da nacionalidade italiana e, sobretudo, da formação artística de Dante, que naquele livro pode e defendeu um ideal de língua e de estilo, o "vulgar ilustre" ${ }^{228}$.

\footnotetext{
126 "uomo d'azione, partecipe a suo modo ala crisi italiana ed europea tra la fine del secolo decimoterzo e il principio del decimquarto" (CROCE, B. La poesia di Dante , p. 9).

${ }^{127}$ Ibid., p. 10.

128 "Notevolissimo come certamente è, tuttavia non inaugura, com'è stato detto, per le notizie che offre sulle varie parlate d'Italia, la moderna filologia, nata invece dal moderno sentimento storico, né contiene nulla di rivoluzionário e nemmeno di relevante per la filosofia del linguaggio, ma è da considerare, da uma parte, documento del formasi spirituale della nazionalità italiana" (CROCE, B. La poesia di Dante, p. 14).
} 
Aqui, mais uma vez, a posição de Pasolini irá de encontro àquela que Croce defende em suas menções à obra dantiana. Enquanto fica claro nos ensaios pasolinianos a influência de Dante para uma ideia de poesia dialetal - através de sua mistura de linguagens como matriz de pensamento do plurilinguismo italiano -Croce desqualifica a interpretação dada por muitos autores acerca da obra do poeta florentino. Desse modo, Pasolini seguia uma tendência mais comum em sua interpretação, ao atribuir a Dante um pioneirismo que já havia sido criticado por Croce anos antes.

Mas, retomado a leitura de Croce, ele propõe em seu ensaio - contra o exagero que é comum a muitas interpretações sobre Dante - uma análise que leve em consideração "uma história da cultura medieval e daquela que o poeta florentino, em particular, se sabia ou se cria em certos personagens e certos mitos (...)"129. Ou seja, Dante tem que ser inserido em um contexto, em uma interpretação mais realista, de modo a relativizar a mitificação que muitos de seus intérpretes fazem de suas obras, sendo fundamental observar, por exemplo, quem são suas referências poéticas, visto que ele não surgiu do nada.

O primeiro capítulo, Croce dedica-se a analisar a trajetória do jovem Dante até a produção de sua obra canônica, a Divina Comédia. As primeiras poesias escritas pelo jovem poeta fazem uso de temas e esquemas muito comuns a outros poetas de seu tempo, principalmente do grupo ao qual ele se aproximou no início de suas atividades, aquele que deu origem ao Dolce Still Nuovo, " uma escola do amor". Esse grupo inspirou-se na poesia provençal, adaptada à realidade da região italiana daquele tempo. Segundo Croce, Dante “ (...) cultivava um ideal que era um refinamento da velha ideologia erótica dos rimadores provençais, e da provincialismo italiano, atuando sobre a escolástica e o sentimentalismo do misticismo cristão e franciscano" ${ }^{130}$. No entanto, apesar de ter se vinculado desde

129 "Una storia della cultura medievale, e di quella di Dante in particolare, importa ricercare che cosa si sapesse o si credesse su certi personaggi e su certi miti"'(Ibid., p. 17-8).

130 "si coltivava si era formato per un afinamento ed elevamento della vecchia ideologia erotica dei rimatori provenzali e dei provenzaleggianti italiani, attuato sotto l'efficacia, per quel che sembra, di concetti della filosofia scolastica e di abiti sentimental del misticismo critiano e franciscano" (Ibid., p. 34). A poesia provençal, na forma como foi redescoberta pelos poetas modernos (como Ezra Pound), foi caracterizada como percursora de Dante. Augusto de Campos a definiu como "crítica de costumes", usando como principal recurso a sátira. Os provençais valorizavam um determinado tipo de realismo, entendido por um forte apelo sensual e humorístico. Outra característica da poesia provençal era sua obscuridade e bizarrice, derivados do seu 
o início a um grupo de poetas mais experientes, tais como Guido Guinizzelli, Dante conseguiu desenvolver um estilo próprio. A leitura croceana atribuiu essa singularidade característica do estilo dantiano ao que era preconizado pelo próprio movimento, já que

Os poetas que seguem o chamado " doce novo estilo", quando não são realmente poetas, não seguem à risca esse estilo, ora fazendo outra coisa do programa, ora respeitando somente no seu exterior e em determinações secundárias. Os próprios alunos, os executores do programa (...) são levados, em vez disso, (...) a dar a seu saber artístico a sua força poética e a maturidade de engenho $(\ldots)^{131}$.

A poesia da Divina Comédia, desse modo, pode ser entendida como resultado da formação e do alinhamento de Dante ao Dolce Still Nuovo, cujas características permitiram a ele desenvolver uma obra que ganhou a dimensão e ser chamada por Bocaccio de "Divina". A excepcionalidade da Comédia, segundo Croce, é atribuída a sua retórica, que se mostra inovadora, espontânea e sincera, fazendo uso não só das palavras, mas também da imaginação, do ritmo, diante de uma forma convencional, e quase musical, sendo a inspiração poética o amor. A leitura de Croce também aponta à predileção de integrantes do "doce estilo novo" pelas canzoni. Elas foram frequentemente utilizadas por Dante em suas composições - tal como ele expressa em seu tratado De Vulgari Eloquentia e também no Convívio - como a forma mais ideal de compor poemas no "vulgar ilustre". Assim, mais um elemento característico da poesia dantesca deve-se ao seu alinhamento ao movimento liderado por Guanizzelli, o que demonstra ser Dante um espírito que, ao mesmo tempo em que criou asas, também possuia raízes.

Nos capítulos subsequentes, a análise de Croce dedica-se a analisar as partes que compõem a Comédia, o que, no entanto, não interessa ao presente trabalho. Desse modo, o texto avança em direção aos dois últimos capítulos, que tratam da unidade da poesia em Dante e da crítica que se construiu acerca sua de

conteúdo sintético, antidiscursivo, que também faz parte de sua crítica de costumes. Sobre isso, ver: CAMPOS, A., Verso, reverso, controverso, p. 10 e 94.

131 "I poeti, che a esse si accostano e credono e s'illudono di seguirle, sempre, quando veramente sono poeti, se ne allontanano nel fato, ora facendo altra cosa sal programma accettato $e$ professato, ora rispettandolo solo nell'esteriore e in determinazioni secondarie. Gli Scolari veri e propri, gli esecutori di programmi, (...) sono portati invece (...) a dare alle loro sapere astistiche (...)” la loro forza poetica e la maturità dell'ingegno" (Ibid., 34). 
suas composições. Os dois últimos capítulos relacionam-se ao que Croce iniciou na parte introdutória da obra, ao apontar como as interpretações feitas sobre o poeta fundaram um mito.

O sexto e penúltimo capítulo começa com uma pergunta: "que coisa é este espírito dantesco, o ethos e o pathos da Comédia, a "tonalidade" que the é própria?”. Logo em seguida, Croce atribui esse espírito ao mundo que Dante fundou em sua obra canônica, “ um mundo fundado em uma firme crença e um seguro juízo, e animado de uma robusta vontade" ${ }^{132}$. Ou seja, Croce é um autor que também se deixou impressionar pelo realismo dantesco, como Auerbach e o próprio Pasolini. A realidade na Comédia é bem construída, e isso se dá pelo fato de o poeta conduzir a narrativa de sua peregrinação rumo ao Paraíso. Somado a isso, Dante também foi capaz de criar um mundo imaginário, fruto de uma "mística cognição", ao abordar elementos intrínsecos a uma interpretação divina $^{133}$.

O último capítulo da obra croceana é, na realidade, um apêndice, que trata justamente da crítica existente acerca da obra de Dante, concluindo algo que Croce havia mencionado na introdução de sua obra. É justamente nessa parte menor e auxiliar do livro que Croce escreverá os parágrafos mais importantes ao pensamento pasoliniano, visto que ali são traçadas as conexões entre o pensamento de Dante, com aquele que fora desenvolvido por Giambattista Vico e pelos os românticos.

Croce atribui a Vico o início de uma "revolução na crítica dantesca", ao elevar a poesia do florentino como digna de comparação com os poemas homéricos - ao se referir a ele como o "Homero da Idade Média". Assim como ocorreu com o poeta grego, Dante acreditou ter formado a própria língua, selecionando-a de todas as línguas de sua nação. Vico, segundo Croce, considerava a Comédia sob três aspectos, “ aquele do estudo literário que extraiu belíssimos falares toscanos; aquele da história porque contém uma história do

132 "che cosa è, dunque, questo spirito dantesco, l'ethos e il pathos della Commedia, la "tonalità" che le è propria?" e "fondato sopra una ferma fede e un sicuro giudizio, e animato da una robusta volontà" (CROCE, op. cit., p. 161).

133 "Mística cognição", de acordo com o que Dante dá a entender no texto, relaciona-se ao "mistério da criação, providência e vontade divina, que se revela somente na visão de Deus" (Ibid., 161-162) ["mistero della creazione, provvidenza e volontà divina, che si svela solo nella visione di Dio”]. Ou seja, a uma sabedoria fundada na Providência Divina. 
tempo bárbaro da Itália; e, mais do que qualquer outro, aquele poético, no qual profere exemplo de sublime poesia"134. Vico teria inovado ao ter como tema central de seu trabalho a exaltação de uma doutrina estética da poesia dantesca, destacando elementos como a fantasia e a intuição. Vico consideraria Dante o verdadeiro símbolo da poesia, pois ela fora resultado da paixão, e não da reflexão.

O Dante poeta - tal como os poetas teólogos que Vico analisou na Ciência Nova - fundou, através de uma sabedoria poética proveniente da imaginação, uma noção de realismo. Croce destacou a importância do legado deixado por Dante, que o fez tornar-se tão valioso a um conjunto de pensadores. Ainda de acordo com Croce, além da extrema inteligência que demonstra em assuntos em torno da natureza poética (como Vico apontou), Dante também se aproximava de uma ideia de poesia vinculada a uma verdade religiosa e moral.

A leitura que Croce fez da crítica viquiana também identificou no poeta florentino um senso poético (tal como consta na Ciência Nova) que era superior a um tipo de poesia sem potência, superficial. Para Croce, Dante enxergava a poesia como semelhante à teologia, envolta "em fábulas as causas das coisas, os efeitos das virtudes" ${ }^{135}$. Desse modo, Croce encontrou no pensamento viquiano semelhanças com a poesia que Dante desenvolveu na Comédia a partir do elemento em comum que existiria em ambos, qual seja, a questão da fantasia.

Quanto ao resgate de Dante na região da Alemanha, Croce aponta que Goethe, como um dos percussores do pré-romantismo, não compreendia como a Comédia podia distrair o leitor, já que, "o Inferno o tornava horrendo, o Purgatório equívoco e o Paraíso chato" ${ }^{136}$. Desse modo, ele apresentou a primeira metade do século XVIII como avessa à poesia dantesca, fato que só teria se modificado a partir da publicação de J. J. Bodmer, de 1763, intitulado Ueber das dreyfache Gedicht des Dante. Segundo a leitura croceana, Bodmer era um pensador dotado de um espírito viquiano, e talvez essa informação seja importante para compreender o fato de ele (Bodmer) ter identificado na poesia do florentino

\footnotetext{
134 "quello dello studio letterario, in quanto vi si attingono bellissimi parlari toscani; quell della storia, perchè contiene una storia dei tempi barbari d'Italia; em maggiore d'ogni altro, quello poetico, nel quale porge esempio di sublime poesia”. Ver: CROCE, B., La poesia di Dante., p. 174.

135 "favole le cagioni delle cose, gli effetti delle virtù" (Ibid.,. p. 176)

136 “ "I'Inferno a lui tornava orrendo, Il Purgatorio, equivoco e il Paradiso noiso" (Ibid., p. 180$181)$.
} 
algo de extraordinário. Nas palavras de Croce, isso significava dizer que a Divina Comédia,

junto com a Ilíada, participava da mesma censura, como contrário aos costumes, à decência, à graciosidade do gosto moderno, desatento às regras à unidade de ação; exceto àquilo, Dante (contrapôs) observou as suas próprias regras, e tinha assim várias coisas para retratar que, para poder fazer uso de cada tipo de estilo, ele parecia muito confortável em adotar a forma de uma fantástica viagem ${ }^{137}$.

Nesse ponto, é possível notar a aproximação entre essa característica da poesia dantesca segundo Croce com elementos pensados por Pasolini. Uma poesia à margem, menos preocupada com regras de composição poética que com a impressão realista de sua poesia, fruto da fantasia. É possível notar como os argumentos de Croce servirão também de argumento para corroborar as ideias de Pasolini quanto à realidade poética.

Ao invés de seguir o pensamento de Goethe e definir a estrutura da Comédia como esquisita, Croce entendeu que Bodmer enxergou a obra como um “invento singular e original". Dante, desse modo, recebeu uma crítica favorável, que o ajudou a ser resgatado no século XVIII. A partir desse momento, o que sua poesia tinha de diferente era justificado por um direito seu de utilizar os caracteres poéticos de seu tempo. Enfim, o poeta florentino começava a ser aceito entre os poetas do Setecentos, e muitos elementos que se encontravam na poesia desenvolvida naquele século, ou seja, a poesia romântica, passou a ser também identificada em seu poema, tais como ser um poema cercado de humana paixão. Assim, até o próprio Goethe - que em 1788 criticava a estrutura da Divina Comédi - reviu sua opinião e, no ano de 1826, passou a afirmar que Dante, como Giotto, “ dominava(...) um gênio sensível, figurativo, onde ele enxergava de modo distinto, com olhos de imaginação, os objetos da maneira que eles poderiam ser" ${ }^{\prime \prime}$.

A crítica do século XVIII e XIX, portanto, contribuiu para alçar Dante, juntamente com Homero, Shakespeare e Cervantes, como os poetas de maior

137 "partecipava com l'Iliade ai medesimi biasimi, come contrario ala costumezza, ala decenza, ala graziosità del gusto moderno, inosservante delle regole e dell'unitá d'azione" (Ibid., 181182).

138 "dominava (...), il gênio sensibile figurativo, onde egli vedeva in modo cosí distinto com l'occhio dell immaginazione gli oggetti da poterli rendere con netti contorni”' (Ibid., p. 183). 
importância à modernidade, e Dante passou a ser considerado como um autor não mais medieval, mas teria inaugurado, portanto, a poesia moderna. Sua capacidade em unir em uma mesma obra ciência, religião, arte, história e uma nova noção de mitologia fez com que a Comédia alcançasse o posto de obra canônica, como " a poesia da poesia". Croce, assim, concluiu seu livro apresentando uma linha interpretativa que fornece um conjunto de informações importantes para se pensar a noção de poesia pasoliniana. Ele conseguiu relacionar a obra de Dante ao século XVIII - período no qual se desenvolvia o Romantismo na Alemanha - por intermédio dos escritos de Giambattista Vico. Pasolini encontra em Croce um argumento sistemático que o tenha ajudado em torno de uma ideia comum de poesia, como consta nos ensaios de Passione e Ideologia ${ }^{139}$.

Um outro ensaio importante escrito por Croce foi dedicado à obra do poeta Giovanni Pascoli, uma das principais referências poéticas de Pasolini. No ensaio intitulado Giovanni Pascoli, studio crítico, escrito em 1907 e publicado como livro em 1920, Croce faz sua análise sobre esse autor, cuja poesia ele considerava esquisita. Logo no princípio, ele tenta justificar-se por esse posicionamento, não admitindo desgostar do que leu sobre a obra do poeta, como se já previsse um possível julgamento de seus leitores: "eu sei que o juízo de arte, embora seja baseado na impressão do ingênuo, não termina nas primeiras impressões" ${ }^{140}$.

Apesar de tecer bons comentários acerca da descrição das paisagens e de personagens, tanto humanos quanto animais, ele desfere seu comentário mais direto ao leitor quando desqualifica o poema I due cugini como obra-prima:

Obra-prima? Nem mesmo aqui. Eu tenho feito referência a versos e estrofes singulares, transformando em uma pequena composição. Mas, se você tivesse lido-o inteiro, teria, provavelmente, dado um conceito muito menor. Deixa estar um longo "bordado" que Pascoli fez sobre os chamados "pés desencapados". "Pés descalços", disse tudo; mas, ao contrário, não há jogo de palavras ${ }^{141}$.

\footnotetext{
${ }^{139}$ Essa sistematização do Croce, na verdade, foi trabalhada também por outros, como Auerbach. O que ele tem em comum? Todos leitores de Hegel que, na Estética, chama a atenção para o realismo da Comédia. A este respeito, ver o capítulo 2 da dissertação de mestrado de Patrícia Reis, intitulado "O mundo terreno vasculhado em seu íntimo ou sobre 'Dante poeta do mundo secular", . Ver: REIS, P., Indivíduo e Destino: o significado do Mundo Histórico no Dante de Auerbach. 140 "So bene che il giudizio dell'arte, benché si fondi sulla ingenua impressione, non si esaurisce nelle considdette prime impressioni” (CROCE, B., Giovanni Pascoli, studio critico, p. 1).

141 " Capolavor? Neppur qui. Io ho riferito versi e strofe singole, trascegliendo nel piccolo componimento. Ma, se ve l'avessi letto intero, ve ne avrei dato forse um concetto assai minore.
} 
E assim Croce prossegue em sua análise da poesia pascoliana, como $\mathrm{Il}$ sogno dela vergine, em La cavala storna, Il giorno dei morti, entre outros. Mesmo em poemas no qual ele enxerga qualidades, há sempre algo que o faz sentir o poema esquisito. Em verdade, a Croce desagradava em Pascoli justo aquilo que muitos autores, incluindo Pasolini, vão tecer elogios: a questão da mistura de estilo e linguagem. Ainda ao pensar na obra Myricae, Croce continua:

nele, depois de Myricae, surgiram diversos motivos poéticos felizes, um pouco mais ricos talvez e mais profundos do que seu primeiro; mas tais motivos não foram padronizados e reduzidos a uma unidade artística e não compraram aquela entonação harmônica que é manifestação de unidade. Era um esquisito poeta em Myricae. (...) Mas a fama o tem alcançado e o tem motivado a uma produção abundante e $\operatorname{artificial}^{142}$.

Nesse ponto de seu ensaio, Croce referia-se especificamente ao que definiu como época pré-histórica pascoliana, em que o poeta trabalhava com a questão da linguagem primitiva, entendendo-a como relacionada à linguagem da infância. A profundidade que muitos autores enxergam nas obras de Pascoli são, para Croce, uma artificialidade e muitas vezes um exagero. Tal fase é marcada pelo uso de onomatopeia, o que é, na perspectiva croceana, um erro grave e repetido diversas vezes, e que leva a uma reprodução excessiva e a uma afetação e disposição assinfônica. Quanto à questão da língua, tão importante nas discussões do presente trabalho, Croce mais uma vez criticou as ideias pascolianas, afirmando que a língua adotada por ele é genérica e cinza. Sobre isso, Croce apontou:

É evidente, para lembrar a doutrina estética, que Pascoli estava equivocado, trocando e confundindo em um ideal de infância, que é próprio da poesia a qual ele se liberta do interesse contingente e se coloca rapidamente na coisa, - a infância que é uma imagem da contemplação pura, - com a realística infância,

Lascio stare il lungo ricamo che il Pascoli fa sul particolare deu piedini nudi.". Piedi nudi", disse tutto; ma il Pascoli, invece, non senza giuoco di parole" (Ibid., p. 5).

142 "In lui,anche dopo Myricae, sono sorti motivi poetici felicissimi, anzi più ricchi forse e più profondi dei suoi primi; ma codesti motivi non vengono padroneggiati e ridotti a unità artistica, $e$ non acquistano quell'intonazione armonica, che è la manifestazione dell'unità. Era uno squisito poeta nelle prime Myricae, restio a scrivere e a stampare, tanto che si denominava da sé " Belacqua», e, sfiducioso, non cercava la fama. Ma! la fama l'ha raggiunto, e lo ha eccitato a uma produzione abbondante e artificiale" (Ibid., p. 57). 
que gira em torno de um pequeno mundo porque não conhece e não é capaz de dominar ${ }^{143}$.

Croce, portanto, possuía uma posição mais conservadora quanto ao trabalho realizado por Giovanni Pascoli, diferentemente da opinião de outros, tais como Contini e o próprio Pasolini, que exaltavam naquele poeta o seu plurilinguismo. Contudo, apesar das divergências de opiniões, não se pode ignorar a importância dos escritos croceanos aos estudos literários no século XX, sendo esse ensaio sobre Pascoli frequentemente citado em trabalhos de crítica literária. Compreender o pensamento de Croce acerca desse poeta consiste em compreender de que modo ele foi apresentado à geração de Pasolini - que em sua juventude foi apresentado à poesia pascoliana - encantando o jovem a ponto de ser escolhido como tema do trabalho de conclusão do curso de graduação, intitulado Antologia della lirica pascoliana (1945).

\subsection{Gianfranco Contini: de Dante a Pascoli}

Contini ocupa uma posição de referência intelectual nos ensaios pasolinianos de Passione e Ideologia tão importante quanto à de Croce. Segundo Nico Naldini, Contini foi, cronologicamente, o segundo "grande homem" da vida poética pasoliniana ${ }^{144}$. Tal como Croce, Contini foi um crítico literário cuja obra pode ser considerada abrangente, tendo ele escrito textos sobre autores clássicos italianos, como Dante, Petrarca, Manzoni, Leopardi, Pascoli, entre outros. O seu rigor e empenho, principalmente em analisar o estilo de cada um dos nomes mencionados, o torna uma referência obrigatória nos ensaios pasolinianos - que, como já foi dito, é repleto de referências quanto a uma ideia de poesia popular. Enquanto a obra croceana de 1929 foi fundamental ao desenvolvimento dos argumentos pasolinianos quanto aos estudos sobre poesia popular italiana, Contini, em sua obra Preliminari sulla lingua del Petrarca (de 1951), discorre sobre um tema que será fundamental à construção dos ensaios de Pasolini: a

143 "Ora è evidente, per quanto riguarda la dottrina estetica, che il Pascoli ha equivocato, scambiando e confondendo in uno l'ideale fanciullezza, che è propria della poesia la qual si libera dagl'interessi contingenti e s'affisa rapita nelle cose, - la fanciullezza che è immagine della contemplazione pura, - con la realistica fanciullezza, che si aggira in un piccolo mondo perchè non conosce e non è in grado di dominarne uno più vasto" (Ibid., 62).

${ }^{144}$ NALDINI, N., Pasolini, biographie, p. 31 
distinção entre a ideia de língua em Dante e em Petrarca. Tal fato pode ser percebido a partir do ensaio de Pasolini Il reame. Nele, o ensaísta apresenta tal texto continiano como fundamental ao desenvolvimento de uma ideia de poesia realista, entendida por ele como resultado de um "terreno experimental" em que

(e nós usamos aqui dois termos de um belíssimo estudo de Gianfranco Contini, Preliminari sulla lingua del Petrarca, in "Paragone", abril, 1951) um cânone monolinguístico, complexo e mediado, de origem petrarquesca, e que veio a compor a corrente mais típica da literatura italiana - cede, em parte, à pressão daquele bilinguismo (...) que é, por definição, uma reação antiacadêmica, e compõe aquela constante menor, mas quanto mais feliz, que se origina da mais realística obra de poética italiana, a Divina Comédia ${ }^{145}$.

Pasolini, portanto, atribuiu a Contini uma relevância fundamental ao seu argumento acerca da formação de dois pólos da poesia italiana, aquela de Dante e a de Petrarca. Evidentemente, Pasolini alinhou-se às perspectivas dantianas, seja de realismo, seja de poesia, visto que elas seriam intimamente vinculadas. Desse modo, o objetivo desse subcapítulo é justamente o de identificar, a partir da interpretação do ensaio continiano, quais foram os argumentos utilizados por Pasolini para defender a existência de uma oposição entre Dante e Petrarca quanto a uma ideia de língua. Assim como as demais referências, Pasolini fez uso das ideias presentes no texto continiano de maneira muito livre. Por exemplo, sua definição de monolinguismo e plurilinguismo ora se afasta ou se aproxima daquilo que Contini expôs. Preliminari sulla língua del Petrarca foi pensado mediante as distinções entre a poesia de Dante e Petrarca por um viés linguístico, enquanto Pasolini confere ao seu ensaio um sentido mais sociológico. A análise que ele realiza no texto confere ao leitor uma sensação de neutralidade diante da poesia de Dante e Petrarca, enquanto no ensaio pasoliniano fica mais nítida a sua predileção pelo estilo dantiano.

Por penetrar em um terreno perigoso, ao analisar um tipo de poesia característica do humanismo, cujo desenvolvimento desembocaria em uma

\footnotetext{
145 “( e ci serviamo que dei termini di um belíssimo studio di Gianfrando Contini, Preliminari sulla lingua del Petrarca, in "Paragone", aprile, 1951) um canone monolinguistico, complesso e mediato, di origine petrarchesca, e venuto a comporre la costante più típica dela letteratura italiana - cede in parte alle pressioni di quel bilinguismo (...) que è per definizione uma reazione anti-accademica, e compone quella constante monori, ma quanto più Felice, forse, che si origina dalla più realística dele opere poetiche italiane, la Divina Comedia" (PASOLINI, P. P., Il reame. In: Passione e Ideologia, p. 12).
} 
infinidade de temas, há em Contini uma preocupação em justificar seu objeto de estudo o que explica o nome do ensaio. Ele sabia da impossibilidade de abarcar em menos de 30 páginas tudo que se relacionasse à linguagem em Petrarca. Assim, ao afunilar o seu objeto, ele “ aproveita-se da circunstância que os linguistas distinguem em um duplo sentido: o da sincronia e o da diacronia" ${ }^{146}$. Na verdade, Contini entende que analisar a língua petrarquiana pelo viés da diacronia seria mais viável. Ele entendia ser a análise diacrônica aquela cujo método faz uso de elementos de oposição ou comparação, no caso Petrarca e Dante. E assim parece ser o caminho pelo qual ele trilhou a sua análise. Ao escolher a diacronia como sua opção de análise, ele define o que pretende especificamente no texto: determinar a consciência histórica em Petrarca. Para Contini,

(...) nós modernos nos sentimos mais solidários com o temperamento, digo o temperamento linguístico, de Dante; mas é, entretanto, um fato que a substância da nossa tradição é mais próxima à cultura petrarquesca. Por outro lado, é longo o tirocínio exercitado pelos modernos sobre a violência verbal, dos românticos ao expressionismo, e deixamos em exagero o novo, segundo aquelas luzes, de aprendizado dantesco $(. . .)^{147}$.

Para Contini, portanto, apesar de a tradição linguística italiana dever muito mais a Petrarca que a Dante, é algo comum dos movimentos culturais analisar a obra de Petrarca em relação à dantesca, o que acabou tornando-se a opção de análise do próprio autor. Quanto à questão da tradição italiana de tipo petrarquiano - definida quase sempre a partir da poética clássica -, defende que o próprio Petrarca limita esse significado mais comumente atribuído a ele. Esse é um ponto que Contini não se prolonga muito, interessando a ele mais a relação do poeta com as tradições mais próximas ao seu período, tal como o Stil Nuovo. Assim, o ensaísta definiu como tradição italiana " aquela própria à iniciativa de Petrarca, e será por definição uma iniciativa linguística de tonalidade média, de excursão modesta"148. A tradição em Petrarca que interessa ao ensaio é a da poesia em língua vulgar, tal como se encontram os poemas em Canzoniere. Já a

\footnotetext{
146 "della sincronia e della diacronia". (CONTINI, G., Preliminari sulla língua del Petrarca. In: Varianti e altra linguística: uma raccolta di saggi, p. 170)

147 “ noi moderni ci sentiamo più solidali col temperamento, temperamento linguistico, di Dante; ma è altrettanto um fatto che la sostanza della mostra tradizione è più prossima all cultura petrarchesca. D'altra parte, il lungo tirocínio esercitato dai moderni sulle violenze verbali, dal romanticismo all'espressionismo, e metticiamoci pure il noviziato, secondo quei lumi, dell apprendimento dantesco" (Ibid., p. 170).

148 "próprio all'iniziativa petrarchesca, e sarà per definizione um 'iniziativa linguistica di tonalità media, di escurzione modesta" (Ibid., p.171).
} 
característica da obra Dante que ele se propôs a analisa, ou seja, aquela que foi colocada em oposição à de Petrarca é a questão do plurilinguismo. Mas isso não se alude

somente ao latim e à língua vulgar, mas à "poliglotia" do estilo e, digamos, do gênero literário (...). E em Dante convivem a epistolografia de tipo apocalíptico, o tratado de tipo escolástico, a prosa vulgar narrativa, a didascalica, a lírica trágica e humilde, a comédia ${ }^{149}$.

O plurilinguismo em Dante seria tanto que, para Contini, o leitor fica carregado de todo o tipo de linguagem. Outro ponto destacado pelo comentador era o experimentalismo dantiano. A estrutura plurilinguista em Dante, cuja principal referência seria a Divina Comédia, é apresentada no texto como resultado de um tipo de interesse teorético, o que já poderia ser verificado em obras como De Vulgari Eloquentia e Convívio. Assim, a percepção continiana sobre a poética dantiana visualiza como centro de referência desse poeta "o infinito". Após a apresentação resumida do que entendia ser a "língua de Dante", Contini pôde, a partir da oposição a Dante, problematizar a "língua de Petrarca'.

A Petrarca também pode ser atribuída alguma influência do movimento Stil Nuovo, o mesmo através do qual surgiu a figura do poeta Dante. No entanto, Petrarca configurou o seu estilo de modo muito mais particular em relação ao movimento do que o estilo dantiano. Em Petrarca, por exemplo, seria percepitível tanto à herança siciliana quanto ao uso de elementos vernaculares em seus poemas. No entanto, ainda segundo Contini, esse poeta eliminou elementos da rima siciliana, instituiu elementos típicos da tradição rigorosa do italiano escrito, e, ao mesmo tempo, estabeleceu um estilo "entre a forma florentina, a de ascendência siciliana ou provençal, ou latina ou todas aquelas coisas juntas" ${ }^{\text {"150. }}$. Desse modo, percebe-se que em Petrarca, havia espaço também para uma mistura de línguas e estilos. Mas, onde residiria, então, o seu monolinguismo?

\footnotetext{
149 "solo a latino e volgare, ma ala poliglotia degli stilli e, diciamo la parola, dei generi letterari (...)Ecco in Dante convivere l'epistolografia di piglio apocalittico, il trattato di tipo scolastico, la prosa volgare narrativa, la didascalica, la lírica trágica e la umile, la comédia” (Ibid., p. 171).

150 “ (....) tra forma florentina e a forma di ascendenza siciliana o provenzale o latina o tutte queste cose insieme" (Ibid., p. 176-177).
} 
Nesse momento, a argumentação de Contini se volta àquilo que ele definiu como o aspecto diacrônico de sua análise, pensando Petrarca em função de Dante, e marcando a oposição entre eles. Portanto, se em Dante o ensaísta visualizou um plurilinguismo carregado tanto para o grotesco quanto ao sublime, em Petrarca ele faz questão de marcar um monolinguismo. No entanto, o que ele identifica como um monolinguismo em Petrarca é somente quanto à unidade de tom e léxico que o poeta faria questão de manter em seus poemas, mesmo misturando estilos de diversas línguas - conforme foi citado anteriormente. Assim, pode-se perceber que a ideia de unidade no ensaio continiano não exclui a mistura de estilos de diversas poesias italianas, mas somente preserva o item lexical de determinada língua, sendo ela vernáculo ou não.

Outro ponto importante da análise de Contini, e que merece ser apresentado, é o da relação entre esses poetas com a língua vernacular. Para Dante, a poesia vulgar deveria ser elevada à dignidade de uma poesia sublime, seguindo a ideia da existência de um "vulgar ilustre", tão digno quanto o latim. Já em Petrarca não havia uma ideia de "vulgar ilustre", como havia em Dante, mas somente o uso de línguas vulgares como um espaço de experiência acerca de estilos poéticos. Em comum entre eles, havia a preocupação em conhecer os diversos estilos de poesia existentes nas regiões de língua italiana.

Desse modo, ao ler o ensaio continiano, sua análise acerca da poesia de Dante e Petrarca se mostra muito mais complexa do que o comentário de Pasolini dá a entender. Ele não define a poesia de Dante como totalmente plurilinguista, tampouco a de Petrarca como monolinguista. O que ele faz é problematizar esses conceitos, mostrando como a poética dos dois é mais complexa do que se pode parecer. A leitura de Contini deixou muito mais suave essa oposição, aproximando a obra petrarquiana à de seu antecessor.

Outro texto de Contini que contribui de maneira interessante a este trabalho foi o escrito para ser apresentado em uma conferência em San Mauro em 1955, intitulado Il linguaggio di Pascoli. Contini analisa obras como Myricae, Canti del Castelvecchio, Il fanciullo, mas preocupado com uma apreciação geral da poética pascoliana. Neste texto, o autor introduz seu argumento nomeando a linguagem utilizada nas poesias de Pascoli como "cislinguistica", definida por ele 
como aquela que exorbita a norma, "ou transcende o modelo de língua que é conhecido da tradição literária, ou fica aquém dela (...)”. Assim, Contini parte para apresentar os primeiros elementos que nessa língua podem ser identificados à onomatopeia, que leva à presença de um "fonosimbolismo", fugindo completamente de uma noção de língua gramatical. A língua de Pascoli é "agramatical ou pré-gramatical", e Contini entende ser ele (Pascoli) o primeiro a fazer uso dela, identificando-a principalmente a partir da onomatopeia, a fim de representar o som da natureza. Além dessa, há no poeta uma preocupação em utilizar também a contração de palavras, transformando-as em som. E é nisso que Pascoli cria uma nova língua ${ }^{151}$.

Outro elemento importante identificado por Contini na poesia de Pascoli é o uso do plurilinguismo, tal como em Dante. Mas a mistura de línguas e estilos parece ao ensaísta menos uma atitude revolucionária que uma atitude tímida do poeta, como uma incapacidade de implodir a tradição. Para Contini, essa mistura empreendida pela poesia pascoliana não consegue fugir de uma opção pela tradição, pois ele,

(...) se exprime em medidas tradicionais, e entre o metro da tradição existe aquilo que Carducci chamava de bárbara, aquela cujo metro imitava a fabricação do verso greco-latino: metro que (...) contribuiu "de maneira reformada" ao advento do verso livre. Mas há uma diferença capital entre o verso bárbaro carducciano e o verso, dizemos agora, bárbaro, pascoliano (aquele que ele chamava neoclássico) $(\ldots)^{152}$.

No entanto, a posição de Pascoli parece oscilante em relação a essa tradição, ao menos pela interpretação continiana. Ao mesmo tempo em que se mantinha próximo, Pascoli também procurava se afastar da tradição poética e para Contini, o poeta só "não se tornou revolucionário porque não quis". E completa:

Com isto não entendo significar que não havia vontade em sua consciência psicológica, mas ele representava obviamente um tipo de autor mal resolvido entre os limites de um gênero, mas perenemente exorbitante de outro, embora isso representasse uma heresia. (...). Em resumo, não há em Pascoli nenhum

\footnotetext{
${ }^{151}$ CONTINI, G., Il linguaggio di Pascoli [Acesso em meio eletrônico].

152 "Si esprime in misure tradizional, e fra i metri dela tradizione vi è ormai anche la tradizione che Carducci chiamava barbara, quella cioè dei metri che imitato la fabbricazione del verso greco-latino: metri che, (...) contribuiscono "riformisticamente" all'avvento del verso libero. Ma c'è una differenza capitale trai l verso barbaro carducciano e il verso, diciamolo ancora bárbaro, pascoliano (che però Pascoli chiamava neoclássico)" (Ibid.).
} 
gênero, nenhuma instituição revolucionária, nenhuma tradição atual ou virtual em estado puro ${ }^{153}$.

A posição indefinida de Pascoli diante da tradição e o seu plurilinguismo o afastavam de ser identificado com qualquer movimento literário de seu tempo, como também de qualquer no estilo literário clássico. No entanto, Contini conseguia identificar nesse aspecto, uma semelhança entre Pascoli e os poetas do século XIX francês, como Rimbaud, Mallarmé e Verlaine. Em comum entre eles existe aquilo que no ensaio é definido como uma poesia fragmentária, que não se aproxima nem se afasta completamente da tradição, e cujo papel nos versos é o de funcionar como freio de uma absoluta liberdade de tom. Essa posição contraditória de Pascoli não o torna o suficientemente revolucionário e talvez seja essa impossibilidade de relacioná-lo à tradição que torne sua poesia tão esquisita aos olhos de alguns críticos, tais como Benedetto Croce.

A Pasolini, no entanto, a poesia pascoliana não soava tão esquisita, mas inspiradora. E nesse aspecto Contini já enxergava o mérito da poesia pasoliniana para o desenvolvimento da atividade poética no século XIX. Ao final de seu texto, ele menciona justamente a inspiração de Pasolini no estilo de Pascoli, apontando como principal referência disso a Academia de lengua friulana, fundada por

um animado poeta, romanesco de resto, mas que começou sua a escrever em friulano, Pier Paolo Pasolini, e da jovem escola que ele conseguiu promover e reunir-se em torno. Se você avaliar no conjunto os resultados deste singular felibrismo friulano, não há dúvida que ele caracteriza o próprio gosto da obra, com temas ainda que modernos, em matéria verbal que como tal seja inédita: um similar experimento seria difícil negar uma qualidade pascoliana ${ }^{154}$.

\subsection{Entre o mono e o plurilinguismo: a análise de Pasolini acerca da tradição poética italiana}

\footnotetext{
153 "Con questo non intendo significare che non l'abbia voluto nella sua coscienza psicologica, ma che egli rappresenta obbiettivamente il tipo di um autore non rinchiuso entro i confini di un genere bensì perenemente exorbitante da ogni genere, anche se questo genere fosse l'eresia (...) . Insomma non c ${ }^{\prime e ̀ ~ i n ~ P a s c o l i ~ n e s s u m ~ g e n e r e, ~ n e s s u m ~ i s t i t u t o ~ l e t t e r a r i o, ~ n e s s u n a ~ t r a d i z i o n e ~ a t t u a l e ~ o ~}$ virtuale allo stato puro" (Ibid.).

154 “(...) un, animoso poeta, romagnolo del resto, ma che há cominciato a scrivere in friulano, Pier Paolo Pasolini e dalla giovanne scuola che riusci a promuovere e riunirsi attorno. Se si valutano nel loro insieme i produtti di questo singolare félibrige friulano, è indubbio che li caraterizzi proprio il gusto di operare, con termi anche modernissimi, in uma matéria verbale che come tale sia inedita: a um simile esperimento sarebbe difficile negarei l predicato di pascoliano" (Ibid.).
} 
A partir de uma leitura da obra de Gianfranco Contini (Preliminari sulla lingua de Petrarca) Pasolini definiu duas matrizes poéticas que deram origem às modernas concepções de poesia na Itália: a noção de poesia monolinguista de Petrarca, colocada em oposição àquela que teria em Dante seu percursor, a poesia dita plurilinguista. Tal plurilinguismo também permitiu que Pasolini aproximasse o fazer poético dantiano daquele desenvolvido pelo poeta do século XIX, Giovanni Pascoli, cujas poesias eram entendidas como uma "mistura de linguagens". Assim, entende-se aqui que a interpretação que Pasolini deu à obra continiana o levou a determinar suas próprias definições acerca do uso das línguas em Dante e em Petrarca, ultrapassando os limites impostos por Contini em seu texto. Desse modo, o objetivo desse subcapítulo é justamente o de analisar quais são essas novas interpretações, entendendo-as como ponto de partida para uma tomada de posição do próprio Pasolini em sua filiação a um tipo de fazer poético compreendido por ele como iniciado em Dante e seguido por Giovanni Pascoli.

Acerca da interpretação de Pasolini sobre Dante e Petrarca, serão analisados três ensaios: Il reame, que consta em Passione e Ideologia, A vontade de ser poeta de Dante (1964), tradução disponível em Empirismo Hereje e In ocasione del sesto centenário dela morte de Petrarca (1975), que consta em Saggi sulla letteratura e sull'arte. A opção por utilizar outros ensaios além daqueles compilados em Passione e Ideologia se deu pela necessidade de melhor desenvolver os argumentos e problematizar a leitura que Pasolini faz dos dois poetas. Contudo, o cerne da leitura de Pasolini se manteve em todos eles: Dante e Petrarca como referências de fazeres poéticos distintos. No que tange ao fazer poético em Pasolini, essa distinção será importante para marcar a aproximação do que se definiu como realismo dantesco.

No ensaio Il reame, de 1955, Dante e Petrarca são apontados como as duas principais referências poéticas italianas a partir da interpretação pasoliniana acerca do texto de Contini. A menção feita ao texto continiano se resume à apresentação de Petrarca como cânone monolinguista - e como aquele que influenciou uma tradição academicista italiana - enquanto Dante seria o principal representante da poesia plurilinguista italiana, cuja referência maior seria a obra canônica a Divina Comédia, definida por Pasolini como “ a mais realística obra 
poética italiana" ${ }^{155}$. O modo como os ensaios de Passione e Ideologia foram estruturados privilegiou o maior desenvolvimento de alguns temas, em detrimento de outros - como é o caso da leitura do ensaio continiano - o que contribuiu para incutir no leitor a ideia de que em Preliminari sulla lingua de Petrarca, Contini definiria a poética em Dante como oposta à de Petrarca. Fica claro o equívoco dessa ideia a partir da leitura do ensaio de Contini e de outros textos pasolinianos que tratam do mesmo assunto.

A fim de problematizar a temática, não se atendo ao ensaio dos anos 50 , vale a pena recorrer ao ensaio de Pasolini de 1965 intitulado A vontade de ser poeta em Dante. Nele, Pasolini expressa melhor o que entendia ser o "plurilinguismo" dantiano, a partir daquilo que leu em Contini:

(...) com Dante, a vontade de empregar na Commedia a língua da burguesia comunal florentina, nasceu também a vontade de compreender as diversas sublinguagens de que essa língua era formada: gírias, linguagens especializadas, particularismos de elite, contribuições e citações de línguas estrangeiras, etc. O alargamento linguístico de Dante, devido ao deslocamento de seu ponto de vista para cima (...) não é apenas um alargamento do horizonte lexical e expressivo: mas, ao mesmo tempo, também social ${ }^{156}$.

Pasolini vai analisar a poesia dantesca em seu aspecto sociológico. A perspectiva adotada nesse ensaio é muito importante aos argumentos pasolinianos em defesa não somente da língua, mas também de uma realidade dialetal/camponesa. Pasolini divisava em Dante algo muito parecido com aquilo que ele próprio tencionava realizar: usar a língua como principal elemento de inserção nas discussões políticas de seu tempo. O ensaísta bolonhês atribuiu esse interesse de Dante para a vida política a uma "consciência ligada à organização corporativa no quadro da comuna de florentina",

e a vontade de empregar as diversas sublínguas da língua vulgar, da sua participação directa e activa arquétipa nas complexas lutas políticos-sociais da sua cidade. Dante não se encontrava mergulhado num mundo monolítico como o que, durante toda a Idade Média, foi o do universalismo teológico-clerical (leia-se italiano), que nivelava tudo, etc. (...) o mundo projetado em Dante pelo seu próprio mundo social particular fosse um mundo analítico, dividido segundo as diversas características sócio-políticas, e portanto linguísticas, contraditórias (situação que até hoje se repete na sociedade italiana) ${ }^{157}$.

\footnotetext{
${ }^{155}$ PASOLINI, P. P., Il reame. In: Passione e Ideologia, p. 12.

${ }^{156}$ Id., A vontade de ser poeta em Dante. In: Empirismo Hereje, p. 81

${ }^{157}$ Ibid., p. 82 e 83.
} 
A situação linguística ao final da Idade Média era identificada por Pasolini como semelhante à de seu tempo, tornando possível a ele pensar seu fazer poético a partir do que identificava na obra do poeta napolitano. Nesse ponto da análise vale a pena fazer uma observação quanto a um poema pasoliniano, intitulado $L a$ Divina Mimesis, cuja estrutura do poema faz referência à organização da Divina Comédia, o que fica claro pelo próprio título. O Inferno na obra de Pasolini é aquele da poesia burguesa neo-capitalismo, pós anos 60, enquanto o Purgatório foi identificado como aquele período de "morte da ideologia", que data dos anos 60 e, por fim, o Paraíso, que é entendido por Pasolini como aquele período anterior aos anos 50, pensando ele na poesia dialetal (em especial a friulana) anterior à influência da cultura burguesa. Enquanto o personagem de Dante ruma em sentido ao Paraíso, guiado pelos poetas clássicos, a sociedade da época pasoliniana percorria o caminho contrário, em direção ao Inferno (cultural).

De volta à análise do ensaio de Pasolini dos anos 60, ele desenvolve seu texto também mediado pela leitura que Contini realizou em Preliminari sulla lingua del Petrarca, o qual, segundo ele, teria influenciado todos estudos sobre o tema a partir dos anos 50. O grande mérito da interpretação continiana seria, segundo a leitura de Pasolini, o de apresentar a sociedade do tempo de Dante como

(...) uma sociedade que exigia impetuosamente, a quem nela vivesse, uma "consciência social”, e sem a qual a extensão plurilinguística não seria mais do que meramente numérica, ou talvez meramente expressiva: um maravilhoso êxtase linguístico, que contemplava todas as palavras faladas na sua funcionalidade e na sua beleza $(. . .)^{158}$.

A leitura que Pasolini fez do ensaio continiano teria encaminhado sua visão acerca da estética de Dante por dois pontos de vista: um que apresenta ao leitor uma interpretação transcendente, universal - ligada ao espírito religioso da época (pensamento tomista) - ou aquele que analisa o mundo por um ângulo mais detido nas "vielas comunais e das ravinas dos Apeninos", ou seja, uma interpretação mais particular da realidade, caso a caso. Desse modo, Pasolini não

\footnotetext{
${ }^{158}$ Ibid., p. 83.
} 
consegue definir se seria Dante o “inventor de uma 'Língua Vulgar Universal', ou alguém que inaugurava a 'Língua Vulgar como langue florentina, como todas as sublinguagens históricas' ${ }^{\prime 159}$. Apesar de ser possível identificar em Dante esses dois registros interpretativos, o particular e o universal, o uso dos vernáculos encontrava-se presente em ambos, e era este o aspecto mais importante da obra dantiana.

De acordo com Pasolini, o uso dos vernáculos na obra de Dante confundese não somente com uma realidade, mas com uma posição crítica diante dela, e o resultado disso fez surgir a poesia plurilinguísta. Nesse sentido, a obra do poeta florentino é definida por Pasolini como "garantia de inspiração ideológica, de escrita concebida no interior de toda a vontade poética directa", entendida no ensaio como inspiradora de toda uma "poesia marginal", que aqui pode ser entendida como a poesia não acadêmica, como aquela que o próprio Pasolini entendia fazer.

Aquilo que Pasolini vislumbrava na poesia de Dante era a sua capacidade de romper com a hierarquia entre as línguas, valorizando a multiplicidade de uso das mesmas. Com isso, é possível perceber na leitura que o ensaísta fez da poética de Dante - principalmente na Divina Comédia - uma semelhança com o que ele próprio entendia como o verdadeiro sentido da poesia: uma linguagem usada na vida, referente não aos padrões rígidos de uma ideia hermética de poesia, mas derivada da experiência, tal como em Pasolini ao entrar em contato com a realidade da cultura friulana, o que lhe "deu o gosto de vida e do realismo". Nesse sentido, a noção que Pasolini possuía de realismo assemelha-se àquela que ele pode identificar em Dante.

No entanto, ao final de seu texto, Pasolini parece retroceder ao entender que a poesia de Dante na Divina Comédia não era tão radical assim - não tão radical à época pasoliniana, mas certamente à Idade Média - pois não haveria nela uma aproximação entre os dois tipos de linguagens do cotidiano, embora

\footnotetext{
${ }^{159}$ Nota do tradutor da obra Miguel Serras Pereira, quanto à ideia de langue em Pasolini: "Pasolini parece querer vincar ao máximo uma alusão à distinção saussuriana entre langue e parole, que, de resto está presente ao longo de quase todas as páginas destes seus ensaios [ que fazem parte do livro Empirismo Hereje], ao mesmo tempo que, sem dúvidas, estes problematizam muito agudamente a tradição pós-saussuriana" (Ibid., p. 83).
} 
extremas: a culta e a "afectivo-familiar-plebeia". Ele conclui seu ensaio entendendo não haver em Dante uma "mistura de linguagens" em uma mesma frase, por exemplo; na obra dantiana cada linguagem se encontra sempre em seu lugar, separada uma da outra, mesmo se encontrando num mesmo poema. A aproximação entre o culto e o baixo na Divina Comédia existe, segundo Pasolini, tão somente na cabeça do seu leitor. O plurilinguismo no poeta florentino, entende ele, era tão somente vinculado a uma "visão realista da sociedade", à sua tomada de posição quanto às questões sociolinguísticas de seu tempo. No que tange à construção do poema,

A contraposição do plurilinguismo de Dante ao monolinguismo de Petrarca era, pelo menos para a "pequena companhia" (...) errada, ou parcialmente errada. Quando muito poderia opor-se um monolinguismo a outro monolinguismo: um monolinguismo escolhido e seletivo ( o de Petrarca) e um monolinguismo tonal (Dante); um monolinguismo devido à interacção infinita da própria atitude interior e da própria relação com uma realidade cristalizada ( Petrarca) e um monolinguismo devido a uma equidistância perfeitamente inalterável ante a própria atitude interior e a própria relação com a realidade; um monolinguismo como solilóquio eternamente homogêneo (Petrarca) e um monolinguismo que homologa incessantemente as mais diversas ficções de diálogo (Dante) ${ }^{160}$.

O grande ponto em que a poesia de Dante e Petrarca se parecem e são, por isso, consideradas monolinguisticas é a valorização de um estilo elevado. A "mistura de línguas" em Dante, mesmo que mais aberta à linguagem "plebeia", faz um uso selecionado dessa, prevalecendo em sua poesia o "vulgar ilustre", cuja defesa ele já realizava desde os seus primeiros anos no Dolce Stil Nuovo, e que foi detalhadamente definida em De Vulgari Eloquentia. Pasolini identificou que o plurilinguismo em Dante era, portanto, seletivo, visto que o poeta tinha o cuidado de escolher quais e como entrariam as palavras mais simples em seu poema.

Teria, desse modo, Pasolini modificado sua posição quanto ao que havia afirmado no seu ensaio dos anos 50 e, consequentemente, quanto ao que Contini discorre em seu ensaio? Em verdade, o que ocorreu entre o Il reame e este ensaio de 1965 não foi uma mudança radical de interpretação quanto à poética dantiana, mas somente uma tomada de posição menos categórica em relação à existência de duas matrizes poéticas, completamente opostas, na Itália. O que pode explicar essa mudança de perspectiva é justamente a diferença entre o tipo de análise 
realizada por ele em Il reame, e a que ele fez nos anos 60, no ensaio que foi totalmente dedicado a Dante. No primeiro ensaio, ele simplesmente citou uma afirmação dada por Contini em seu ensaio de alguns anos antes, não havendo ali uma preocupação em problematizar as questões que poderiam ter surgido como resultado do texto de Contini. Pasolini, em Il reame, aceitou uma leitura típica do ensaio continiano, e se limitou a definir e distinguir Dante e Petrarca como poetas pluri e momolinguista, respectivamente. O mesmo não ocorre com o outro ensaio, no qual esses temas são melhor abordados.

Mesmo assim, o aspecto plurilinguista não foi excluido na interpretação que Pasolini faz acerca da poesia de Dante na Divina Comédia. O uso de múltiplos léxicos e da linguagem culta e plebeia em um mesmo poema fazem de Dante ainda um poeta racionalista, que apresenta uma visão realista da sociedade, e que o tornam, ainda, um plurilinguista. A diferença está na relativização que deve ser feita dessa definição. Nem mesmo Contini afirmou em seu ensaio que Dante o era completamente. O que aconteceu a partir da apresentação da obra continiana na Itália, foi que essa definição da poesia dantesca se tornou a única possível entre alguns estudiosos da poesia Italiana medieval. Nesse sentido, Pasolini continuou vendo em Contini uma importante referência a análise comparativa entre Dante e Petrarca, mantendo, ainda, a possibilidade de identificar em Dante alguns elementos plurilinguistas.

Em outro ensaio, datado dos anos 70, Pasolini volta a usar o termo plurilinguista, em uma nova comparação da poética em Dante com aquela desenvolvida por Petrarca. Ao escrever por ocasião do sexto centenário de Petrarca, ele estruturou seu artigo em cima das diferenças entre a poesia de Dante e a de Petrarca a partir da questão do léxico. Assim, para ele,

O petrarquismo que teria informado toda a sucessiva literatura italiana por séculos, é na prática o monolinguismo no qual consiste; e que se contrapõe ao plurilinguismo danttiano. (Tal fórmula, de importância decisiva, deve-se a Gianfranco Contini.). E o que isto significa? O Petrarca havia adotado uma língua exclusivamente literária, e as poucas palavras escolhidas de um "jargão poético"161.

161 "Il petrarchismo che há informato di sé tutta la successiva letteratura italiana per secoli, è in prática im monolinguismo in cui esso consiste; e che si contrappone al plurilinguismo dantesco. (Tale formula, di importanza decisiva, è dovuta a Gianfranco Contini). Cosa significa questo? Il Petrarca há adoperado uma língua exclusivamente letteraria, le poche e scelte tparole di um 
Como se referiu somente ao léxico, Pasolini mantem a mesma posição que adotou no ensaio de 1955, quando não exclui, mas relativizou o plurilinguismo dantesco, seguindo um pensamento parecido com aquele que Contini defende em seu texto. Por outro lado, a sua posição acerca da obra de Petrarca não sofreu nenhuma alteração. Foi Dante quem se aproximou de Petrarca, e não o contrário. Mesmo Contini apontando uma "mistura de línguagens" em Petrarca, que mesclava estilos de diferentes níveis e línguas, tendo também composto poemas em língua vulgar, não há em Pasolini um interesse em explorar tal característica da poesia petrarquesca. Na leitura de Pasolini, Petrarca manteve-se, desde o primeiro ensaio (Il reame) como representante de uma tradição acadêmica que até fazia uso da língua vulgar, mas ignorava a linguagem do cotidiano, tornando o italiano uma língua "estrita e exclusivamente literária". Pasolini atribuiu a Petrarca a fundação da tradição literária italiana, que praticamente consiste no uso de uma língua de "elite culta", vinculada a um estilo sublime, que influenciou não somente a língua italiana que se formava a partir daquela época, mas, num sentido sociológico, na forma de vida na Itália nos séculos precedentes.

Desse modo, como já havia sido apontado antes, percebe-se em Pasolini um interesse em descrever o fazer poético de Dante como semelhante ao seu. Enquanto a Petrarca coube o papel da poesia acadêmica, desvinculada da realidade, a poesia que Dante desenvolveu na Divina Comédia, seria, na época medieval, a mais próxima de uma experiência poética realista, pautada na vida do próprio poeta. Da mesma forma como Pasolini procurava problematizar através da linguagem questões relevantes a sua época -tal como a tensão entre o mundo campesino e o burguês - encontrava em Dante uma preocupação em discutir temas que eram importantes durante a Idade Média, como a religião, e o reflexo dessa poesia composta de maneira crítica, reflete-se na originalidade linguística que se encontra na estrutura do poema. Para Pasolini, a realidade era estreitamente relacionada à linguagem.

Foram interesses semelhantes que levaram Pasolini a admirar a poética de Giovanni Pascoli, que, tal como em Dante, era entendida por ele como 
plurilinguista. Assim, pode-se pensar que para Pasolini existe uma continuidade da poesia dantiana no fazer poético de Pascoli, vendo neste um realismo experimental, definido em Passione e Ideologia como um "experimentalismo antitradicional". Ou seja, tal como Dante, Pascoli se dedicou a mesclar elementos linguísticos em sua poesia, fato que tornou suas composições esquisitas a alguns e brilhantes a outros, como Pasolini.

A relação de Pasolini com a poesia de Giovanni Pascoli, como já foi mencionado, teve início em sua juventude. Aos sete anos de idade, o jovem Pasolini já havia iniciado contato com as primeiras poesias italianas, sendo Pascoli um dos primeiros autores que ele leu na sua vida. A admiração que o jovem Pasolini cultivou pela poesia pascoliana resultou na escolha do poeta para ser o tema de seu trabalho de conclusão do curso de graduação em Letras, intitulado Antologia della lirica pascoliana, apresentada em 1945. No trabalho, o jovem universitário afirmava sentir "uma fraternidade humana" pelo poeta, cujo estilo identificava como precursor de seu "experimentalismo linguístico"162.

Desse modo, assim como havia em Pasolini certa identificação com o trabalho de Dante quanto ao aspecto plurilinguista - mesmo que ele tenha concluído ser o plurilinguismo dantiano limitado - também havia pela poética pascoliana, e talvez Pascoli tenha inspirado muito mais o fazer poético pasoliniano que Dante. $\mathrm{O}$ experimentalismo vinculado a esse plurilinguismo era o elemento de aproximação entre os dois poetas, o que permite pensar na influência de Dante no trabalho de Pascoli e desse na concepção poética de Pasolini.

Após o trabalho final de graduação, Pascoli inspirou outros trabalhos de Pasolini, e aquele poeta teve uma influência muito grande nos ensaios coligidos em Passione e Ideologia. No entanto, antes desses ensaios, existe um anterior, cuja primeira publicação data de 1946, no periódico Libertà, intitulado Pascoli e Montale. O tema principal do ensaio era comparar a poesia pascoliana com a do também poeta Eugenio Montale, sendo que Pasolini sustentava a influência da poesia do primeiro nas composições montalianas. Desse modo, apesar do tema, o ensaio é muito importante pela perspectiva que Pasolini oferece ao seu leitor. A análise que o jovem ensaísta faz das composições pascolianas é apaixonada, e o

162 BALDACCI, L., Pasolini e Pascoli, poesia in forma di láurea [Acesso em meio eletrônico]. 
enfoque principal do texto é pensar tais composições como resultado de "uma prosa através de um senso místico do som, de uma fantasia e de uma onomatopeia". A descrição que o ensaio apresenta é bem menos crítica do que aquela que será apresentada nos ensaios de Passione e Ideologia, por exemplo.

Logo nas primeiras páginas do ensaio, Pasolini mostra uma interessante perspectiva para se pensar o estilo pascoliano: ele vincula o misticismo do poeta a uma forma de expressão da realidade. De acordo com o texto, a particularidade da natureza é um jogo poético ou "um jogo da fantasia (...) ou um aroma poético das coisas(...), que orienta o poeta na direção em que ele deve olhar" ${ }^{163}$. Ou seja, mesmo fazendo uma poesia que, segundo Pasolini, era de caráter íntimo, Pascoli conseguiu estabelecer um vínculo com a realidade. Desde o início do ensaio já é possível associar sua poesia àquela noção já apresentada por Vico em defesa da poesia como a forma dos primeiros homens interpretarem o mundo. A poesia pascoliana também era proveniente do contato com a natureza e produtora de uma realidade construída através do sentimento, e não da reflexão.

Outro mérito de Pascoli foi o se afastar das tradições poéticas clássicas e românticas. Segundo Pasolini, o estilo de sua poesia possuía a capacidade de "ignorar aquela dificuldade do infinito que os clássicos e os românticos haviam enfrentado de perto" além de uma

(...) incapacidade de dicção em primeira pessoa diante dos temas universais (o Eu, a morte ...), vem (re) pronunciada por inteiro, sem alusão, encontra, enfim, a própria origem em algo maravilhoso, posteriormente, e depois consciente, concedido, de frente ao objeto e aos mínimos fatos do mundo ${ }^{164}$.

Dessa forma, a poesia pascoliana foi definida por Pasolini como uma "obra menor", não sendo essa uma característica negativa; ao contrário, a noção de "poesia minori" tal como aparece descrita no ensaio é "menor por reduzir a proporção do mundo a um objeto, a uma ocasião no qual o mundo permanece em

163 "un gioco della fantasia (...) l'effluvio poetico delle cose (...) che offròno al poeta per se stessi il modo di voltarei l binocolo" (PASOLINI, P. P., Pascoli e Montale. In: Il pórtico della morte, p. 6).

164 “(...) l'incapacità ad una dizione in prima persona dove i nomi universali (io, morte ...) vengono ripronunciati per intero, senza allusioni, ritrovi infine la propria origine in una meraviglia, a posteriori, e quindi conciente, scontata, di fronye algi oggetti e ai minimi fatti del mondo" (Ibid., p.8). 
síntese" 165 . Entre aquilo que Pasolini considera como "poesias menores" estão as composições dos poetas dialetais e, se são nomeadas "menores", pode-se concluir que o são justamente porque fogem dos grandes temas de tipo universal.

Assim, nesse primeiro ensaio dedicado ao poeta, percebe-se que a Pasolini o interesse maior era analisar a lírica pascoliana, atendo-se a pensar no estilo e no modo como poeta produziu uma ideia de realidade a partir de um texto muito pessoal e de caráter intimista. Portanto, no ano de publicação de seu ensaio, Pasolini colocou-se, invariavelmente, contrário às concepções mais comuns acerca da obra pascoliana - como o texto de Benedetto Croce, já citado, e a publicação da revista literária La Ronda, (1919) ${ }^{166}$. Nos anos 50 foi o também já citado ensaio de Gianfranco Contini (1955), que apresenta uma perspectiva bem diferente da pasoliniana. No mesmo ano em que a Contini produziu seu texto, Pasolini escreveu um novo ensaio, intitulado Pascoli (de 1955), compilado em Passione e Ideologia.

Pasolini escreveu seu novo ensaio por ocasião no centenário de Pascoli, e é possível perceber uma mudança na perspectiva que ele adotou diante do estilo pascoliano. Seu novo olhar, mais crítico, aproximava-se daquele que Contini adotou em seu texto, o que, no entanto, não torna possível afirmar se o ensaio continiano influenciou o de Pasolini (ou vice-versa). A principal suposição é a de que a semelhança de perspectiva adotada pelos autores seja o resultado do período pelo qual passava a Europa com o fim da Segunda Guerra, e, especificamente, a Itália com a queda do regime fascista e a abertura do país à cultura e à indústria estrangeira. O principal efeito dessas transformações para a cultura do país,

\footnotetext{
165 "in quanto riducono le proporzioni del mondo a um oggetto, a un'occasione, in cui quel mondo resta riassunto" (Ibid., p. 8).

${ }^{166}$ La Ronda foi uma revista literária italiana publicada em Roma entre os anos de 1919 e 1923. A principal característica da publicação era o de defender um retorno a uma tradição clássica literária. Os fundadores da revista defendiam " o ideal de uma moderna literatura italiana (...) enquanto fundada sob a tradição, e espelhada no exemplo daquela prosa conjuntamente poética e reflexiva (...)" ("l'ideale di uma moderna letteratura italiana (...) in quanto fondata sulla tradizione, e um mirable esempio di quella prosa insieme poetica e riflessiva (...)". Ver: [http://www.treccani.it/enciclopedia/la-ronda/.]).

Por sua posição favorável a uma produção literária mais tradicional, esta revista considerava esquisito o estilo pascoliano, tal como Croce havia feito alguns anos antes. No entanto, a opinião dos fundadores da revista não era homogênea quanto à poética de Pascoli: Cechi e Cardelli, importantes escritores italianos enxergam naquele poeta "conhecimento dos mecanismos linguísticos", bem como "sua preparação" linguística. Ver: PENNA, M.D., Giuseppe Ungaretti: appunti di viaggio. Theorèin. Disponível em: http://www.theorein.it/letteratura/letita/ungaretti/capitolo\%204.html.
} 
segundo o próprio Pasolini, foi o desenvolvimento de uma cultura de massa, marcada pela mudança de vocabulário e que representava uma nova ameaça à cultura dialetal. Diante disso, Pasolini vislumbrou que era necessária uma tomada de posição muito maior dos intelectuais, pois a "ameaça" à cultura popular não era somente italiana, mas também estrangeira. Nessa conjuntura, a poesia pascoliana passou a ser considerada pelo ensaísta como de um caráter dúbio, entre a inovação e a tradição, entre o experimentalismo e a imobilidade estilística. Essa duplicidade inerente ao fazer poético pascoliano é o mote central do ensaio.

Inicialmente, o que importa a Pasolini é destacar a individualidade do poeta. Para ele, a poesia pascoliana foi produzida "fora do campo de uma moral bellestristica, típica do século XX, todavia se dizia certamente 'literária', de formação e aspiração filológica"167. No entanto, mais do que os critérios da crítica de "laboratório" - como o de pensar se a poesia pascoliana era ou não literária -, importava na obra pascoliana a "sua íntima força paradigmática, sugestiva e de tendência" ${ }^{168}$. Logo no início de seu texto, Pasolini parece ainda se colocar na posição de defender a poesia e o estilo do poeta. Essa atitude não é em vão: Pascoli, já havia sido alvo de inúmeras críticas por seu "experimentalismo". Pasolini defende que críticas como estas correspondem a um primeiro momento de crítica, que já havia sido concluída, e que, após alguns anos de desinteresse dos críticos pela obra de Pascoli, seu ensaio iria retomar os estudos.

Para Pasolini o erro da revista La Ronda, por exemplo, foi justamente fugir do principal na poesia pascoliana: seu "sistema e estético e ideológico", e são esses os aspectos que ele buscou analisar em seu ensaio. O primeiro passo de sua análise procurou mostrar de que maneira a personalidade poética de Pascoli se formou. No entanto, diferentemente do texto de 1946, a psicologia pascoliana nesse novo ensaio foi pensada levando-se em consideração as principais influências à sua formação intelectual. Assim, afirma ele logo no início do texto:

\footnotetext{
167 " fuori dal campo d'uma morale belletristica típica del Novecento, tuttavia si dicono senz'altro "letterati”, di formazione e di aspirazione filológica". PASOLINI, P.P., Pascoli. In: Passione e Ideologia, p. 267)

168 e "sua intima forza paradigmática, soggestiva e di tendenza" (Ibid., p. 267). De acordo com Pasolini, os critérios da crítica literária do século XX levava em conta o esquema, "muito vulgarizado" que definia a poesia como "monolinguista" ou "plurilinguista", da forma como Gianfranco Contini havia, por exemplo, problematizado a poesia em Petrarca e Dante, em seu ensaio de 1951.
} 
Visto quase para si mesmo pelo excesso de intimismo que a sua personalidade poética comporta, ou visto em relação a uma história estilística complexa e geral (colocamos o Romantismo e o Decadentismo europeu, da Wordsworth, a Poe, a Baudelaire), foi negligenciado, até agora, Pascoli de seu ambiente cultural mais imediato e específico: o ambiente cultural, isto é, no qual ele foi formado e operava, e que de resto ele foi muito menos provincial e em certo sentido muito menos europeu do que a posição marginal e retardatária de um Pascoli, relativo, precisamente, ao pós-romantismo europeu, possa fazer pensar ${ }^{169}$.

O problema, segundo Pasolini, era o de se pensar que, na Itália, os poetas de uma geração inspiravam-se necessariamente nos poetas da geração anterior. Havia naquele país, no entanto, uma tendência à involução, como resultado de uma formação histórica que deu origem a uma nação forjada e instituída por uma classe dirigente. Diferentemente do que ocorria na França, marcada pela Revolução Francesa, não havia na sociedade italiana um evento revolucionário que pudesse inspirar seus poetas, como também estimular a consciência da população. A inspiração ideológica dos poetas em direção a uma experiência democrática era, segundo o ensaio, "simplesmente um reflexo francês". A formação e a inspiração intelectual de Pascoli começou nesse momento. Faltou a ele um exemplo contemporâneo na Itália que servisse de inspiração para escrever sobre a poesia de seu país. Sua geração, desse modo, gozou de uma liberdade de pesquisa erudita, marcada pelos muitos exemplos, principalmente franceses, que podiam ser encontrados pela Europa. O resultado disso foi o excesso de pesquisa encontrada em Pascoli, responsável pelo excesso de informações e tendências ${ }^{170}$.

Resumidamente, Pasolini (re)definiu o estilo de Pascoli de acordo com seu temperamento e o seu tempo:

Colocando melhor Pascoli em seu tempo (...) estudando o mais analiticamente possível sua relação com seu período (...), nos encontraremos diante desta primeira formulação teórica a propósito da sua história psicológica e estilística: em Pascoli coexistem, com aparente contradição de termos, uma "obsessão",

169 "Visto quase a sè per l'eccesso di intimismo che la sua personalità poetica comporta, oppure visto in relazione a una storia stilistica complessa e generale (mettiamo il romanticismo e il decadentismo europeo, da Wordsworth, a Poe, a Baudelaire), si è trascurato finora di circostanziare esaurientemente il Pascoli in un ambiente culturale più imediato e specifico: l'ambiente culturale, cioè, in cui egli si era formato e operavaa, e che del resto, era forse molto meno provinciale $e$ in certo senso molto più europeo di quanto la posizione marginale $e$ ritardataria di un Pascoli rispetto, appunto, al post-romanticismo europeo, possa far pensare" (Ibid., 268).

${ }^{170}$ Ibid., p. 269 
tendência patológica a manter-se sempre idêntico a si mesmo, imóvel, monótono e frequentemente doentio, e um "experimentalismo" que, quase compensa aquele controle psicológico, e tende a variá-lo e renová-lo incessantemente. Em outros termos, coexistem nele (...) uma força irracional que o constrange à imutabilidade estilística e uma força intencional que o abre a uma tendência estilística mais díspar ${ }^{171}$.

Ou seja, a possibilidade de seguir por caminhos longínquos e variáveis não fizeram Pascoli se desgarrar de também seguir por uma trilha reta e conhecida. Ele tornou-se ao mesmo tempo um poeta inovador e repetitivo. Ainda pensando no estilo de Pascoli pelo viés psicológico, Pasolini conclui que nesse poeta existiam dois lados: o simpático, derivado de seu experimentalismo e da sua paixão de pesquisador e o outro, antipático, causa da sua imobilidade e uniformidade como poeta. Em seguida, o ensaísta encerra o esquema analítico que privilegiava o viés psicológico, partindo para uma leitura mais detida do fazer poético pascoliano. A principal característica em Pascoli era a sua capacidade de introduzir a língua falada em seus poemas (o que Pasolini definiu como sendo sua Koinè), e era esse um predicado inerente à sua poesia. Tal relação com a língua instrumental tornava a poesia pascoliana rica “ de léxico vernacular (...) configurando-se metricamente em uma lânguida terceira rima de ambiente paisano e campestre, conhecida diante do esquema da poesia média dialetal da primeira metade do século XX (...)" ${ }^{172}$. Nesse ensaio, Pasolini valorizou mais a relação de Pasolini com a poesia dialetal, algo que havia sido brevemente mencionado no trabalho anterior.

No novo ensaio, Pasolini também valorizou a influência pascoliana a inúmeros poetas do século XX, entre estes, Giuseppe Ungaretti - que fez uso de muitas expressões pascolianas retiradas, principalmente, de Myricae. Ele reafirma a influência do poeta no estilo de Eugenio Montale, cuja apropriação de um

\footnotetext{
171 “Aperto dunque meglio il Pascoli sul suo tempo (...), studiando il più analiticamente possible $i$ suoi rapporti con esso, co troveremo (...) di fronte a questa prima formulazione teórica a proposito della sua storia psicológico-stilistica: nel Pascoli coesitono, com aparente contraddizione di termini, uma ossessione, tendente patologicamente a mantenerlo sempre idêntico a se stesso, immobile, monótono e spesso stucchevole, e uno sperimentalismo che, quase a compenso di quella hipoteca psicologica, tende a variarlo e a rinnovarlo incessantemente. In altri termini coesistono in lui (...) una forza irrazionale che lo costringe ala fissità stilistica e uma forza intenzionale che lo porta alle tendenze stilistiche più disparate" (Ibid., 270).

172 "arricchisce (...) di léssico vernacolare (...) configurandosi metricamente in uma po'cascante terza rima d'ambiente paisano e campestre, ci troviamo di fronte allo schema della poesia media dialettale del primo Novecento (...)" (Ibid., p. 271).
} 
vocabulário elaborado por Pascoli e de seu procedimento estilístico (segundo Pasolini foi marcada por "senso cômico, de um mal cósmico, iluminado, de um humilde objeto"), assim como o "tom estupidamente evocativo"173. Desse modo, o estilo esquisito de inconstante de Pascoli foi capaz de inspirar não somente a poesia de Pasolini, mas também de poetas ligados desde a poesia hermética até os poetas dialetais italianos (como o poeta friulano Lorenzoni). Aliás, quanto ao poema Fanciullino (que foi desqualificado por Croce em seu texto), Pasolini define-o como "prefigurado estilisticamente todo a um hermetismo", mesmo estando incluso nele certos elementos dialetais. Nesse ponto, é importante salientar que a Pasolini era possível compor poemas considerados herméticos fazendo uso de dialetos que, para ele eram "o cúmulo do hermetismo", ou seja, uma poesia de difícil entendimento. Com isso, a poesia de Pascoli poderia ser considerada hermética, mesmo estando nela elementos da linguagem dialetal.

A pluralidade do estilo pascoliano, para Pasolini, resultou não somente em um estilo de fazer poesia considerado esquisito ou mesmo confuso. O mais importante ao ensaísta é que toda aquela complexidade aparente da poesia de Pascoli foi determinante para a atividade poética na Itália do século XX, visto que "a língua poética deste século é toda saída da sua, mesmo que por contraditória e destorcida elaboração". E completa:

e aquilo que conta é que tal influência se apresenta exercitada não nos poetas extravagantes, retardatária ou marginal (...), mas propriamente, como dizem os textos, em poetas que se colocam no filão central da poesia do século XX: naquela "História da Palavra" - como definiram os críticos mais qualificados e comprometidos - que indubitavelmente se apresentam na poesia do século XX (...) como o momento mais autêntico e necessário ${ }^{174}$.

A principal característica herdada pelos poetas do século XX (período em que muitos críticos, por sua vez, também se colocaram contra sua poesia) foi uma "obscessão psicológica" que compunha a sua personalidade e o fez dedicar sua vida inteiramente "à função poética". Para Pasolini essa era uma posição

\footnotetext{
173 Ibid., p. 271.

174 "E aquilo que conta é che tale influenza si presenti esercitata non sui poeti extravaganti., ritardatari o marginali (...) ma proprio, come dicono i testi, sui poeti che si collocano nel filone centrale della poesia del Novecento: su quella "Storia della Parola" - come la definiscono $i$ critici più qualificati e compromessi - che indubbiamente si presenta della poesia novecentesca (...) come il momento più autentico e necessário" (Ibid., 272).
} 
semelhante com aquele que os poetas do século $\mathrm{XX}$ estabeleceram com suas atividades de compor poemas, e que o ensaísta exemplificou através de um texto do poeta italiano Alessandro Manzoni: “(...) se percebe uma estima preponderante pela poesia mesma e os poetas, como eles são, não lhes faltam quase nunca falar sobre eles como homens sobre-humanos (...). Ao mesmo tempo falavam como desprezo sobre quase tudo (...)". Pasolini informou ainda a opinião de Antônio Gramsci quanto à profissionalização da atividade poética durante aquele século. De acordo com a citação presente no ensaio, Gramsci defende que "os intelectuais concebem a literatura como uma profissão para eles mesmos, que deve render também quando não se produz nada imediatamente e deve dar direito a uma pensão" 175 .

Esse fenômeno ao longo do século XX foi entendido por Pasolini como reflexo da atuação burguesa nas atividades intelectuais italianas, e que fez surgir uma elite intelectual

cuja história estilística é uma história do indivíduo protegido na invenção de uma koinè que é voltada à literatura, de uma parte, e de outra a uma condição social preservadora do eu na sua paixão estética, a cultivar ou a abominação de tipo religioso ou íntimo, ou o ódio clássico e esquisito ${ }^{176}$.

Desse modo, conclui Pasolini, o plurilinguismo pascoliano pode ser entendido como intimamente vinculado ao seu "experimentalismo antitradicional" - que levou o poeta a misturar diversos estilos linguísticos - e permitia defini-lo como "de tipo revolucionário", porém somente em seu sentido linguístico. Como afirmou o próprio Pasolini, "a figura humana e literária de Pascoli resulta, por conseguinte, uma variante moderna, ou burguesa no senso moderno, de arquétipo italiano, com incompleta consciência da própria força inovadora" ${ }^{177}$. Com isso

\footnotetext{
175 “(...) si vede predominare uma stima preponderante per la poesia stessa e dei poeti quali essi siano, non mancando il poeta quase mai di parlare di sè come di um uomo sovrumano (...) Nello stesso tempo si parla com disprezzo quase di ogni altra cosa (...)" MANZONI, A., apud. PASOLINI, P. P., op. cit., p. 273); Gli intelletuali concepiscono la letteratura come una professione a sè, che dovrebbe rendere anche quando non si produce nulla imediatamente e dovrebbe dar diritto a uma pensione" (GRAMSCI, Antonio. apud. Ibid., 273).

176 "La cui storia stilistica è uma storia d'individui protetti, nell'inventio, da uma koinè già "per lettaratura", da uma parte, e dall'altra da una condizione sociale preservante l'io nella sua passione estetica a coltivare o le abnormità di tipo religioso o intimistico o l'otium classicheggianti e squisito". (Ibid., p. 273).

177 "la figura umana e letteraria del Pascoli risulta dunque soltanto uma variante moderna, o borghese nel senso moderno, dell'archetipo italiano, com incompleta coscienza della própria forza comunque innovativa" (Ibid., p. 274).
} 
Pasolini queria se referir a um certo alienamento de Pascoli diante da importância do seu fazer poético para a história intelectual italiana.

Apesar disso, era Pascoli, entre os intelectuais de seu tempo, um dos poucos que poderia ser considerado como minimamente engajado em questões políticas. De fato, aquilo que Pasolini apresenta acerca dos últimos anos do século XIX, bem como dos primeiros anos do século seguinte (ou seja, o período de atividade pascoliana), é uma Itália marcada pelo enfraquecimento da força expressiva dos intelectuais italianos diante da ascensão de uma burguesia cada vez mais reacionária no poder, sendo o auge desse fenômeno os anos do governo fascista de Benito Mussolini. Nessa conjuntura, a influência de Pascoli se perpetuou durantes muitas décadas do século XX, diante de um cenário intelectual marcado pelo fortalecimento de uma burguesia intelectual ligada aos interesses fascistas. Diante desse cenário, Pasolini entende que grande parte dos literatos desse período pode ser definida dentro de certo "apoliticismo". Essa foi a definição à qual chegou Pasolini, seguindo uma tendência da crítica literária italiana, tal qual o comentário de Antonio Gramsci citado por Pasolini:

(...) tem próprio prejuízo o apoliticismo íntimo, envernizado de retórica nacional detalhada. Deste ponto de vista são mais simpáticos Enrico Conrradini e Pascoli, com seu nacionalismo confessado e militante, enquanto cuidavam de resolver o dualismo literário tradicional entre povo e nação, embora tivessem caído em outras formas de retórica e de oratória ${ }^{178}$.

No entanto, o ponto mais interessante do ensaio pasoliniano é justamente o final, em que ele expôs suas conclusões acerca da poesia em Pascoli após investigá-la à luz da história da literatura italiana contemporânea. Nesse ponto, suas reflexões claramente se afastam daquilo que ele defendeu não só no seu primeiro ensaio dos anos 40 - no qual Pascoli era analisado em função do estilo de Montale -, mas também de tudo aquilo que o poeta representou à sua formação acadêmica. O "experimentalismo antitradicional" e o plurilinguismo pascoliano, que aproximavam esse poeta de um fazer poético dantiano e, por isso mesmo, antipetrarquiano, eram inovações somente de caráter quantitativo, e não

\footnotetext{
178 “ (...) tem proprio nociuto l'apoliticismo intimo, verniciato di retorica nazionale verbosa. Da questo punto di vista sono stati più simpatici Enrico Corradini e il Pascoli, col loro nazionalismo confessato e militante, in quanto cercarono di risolvere il dualismo letterario tradizionale tra popolo e nazione, sebbene siano cadutti in altre forme di retorica e di oratoria" (GRAMSCI, A., apud. Ibid., p. 274).
} 
qualitativo. Isso significava, nas palavras de Pasolini, que a poética pascoliana, em síntese, poderia ser descrita como

(...) um realismo de origem ideológica, a uma visão de mundo supostamente em um ponto de vista trazido de fora do mundo e a partir do qual o mundo resulta maior e em conjunto unificado na sua imensa complexidade (no caso uma complexidade linguística). Em Pascoli, aquele alargamento linguístico é sempre em função da vida íntima e poética do Eu e, posteriormente, da língua literária, em seu momento central e ainda tradicional ${ }^{179}$.

Aquilo que no ensaio dos anos 40 parecia representar para Pasolini um dos méritos da poesia de Pascoli, ou seja, o caráter íntimo de sua poesia, no ensaio posterior, escrito alguns anos depois, já se encontrava impregnado de uma nova perspectiva. Como informado antes, o período em que os ensaios de Passione e Ideologia foram produzidos (entre o final dos anos 40 e final dos anos 50) coincidem com uma época de profundas transformações na Itália, tanto num sentido político quanto social. Por isso mesmo, aquilo que Pasolini entendia como sendo o papel de um intelectual, principalmente de um poeta que era considerado próximo da cultura dialetal, como Pascoli, era uma parcialidade, necessária à defesa da causa popular/ dialetal. A visão de mundo limitada, bem como a indecisão do autor entre o plurilinguismo e uma poesia tradição, desqualificam o sentido social da poesia pascoliana. Nesse sentido, ela seria menos "apolítica" para Pasolini do que o é na interpretação de Gramsci.

Assim sendo, o que ainda restava daquele antigo fazer poético na poesia pascoliana? $\mathrm{O}$ aspecto plurilinguista em Pascoli resultava naquilo que era por Pasolini definido como um "experimentalismo antitradicional", sendo esse o mérito de sua poesia e aquilo que a tornava interessante a Pasolini. A indecisão do poeta em se afastar da tradição e se tornar totalmente revolucionário foi algo que faltou a sua poesia - segundo a opinião de críticos posteriores, como Contini e o próprio Pasolini -, mas isso não desmerecia suas qualidades enquanto poeta, tampouco sua trajetória como homem de militância, mesmo que esta não se refletisse diretamente em seus poemas. A indecisão de Pascoli quanto à tradição

179 “(...) um realismo di origine ideológica, a uma visione del mondo presupponente um punto di vista portato fuori dal mondo e da cui quindi il mondo risulta ingrandito e insieme unificato nella sua imensa complessità (nella fattispecie complessità linguística). Nel Pascoli quell 'allargamento linguístico è sempre in funzione della vita intima e poetica dell'io, e, quindi, della lingua letteraria, nel suo momento centralistico e in definitiva ancora tradizionale” (Ibid., 275). 
não se difere muito do dilema enfrentado pelo próprio Pasolini entre seguir uma postura intelectual totalmente revolucionária, em favor de uma causa, e se afastar completamente de uma tradição poética e intelectual da qual faz parte sua formação. É importante lembrar que, segundo informa um de seus biógrafos, Nico Naldini, havia em Pasolini em suas primeiras poesias, um o reflexo de uma atitude introspectiva, tal como Pascoli, fato que se pode perceber a partir daquilo que informa o próprio Pasolini:

As origens de minha poesia, que é o único sentido de minhas jornadas absurdas e muito ordenadas, são muito profundas, mas ela só foi interrompida depois de um bom tempo (...). Eu havia entrado em um mundo selvagem, sem qualquer fórmula; eu estava no interior de mim mesmo, em uma solidão atroz, desumana, e de mais a mais eu me tranquei no meu deserto $(. . .)^{180}$.

Como Pascoli, Pasolini iniciou sua produção poética a partir de uma postura introspectiva, mesmo que após alguns anos ela se tenha aberto ao mundo, principalmente à realidade campesina, dialetal. E mesmo dentro dessa realidade, a poesia ainda emanava de sua inspiração, decorrente de sua relação com a natureza, tal como seu antecessor. Outra semelhança entre esses dois poetas, era a relação com a cultura dialetal e a cultura burguesa. Não se pode negar, e nem o próprio artista o fazia, o pertencimento de Pasolini à classe burguesa, e de como esse pertencimento tornava sua visão do mundo dialetal distinta de um camponês natural daquele mundo, por exemplo. O que talvez possa ser considerado um elemento diferenciador entre ambos é que a atividade política de Pasolini estava mais refletida em seu fazer de literato do que se poderia perceber em Pascoli.

Por fim, a crítica de Pasolini ao estilo de Pascoli é muito semelhante àquela que anos depois, em seu ensaio dos anos 60, fará sobre a poética em Dante, conforme já foi discutido nesse subcapítulo. Tanto em um quanto no outro, segundo Pasolini, faltava uma atitude mais revolucionária quanto ao estilo poético, o que não diminui a importância deles para a história da poesia italiana,

180 "Les origines de ma poésie, qui est le seul sens mês journées absurdes et três ordonnées, sont três profondes, mais ele s'em est coupée depuis um bout de temps(...) Je suis entre dans um monde sauvage, sans plus aucune formule; je suis, à l'intérieur de moi-même, dans une solitude atroce, inhumaine, et de plus em plus je m'enferme dans ce désert (...)" (NALDINI, N. Pasolini, biographie, p. 98). 
tampouco significa dizer que eles não eram, para a crítica pasoliniana, revolucionários. Cada um deles, no entanto, foi revolucionário para seu tempo, mesmo que, segundo o ensaísta, pudessem ter sido mais.

Por outro lado, Pasolini valoriza aquilo que cada um fez de inovador para a época que viveram, demonstrando assim a força da poesia como linguagem não somente no âmbito artístico ou intelectual, mas também como forma de expressão social. Com isso, torna-se possível afirmar que o intuito de Pasolini - a partir daquilo que ele pôde absorver tanto da poesia de Dante, como também de Pascoli (sendo esses os poetas que mais influenciaram a sua formação) - era estabelecer uma nova noção de poesia plurilinguista, que fosse revolucionária a seu tempo, entendendo por isso, uma poesia mais próxima daquilo que ele considerava realista: a poesia dialetal. 


\section{Pasolini ensaísta}

Os ensaios constituíram uma forma muito comum de Pasolini se expressar, principalmente em textos destinados à publicação nos periódicos italianos. Assim como a poesia foi a principal linguagem de sua juventude, os ensaios tornaram-se um importante modo de expressão desse autor conforme foi se tornando mais consciente nele a vontade - que ele defendeu como uma missão de vida - de atuar em defesa da preservação da cultura popular/dialetal italiana. A participação de Pasolini nas discussões políticas se intensifica a partir dos anos 40, através de seus textos de crítica em forma de ensaio, que discorriam sobre temas diversos, mas que possuem em comum o fato de serem uma tentativa de o autor em questionar um modelo cultural em desenvolvimento na Itália. Inicialmente, seu principal objeto de estudo era a poesia popular italiana, que ele identificou na Itália como sendo a poesia dialetal. Em seguida, ele ampliou sua abordagem para pensar na questão linguística italiana em seu uso corriqueiro, nos falares cotidianos e de como essa linguagem sofreu um processo de mutação ao longo dos anos.

Desse modo, o objeto de análise deste capítulo são, principalmente, os ensaios escritos por Pasolini entre o final dos anos 50 até os anos 70. Nesses textos, o escritor encontrava-se em uma nova fase de suas discussões sobre linguagem, ampliando os seus argumentos a assuntos que demonstram claramente a sua opinião quanto à relação da linguagem com as questões políticas na Itália. Os temas relativos ao estudo sobre a poesia na Itália passaram a dividir as atenções com as discussões sobre a transformação linguística que o país atravessa desde a sua unificação, e que se intensificaram com o fim do regime fascista e a abertura das fronteiras italianas à economia e à cultura estrangeira - mais precisamente ao longo dos anos 50. A partir dessa época, o inimigo pasoliniano não era somente a língua forjada pela burguesia italiana (que fazia sucumbir a dialetal), mas sim dois novos entraves à manutenção dos dialetos nacionais: primeiramente, os hábitos e vocabulário estrangeiro, que eram divulgados dentro da Itália pela televisão somados, em seguida, à língua burguesa, fazendo o país mergulhar num processo de massificação da cultura, ou seja, a imposição de 
comportamentos a partir da lógica industrial, estimulados pela publicidade e a televisão.

O objetivo de ampliar a análise desse capítulo a um mapeamento da atividade ensaística pasoliniana reside no interesse em verificar de que maneira seus ensaios posteriores a Passione e Ideologia carregam em seus argumentos aquilo que Pasolini já defendia ao longo de seus ensaios sobre crítica poética, ou seja, como a relação do autor com os dialetos o levou a se tornar um crítico da cultura que se construía na Itália de seu tempo. Como um capítulo não seria o suficiente à análise de toda a obra ensaística pasoliniana, optou-se por se concentrar nos ensaios em que Pasolini teve como interlocutor outro importante intelectual de seu tempo, Italo Calvino. A variedade de temas debatidos por ele ao longo dos anos 50 e 60 deixou um material muito interessante a ser estudado. Desse modo, inicialmente, vamos apresentar resumidamente a trajetória de Pasolini dentro da atividade ensaística.

\subsection{A obra ensaística pasoliniana}

Antes de analisar a atividade ensaística de Pasolini, cabe frisar que sua atuação como crítico deve ser pensada como anterior aos ensaios, já que, segundo ele, sua atividade intelectual sempre foi crítica. Em ensaio escrito à revista Illustrazione Italiana em 1962, ele afirma:

É verdade que meu primeiro livro, publicado em 1942, foi um livro de poesia. E é verdade também que comecei a escrever poesia aos sete anos, no segundo ano do primeiro grau (...) mas sabe-se lá por que, quando penso, indistintamente, no começo da minha carreira literária, vejo como alguém proveniente de crítica $(\ldots)^{181}$.

O livro em questão é o Poesia a Casarsa (1942), que reúne escritos poéticos que ele produziu em sua juventude e foi publicado quando o autor tinha apenas 20 anos. Quanto à afirmação de que sua poesia era proveniente de crítica, ele a fez levando em conta a sua relação com a cultura dialetal, sobretudo o friulano. O primeiro contato de Pasolini com este dialeto, e, a partir dele, a cultura

${ }^{181}$ PASOLINI, P. P., Il Portico dela morte, apud. AMOROSO, M. B., A paixão pelo real: Pasolini e a crítica literária, p.15. 
dialetal como um todo, permitiu-lhe observar uma realidade, um modo de interagir e interpretar o mundo que diferia daquela realidade urbana - da qual o próprio Pasolini fazia parte - em que o ritmo acelerado e as urgências do cotidiano conferiam outra perspectiva de vida e relação com o espaço e tempo. O choque de mundos, o interesse de Pasolini por aquele novo mundo, tão diferente do seu, inspirou-o a escrever seus primeiros poemas. Conforme foi apresentado na introdução dessa dissertação, o próprio poeta afirmou anos depois o que o levara a estabelecer uma relação tão íntima com a vida campesina/dialetal: o gosto de vida e de realismo que aquele ambiente proporcionava a ele.

Desse modo, foi um caminho natural ao jovem poeta escrever seus primeiros ensaios justamente sobre aquela realidade, aliando a poesia à cultura dialetal, dando origem aos ensaios que foram compilados posteriormente em Passione $e$ Ideologia (1960). Na realidade, esse livro possuía ligação com obras anteriores de Pasolini. A introdução do livro Poesia dialettale del Novecento (1952), e a introdução de Canzoniere Italiano (1955) foram modificadas e reeditadas, dando origem à primeira parte do livro. Já a segunda parte, dedicada ao poeta Giovanni Pascoli, reúne textos escritos por Pasolini para a inauguração da revista literária Officina (1955).

Enquanto pensava poesia, Pasolini ampliava seus horizontes em direção a outras questões relativas à linguagem na Itália. Esses ensaios, escritos a partir do final dos anos 50 até os últimos anos de sua vida (nos anos 70), foram compilados em livros posteriores aos de sua fase poética, tais como Empirismo Eretico (1972), Scritti Corsari (1975), Lettere Luterane (1976), Descrizioni di descrizioni (1979), Saggi sulla letteratura e sull'arte e Saggi sulla politica e sull'arte (ambos publicados em 1999), entre outros. Como se percebe, grande parte dos livros ensaísticos do autor foram publicados postumamente. Isso é importante para apontar para o fato de que a discussão dos ensaios pasolinianos ter sido feita a partir da leitura desses nos muitos periódicos em que ele escrevia, principalmente em revistas literárias, onde atuava como colaborador ou até mesmo revisor.

Pasolini fundou junto com outros jovens pensadores de sua época algumas revistas literárias. Entre essas pode-se citar, Il Setaccio (1942-43), Il Stroligut (fundada em 1945, logo após a fundação da Academia de Lengua Friulana) e 
Officina (1955-58). Entre os periódicos que ele atuou apenas como colaborador, há o semanal Tempo (1939- 76), o jornal de grande circulação Corriere della Sera (1876- até hoje), a revista Vie nuovi (1946-78), em ele respondia às cartas dos seus leitores, a revista ligada ao PCI, Rinascità (1944- 91) e a Illustrazione Italiana (1873-1962). A variedade de jornais em que possuía espaço para publicar seus textos mostra como as ideias pasolinianas provocavam algum tipo de interesse entre seus contemporâneos, e o espaço aberto para que respondesse aos seus leitores também demonstra como seus ensaios eram lidos, gerando discussões.

Pasolini fez dos periódicos italianos um meio pelo qual pôde ampliar suas discussões inerentes às questões linguísticas de sua época, algo que dificilmente conseguiria escrevendo poemas. A forma de ensaio, escolhida por ele para publicar seus textos, também é aqui pensada como intencional. Os ensaios, por serem mais curtos, eram mais fáceis de serem lidos, tornando acessíveis a um número maior de leitores. Esse tipo de texto tornou-se o principal meio de expressão do autor ao grande público a partir dos anos 60 por meio dos periódicos; eram nos ensaios que Pasolini expressava-se de maneira mais direta sobre os assuntos inerentes à sociedade de seu tempo. Não será forçoso dizer que ele, desse modo, contribuiu de maneira ativa aos debates relativos à cultura italiana de seu tempo.

A seguir, serão analisados mais especificamente os ensaios em que ele dialoga com outro importante pensador de seu tempo: Italo Calvino. A partir dessa querela, é possível compreender alguns dos temas que envolviam as discussões na qual Pasolini estava inserido, sendo Calvino um dos muitos interlocutores que teve durante esse período.

\subsection{A querela entre Pasolini e Italo Calvino}

Italo Calvino e Pier Paolo Pasolini foram contemporâneos na Itália em um período de efervescência de novos temas, como literatura e política. Parte de uma geração que nasceu entre duas Guerras Mundiais, e vivenciou a experiência fascista (bem como a Guerra Fria), esses dois pensadores possuem uma trajetória muito semelhante. Ambos se dedicaram às letras, tiveram uma experiência no 
Partido Comunista Italiano, e se tornaram, cada um a seu modo, referência de intelectuais italianos até hoje. Existiam, todavia, pontos fortes de discordância entre eles, o que contribuiu para o surgimento de algumas controvérsias. Temas ligados à cultura italiana, como a questão das fábulas, a relação entre a industrialização e a cultura italiana e, principalmente, sobre o papel da linguagem em uma sociedade que vivenciava uma intensa modificação nos seus modos e costumes, levaram esses dois autores a desenvolverem uma querela. Enquanto Calvino identificava as transformações vivenciadas pela sociedade italiana principalmente a partir da década de 50 - como positivas, Pasolini as entendia como causas do desaparecimento das tradições e culturas típicas da Itália, e que foram definidas por ele como uma "mutação antropológica". Em torno do posicionamento assumido por eles, alguns assuntos tornaram-se debates, e permearam a imprensa italiana entre o final dos anos 50 e 60.

Existia uma tentativa da burguesia em forjar uma língua nacional através da literatura. Tal língua foi definida por Pasolini como "italiano médio". Ele referia-se a ela dessa forma justamente por ser o resultado de uma iniciativa da classe média burguesa. O problema apontado por ele é que tal projeto linguístico resultou em algo que não refletia a realidade daquela sociedade. $\mathrm{O}$ empenho de integrar linguisticamente a Itália recém unificada, no entanto, não foi tão fácil e o país se viu dividido em duas linguagens, a falada e a escrita (literária). Quanto a esse assunto, Pasolini, por exemplo, se expressou no ensaio Novas Questões Linguísticas:

$\mathrm{Na}$ Itália não existe uma língua nacional verdadeira e própria. Assim, se quisermos buscar uma unidade qualquer entre as duas personalidades da dualidade (língua falada- língua literária), devemos buscá-la no interior do indivíduo histórico usuário ao mesmo tempo dessas duas línguas, individuo este uno e historicamente descritível em uma totalidade unitária de experiências ${ }^{182}$.

Para Pasolini, a dificuldade em romper com essa dualidade linguística, unificando a linguagem falada e a literária, residia no fato de a língua formada pela burguesia não se relacionar com a realidade da população italiana, já que ela era imposta verticalmente, não sendo o reflexo de suas experiências. A língua,

182 PASOLINI, P. P., Novas Questões Linguísticas. In: Diálogos com Pasolini. Escritos 19571984, p. 18. 
assim, refletiria um corpo histórico-social específico, e produziria uma realidade fragmentada, de "sua luta de classe". A língua, portanto, estava atrelada à realidade burguesa, formando uma koiné. Assim, o problema que envolvia esse projeto linguístico era o de não levar em consideração as especificidades naturais pré-existentes na sociedade italiana, como a distinção entre os dialetos, que variavam de acordo com cada região do país. A tendência desse período foi o desaparecimento das línguas dialetais, que primeiramente deram espaço ao italiano (de tipo dantiano), e que sofriam com a interferência dessa nova língua burguesa que se construía.

Com isso a Itália se via dividida em diversos tipos de línguas, para as quais Pasolini estabeleceu uma distinção: a língua "média", ou seja, tipicamente burguesa e que era parte daquele projeto de unidade linguística, a "inferior, dialetal", ligada à população campesina e a língua que ele denominou "superior, hermética", vinculada a um tipo de produção poética e às Academias italianas. A língua dialetal acabava sendo suprimida pela maioria dos pensadores, e desconsiderada. Pasolini identifica Calvino como um escrito hermético, que para ele significava um distanciamento da literatura popular, ligada à língua dialetal. $\mathrm{O}$ Hermetismo, que para ele fazia uso de uma língua de "difícil entendimento", era como ele entendia a linguagem usada pelos poetas ligados às Academias italianas, por exemplo.

No entanto, qual seria o posicionamento de Italo Calvino acerca dessas questões? Até que ponto ele e seu interlocutor Pasolini se encontravam em lados opostos? A fim de compreender melhor a relação que Calvino estabeleceu com a cultura dialetal, vale a pena observar o que ele expôs na introdução ao livro Fábulas italianas quanto ao desafio de reunir e traduzir as fábulas dialetais italianas:

Para mim era - e disso me apercebia muito bem - um salto no escuro, como pular de um trampolim e mergulhar num mar em que há um século e meio só se atreve a entrar quem é atraído não pelo prazer de nadar entre ondas insólitas, mas por um apelo do sangue, como para salvar algo que se agita lá no fundo e que, caso contrário, se perderia sem voltar à tona (...).

(...) Eu mergulhava nesse mundo submarino desprovido de qualquer arpão especializado, desamparado, sem óculos doutrinários, sem carregar nem mesmo aquela bomba de oxigênio que é o entusiasmo por tudo que seja espontâneo e 
primitivo, por qualquer revelação daquilo que - com uma expressão gramsciana bem cunhada - se chama hoje de "mundo subalterno" 183 .

\subsubsection{As fábulas italianas}

A produção de Fábulas italianas foi um dos pontos de divergência entre os dois autores. A obra, publicada pela primeira vez em 1956 pela editora Einaudi surgiu, como justificou seu autor, "de uma exigência editorial: pretendia-se publicar, ao lado dos grandes livros de contos estrangeiros, uma antologia italiana" 184 . O trabalho de pesquisa arquivística e a tradução dos dialetos foi feita como uma encomenda da editora Einaudi, motivada pela ideia de criar uma antologia do folclore italiano, tal como existiam no caso inglês (dos irmãos Grimm). Assim, diferentemente de Pasolini, Calvino não possuía uma relação pessoal com a cultura popular dialetal. O primeiro contato com essa foi distante e profissional. Com o tempo, porém, Calvino descobriu a riqueza que a envolvia e

(...) ia descobrindo que esse fundo fabular popular italiano é de uma riqueza, limpidez, variedade (...). Assim, quanto mais afundava em minha imersão, mais diminuía o distanciamento da controlado com que mergulhara, e me sentia admirado e feliz com a viagem e o frenesi catalogatório $(. . .)^{185}$.

Ao longo do trabalho, portanto, Calvino foi se aproximando de uma visão acerca da cultural dialetal muito semelhante àquela que Pasolini quando ainda era adolescente. No entanto, mesmo tomado por encantamento, a atividade de etnólogo de Calvino ainda se distanciava de seu contemporâneo quanto ao método. O contato dele com essa cultura consistiu em pesquisar as fábulas em cima do trabalho de recolhimento dos folcloristas, e, a partir dessa catalogação inicial, selecionar entre as muitas versões das mesmas narrativas as mais originais ou bonitas e traduzi-las ao italiano literário. Mas, por que não buscar pessoalmente uma versão para essas narrativas, verificando suas permanências e mudanças - como parte da cultura oral de uma determinada região e dialeto? A justificativa para isso Calvino oferece ao leitor após descrever seu método:

Trabalhei em material já reunido, publicado em livros e revistas especializadas ou disponível em manuscritos inéditos de museus e bibliotecas. Não fui recolher

\footnotetext{
${ }^{183}$ CALVINO, I., Fábulas italianas, p. 12.

${ }^{184}$ Ibid., p. 9.

${ }^{185}$ Ibid., p. 13.
} 
pessoalmente as histórias no regaço das velhotas; e não porque não existiam mais na Itália "lugares de conservação", mas porque, com todas aquelas coletas dos folcloristas, sobretudo do século XIX, já dispunha de uma grande massa de material no qual trabalhar, e tentativas de coleta original talvez não trouxessem resultados apreciáveis (...). E, além do mais, afinal de contas não é meu campo de trabalho, é um trabalho que exige que saiba fazê-lo, exige que se saiba ganhar a confiança do próximo, e eu já iniciaria com a prevenção de que as pessoas têm mais o que fazer do que me contar fábulas ${ }^{186}$.

Em determinado ponto da introdução, Calvino já parecia prever as críticas que seriam feitas a seu método de recolhimento e tradução. A missão dada a ele desagradaria, inevitavelmente, a muitos intelectuais: havia aqueles que defendiam a veracidade da cultura popular, como Pasolini, e o julgariam por ter traduzido as fábulas do dialeto para o italiano literário e ainda aqueles que desconsideravam a ideia de "cultura popular", e que o acusariam de ter sido pouco audaz em seu trabalho.

Ele se pronunciou sobre a questão da sua intervenção nos textos, considerada por ele o ponto mais fundamental do seu trabalho e o que geraria mais críticas:

\begin{abstract}
Discuto a primeira objeção, que prevejo que venha a ser a fundamental, a da legitimidade de minha intervenção nos textos. É claro que tentar traduzir cantos populares dialetais seria tarefa absurda: lá está o verso, a palavra que conta. A fábula goza da maior traduzibilidade que é privilégio ( e, se quisermos, limite) da narrativa; e este livro nasceu com a intenção precisa de tornar acessível a todos os leitores italianos (e estrangeiros) o mundo fantástico contido em textos dialetais de difícil decifração para muitos. As antologias em dialeto já existem (embora não sejam de fácil localização); desejo que meu livro desperte em alguns leitores a vontade de ir procurá-las e lê-las (... $)^{187}$.
\end{abstract}

O objetivo de Calvino, desse modo, não era o de preservar as fábulas, já que para ele outros mais capacitados o fizeram anteriormente. Sua intenção era, por outro lado, divulgar essas histórias, tornando-as acessíveis por meio da tradução, e retirando-as das prateleiras dos arquivos e bibliotecas dos folcloristas. Calvino parecia aceitar e admitir as suas limitações quanto ao trabalho etnográfico; talvez preferisse realizar um trabalho que fosse acessível por considerá-lo de maior utilidade para as suas pretensões. Nesse ponto, fica clara a

\footnotetext{
${ }^{186}$ Ibid., p. 16.

${ }^{187}$ Ibid., p. 19.
} 
sua postura agregadora, tendo sempre em mente a facilidade de comunicação. Outro ponto importante que deve ser levado em consideração é que Calvino muito provavelmente foi escolhido para essa missão de se aventurar nas fábulas por sua trajetória como intelectual na Itália, que, apesar de recente, era promissora, e mesmo por ser um freqüente colaborador da editora Einaudi, que publicaria a obra. Em 1956 saiu a primeira edição.

No ano seguinte, Pasolini publicou um ensaio crítico sobre as Fábulas Italianas, intitulado Calvino. Tal como havia antevisto Calvino na introdução do livro, prevendo as futuras críticas. Era natural a intervenção pasoliniana, visto que ele vinculou sua trajetória intelectual a pensar questões sobre a cultura dita popular. O ensaio em questão começa por tratar do problema da etnologia. Pasolini coloca ao leitor a dificuldade que envolve o trabalho do etnólogo em entender os significados inerentes a uma realidade desvinculada da sua, e que, na verdade, estariam relacionadas a uma funcionalidade relativa ao mundo mágico do qual o mundo civilizado já havia se esquecido. Desse modo, ele desenvolve o seu ensaio definindo o que entende por cultura inferior: "nas culturas históricas inferiores permanece qualquer coisa de um mundo desaparecido, superado pelos homens, e que, como disse Croce, permanece no homem histórico sob a forma de um momento ideal: a categoria da categoria da intuição" ${ }^{188}$.

O que estava em jogo para Pasolini à época da escrita de seu texto era problematizar a relação do etnólogo "civilizado" diante das culturas inferiores ao selecionar e catalogar as fábulas dialetais italianas, tal como era o caso do projeto encabeçado por Calvino. Para ele, o erro da obra começaria em sua apresentação, escrita pelo crítico literário Emílio Cecchi. Essa apresentação cairia no erro de interpretar a cultura dialetal como um "seixo colorido" ou uma "campanha no Congo", ou seja, predestinada ao prazer dos homens (dos homens "civilizados"), como se por trás dela não houvesse uma realidade, um sentido verdadeiramente humano, vinculado a formas dos homens se organizarem e se relacionarem. No entanto, o prazer com o qual Cecchi apresentava a obra não seria semelhante ao que ele, Pasolini, sentiu diante de sua primeira experiência junto à população de

188 "Nelle culture storiche inferior permane qualcosa di quel mondo scoparso, superato dall'uomo, e che come, come dice Croce permane nell'uomo storico sotto forma di momento ideale: la categoria dell intuizione" (PASOLINI, P. P., Calvino. In: Saggi sulla letteratura e sull'arte, p. 691). 
Friuli, como vimos anteriormente? O que Pasolini acusaria Cecchi é que, além do regozijo, ele não compreendia - ou não queria compreender - a funcionalidade daquelas fábulas para a população campesina italiana.

Após apresentar sua crítica à apresentação do livro, Pasolini parte para a análise do trabalho de Calvino. Este começa por ser comparado aos irmãos Grimm (chamado de "Grimm italiano"). As fontes das quais Calvino fez uso foram as coletas feitas pelos folcloristas italianos do século XIX e que integram os arquivos de Pitrè, a Biblioteca de Comparetti, a de D’Ancona entre outros. De acordo com Pasolini, tal período científico constituiu um corpus material muito bom acerca das fábulas, porém o trabalho em cima do recolhimento,

(...) deveria ser ininterrupto, pois sem solução de continuidade é a história oral de um texto: e cada nova abrasão, interpolação ou contaminação, ainda que mínima, cria, na verdade, um texto novo. Significa que o corpus que possuímos é aquele das fábulas italianas como se contava entre o povo italiano durante os últimos decênios do século XIX ${ }^{189}$.

Nesse ponto, ele já revela a sua crítica ao trabalho de Calvino, que admitiu em seu texto de introdução ao livro, ter se valido do trabalho dos folcloristas do século XIX para realizar suas pesquisas. Portanto, pela interpretação pasoliniana, o trabalho realizado por Calvino foi o de recolher a tradição oral dos contos dialetais de acordo com a visão do século XIX, cujo conteúdo já havia se modificado certamente. No mínimo, o que Pasolini esperava conter naquele trabalho era um recolhimento e uma catalogação atualizada das fábulas contemporâneas. Calvino, até esse momento do texto, parecia ser criticado por não ter se comportado como um verdadeiro etnólogo, por não realizar o recolhimento in loco do seu material, não ter vivenciado o contato com a realidade campesina em sua essência, o que era fundamental à concepção de pesquisa pasoliniana. O segundo erro que Pasolini acusava Calvino de ter cometido, e esse mais grave, foi o de ter traduzido as fábulas da língua dialetal ao italiano literário,

\footnotetext{
189 "dovrebbero essere ininterrotte, perchè senza soluzione di continuità è la storia orale di um texto: e ogni nuova abrasione, interpolazione o contaminazione, sai purê minime, creano in realtà um texto nuovo. Sicchè il corpus che noi possediamo è quello delle fiabe italiane come si raccontavano dal popolo italiano circa negli ultimi due decenni dell'Ottocento" (Ibid., p. 693).
} 
Sem a pretensão científica: a qual seria certamente descartada qualquer possibilidade de tradução, primeiramente, por oferecer o texto da sua integridade dialetal, aquele material de outra cultura, fisicamente e esplendidamente diverso de qualquer material elaborado na língua italiana literária ${ }^{190}$.

Assim, segundo a concepção de Pasolini, Calvino errou duas vezes: ao não coletar as fábulas e tê-las traduzido ao italiano. O problema que se coloca para Pasolini é grave. Sua concepção de intelectual jamais admitiria que um pesquisador de gabinete, como Calvino, fizesse uso de fontes ultrapassadas principalmente se as fontes estivessem dispostas de um modo mais atualizado, dentre os grupos campesinos - somado ao problema da tradução. Ao traduzir, seu autor teria criado um novo texto, ou, como Pasolini mesmo afirmou, "a obra de Calvino deve, portanto, ser julgada internamente, restando dentro do seu sistema, o qual se articula somente sua operação, neste caso extravagante, gratuita, do pastiche, nada histórico, de tradução" 191. A análise pasoliniana identifica operação realizada em Fábulas Italianas, portanto, não como um trabalho de tradução, mas uma imitação mal feita, cujo resultado deu origem a um texto artificial, que não refletia a realidade da população campesina dialetal. É possível comparar esse ponto de vista adotado por Pasolini em relação às fábulas com aquele que Dante defendeu em seu tratado De Vulgari Eloquentia. Assim como Dante admirava o caráter mutável da língua vulgar (que vivia em constante atualização em função dos usos), definindo-a como uma "língua natural", a Pasolini interessava que Calvino ao menos valorizasse as transformações pelas quais as fábulas passavam, e fosse recolhe-las pessoalmente.

Analisar a questão das fábulas é uma parte importante daquilo que se pretendeu desenvolver no presente trabalho, na medida que tal ponto da querela entre os autores torna possível ilustrar como o pensamento de Pasolini quanto à cultura dialetal não se limitou à poesia, tendo sido ela a etapa inicial para ele construir uma ideia de cultura, pensada através da sua relação com o dialeto. É interessante destacar o momento no qual ele definiu, em uma entrevista de 1975,

\footnotetext{
190 "Senza pretesa scientifica: la quale avrebbe senz'altro scartato ogni possibilita di traduzione, anzitutto, per offrire $i$ testi nella loro integrità dialettale, quale materiale d'altra cultura, fisicamente e splendidamente diverso da qualsiasi materiale elaborato nella língua nella língua italiana letteraria" (Ibid., p. 693).

191 "L'opera di Calvino va dunque giudicata dall'interno restando dentro il suo sistema, il quale si empernia soprattutto sull'operazione, in questo caso stravagante, gratuita, da pascticheur, non da storico, del tradurre” (Ibid., p. 693).
} 
serem suas pesquisas sobre cultura dialetal motivadas "pelo gosto de uma investigação arcaica" ${ }^{192}$ : ele se comporta como um pesquisador diante de um objeto raro e delicado. Era necessário criar um método que não danificasse esse objeto.

\subsubsection{A língua dialetal e a língua média}

Um grande problema da linguagem ao longo do século $\mathrm{XX}$, principalmente a partir dos anos 50 (como explicitado anteriormente) é a questão da língua (ou línguas) na Itália. Pasolini apontava como característica principal dessa variedade linguística a ameaça que ela representava à unidade nacional italiana, pois criava um problema quanto à comunicação entre as pessoas. Dessemodo, a divisão linguística era marcada pelo seu poder de distinguir social e economicamente a Itália, provocando, por sua vez, a diferenciação comunicativa. Ao longo dos anos 60 as discussões entre Calvino e Pasolini foram marcadas por questões referentes às línguas existentes na Itália e o que elas afetavam as relações sociais entre os italianos.

No ensaio Novas questões linguísticas, Pasolini põe ao leitor o problema da Koiné literária entre aqueles que faziam uso dessa língua. A definição dessa palavra grega, segundo o entendimento pasoliniano, era identificada como aquela língua fundada pela burguesia, e que na Itália era parte do projeto burguês de fundar uma língua nacional através da literatura. $\mathrm{O}$ resultado de tal projeto, no entanto, só acrescentou ao país uma nova língua, sendo ela também fragmentada. A essa língua, Pasolini deu o nome de "italiano médio". Para ele, tal língua teria fracassado em seu projeto de uma Koinè, já que

o italiano médio se apresenta como uma entidade dual, uma santíssima dualidade: o italiano instrumental e o italiano literário.

A osmose com o latim, as várias estratificações devidas a diacronias históricas, a tendência à síntese, o prevalecer da expressividade sobre a comunicação, a coexistência de muitas formas confluentes (...) definem em conjunto o italiano literário médio (...) São duas escolhas possíveis para exprimir fundamentalmente a mesma experiência histórica e de vida. Assim, se eu tivesse que definir viva e sinteticamente o italiano, diria que se trata de uma língua não, ou imperfeitamente, nacional, que cobre um corpo histórico-social fragmentário, seja

${ }^{192}$ PASOLINI, P. P., As últimas palavras do herege: entrevistas com Jean Duflot, p. 24. 
no sentido vertical, seja no sentido extensivo (as diversas vicissitudes regionais, que produzem as várias pequenas línguas virtuais concorrentes, os dialetos [... $]^{193}$.

Ou seja, Pasolini entendia que a língua média não se tornaria a língua nacional em virtude de não ser ela o resultado das experiências históricas dos diversos grupos sociais existentes na Itália recém-unificada, mas somente reflexo da experiência histórica da burguesia e que, por esse motivo, não soube identificar-se com a nação recém-formada. Além disso, ela seria dotada de uma "força centrífuga", capaz de repelir todas as outras línguas, formando assim uma hierarquia. É a partir de tal categorização que surgem os níveis linguísticos citados por Pasolini e já anteriormente mencionados: a língua hermética, a média e a baixa (dialetal).

Munido desses critérios, ele vai analisando a relação dos autores com tais níveis linguísticos, mas, quase todos os escritores citados usam, no máximo, um nível médio rebaixado e somente o fazem quando a história é sobre um personagem popular. Ou seja, o elemento dialetal/ popular é excluído por boa parte dos autores, não realizando uma "verdadeira e própria mimeses". Entre os autores analisados, estava mais uma vez Italo Calvino. Pasolini conclui que relação de Calvino com esse assunto linguístico como uma "aceitação da normalidade". Ou seja, nesse autor, segundo o ensaio, não havia nem um senso de humor quando ele se colocava a favor das mudanças. Calvino, de acordo com as críticas pasolinianas, não questionaria o processo de alteração da língua, não se portando como crítico de seu tempo.

Na metade do texto, Pasolini admite um estado de crise no mundo literário italiano em função de duas condições identificadas por ele: o desmantelamento dos dialetos - que além de um problema literário era também um problema social -, o fracasso do empenho social para a criação de uma língua nacional através da literatura, e a desqualificação das vanguardas literárias italianas do século XIX como movimentos inovadores. Ele ainda acrescenta:

Esta crise linguística - e não apenas estilística - é a denúncia de que está acontecendo na nossa sociedade algo profundamente novo. Antecipando todas as

193 PASOLINI, P. P., Novas Questões Linguísticas. In: Diálogos com Pasolini. Escritos 19571984, p. 18. 
outras observações que poder-se-iam fazer -por exemplo as indicações dadas nesse sentido pelas vanguardas -, não hesitaria em radicalizar essa crise através daquela que Fortini (citando Maiakóvski) chama de fim do mandato do escritor, ou seja, o fim não só do compromisso, mas de todos aqueles conceitos - de resto absolutamente impopulares -que se apresentaram como substitutos ou aspectos evoluídos de compromisso ${ }^{194}$.

O que Pasolini chama de fim do compromisso do escritor está relacionado ao comprometimento do autor com as questões sociais que envolvem seus personagens em relação ao mundo real. Ignorar a fala de um personagem de origem humilde como sendo uma fala provavelmente popular, e utilizar um italiano literário rebaixado, por exemplo, significa ignorar as especificidades sociais e culturais daqueles grupos que (em tese) são representados pelo personagem. Uma forma de o escritor se comprometer com a veracidade de seus personagens, por outro lado, seria ele realizar aqui que Pasolini definiu como "pesquisas plurilinguísticas, dialetais, experimentais", que colocariam o escritor e sua obra em contato com a realidade de um personagem de classe inferior à sua, evitando, assim, um artificialismo na descrição e na fala. Contra essas pesquisas, teriam se colocado os "puristas" de tendência conservadora, que valorizavam o aspecto mais puro da linguagem (linguagem culta), sem influência de outras variantes.

Mais uma vez é possível pensar nas influências da educação poética pela qual passou Pasolini, tendo como expoentes principais Dante e Pascoli, em virtude da "mistuta de línguas". A noção de plurilinguismo como sinônimo de realidade se estendeu da poesia para a atividade crítica/intelectual como um todo.

Nesse ponto do trabalho é importante levantar uma questão - repensando elementos que já foram apresentados aqui -, buscando respondê-la logo em seguida, e que permite pensar sobre o plurilinguismo: se Pasolini valorizava essa mistura estilística e lexical, por que criticar o procedimento de construção do italiano médio? O grande incômodo de Pasolini era a ausência de reflexão sobre os métodos, não levando em conta a perspectiva das "classes mais baixas" ao longo do processo, já que essa linguagem era imposta verticalmente, ou seja, de cima para baixo.

${ }^{194}$ Ibid., p. 23-24. 
Entende-se, a partir de seus argumentos, que Pasolini propunha e indicava como melhor método para os escritores produzirem uma literatura mais realista e natural algo semelhante ao que ele próprio se portava diante daquele que era seu objeto de estudo há anos (notadamente a cultura dialetal): uma imersão na realidade e na cultura, de modo a minimizar a distância entre o literato e seu objeto, tornando a narrativa decorrente desse contato menos artificial.

A solução apontada por Pasolini para compreender de fato quais são as reais causas dessa crise literária experimentada pela Itália seria semelhante ao que ele entende por ser o trabalho das novas vanguardas literárias italianas: um processo menos literário e mais sociolinguístico. Ao se voltar para o fenômeno sociológico, Pasolini deparou-se com o problema social da língua que é o processo de instrumentalização da linguagem, verificada, segundo ele, principalmente na linguagem jornalística e televisiva. Assim, cria-se uma funcionalidade linguística, especializada para cada tipo de setor que adquire sua própria linguagem. Por exemplo:

No que nos diz respeito, a linguagem televisiva parecia ter disposto a sua função didática na direção de um belo italiano, gramaticalmente puro, até um purismo fundamental; agora a função didática da televisão parece dirigir-se a uma normatividade de gramática e de léxico não mais purista, e sim instrumental: a comunicação prevalece sobre qualquer possível expressividade, e o pouco de expressividade tola e pequeno-burguesa que ainda permanece é em função de uma instrumentação brutal.

E oportuno fazer outra observação, mais marginal porém não menos interessante, sobre a linguagem televisiva: a monotonia dos esquemas da típica amostra televisiva que é o telejornal. Nem parece língua italiana (...) Parece que ouvimos um locutor francês ou tchecoslováquio ${ }^{195}$.

Por essa longa citação pode-se ter dimensão dos elementos que incomodam Pasolini nesse novo tipo de linguagem típica da Itália a partir de meados do século, a comunicação acima da expressividade e a desnacionalização da língua italiana. A industrialização italiana teve como um dos sintomas a entrada de vocabulários estrangeiros à língua italiana, que contribuíam à aniquilação das línguas dialetais locais e que acabavam por tornar a Itália uma

195 PASOLINI, P. P., Novas Questões Linguísticas. In: Diálogos com Pasolini. Escritos 19571984, p. 27. 
região que ia se descaracterizando, inclusive a sua pronúncia. Essa linguagem era transmitida em larga escala por meio da televisão às pessoas de "pouca cultura" que reproduziam a linguagem com a pronúncia propagada pelos veículos televisivos. Esse seria o reflexo da tecnologia e da industrialização que se tornaram as substitutas das Universidades - antigos centros elaboradores e unificadores da linguagem.

Para Pasolini tal processo era mais grave que a ação das línguas burguesas que antes ignoravam a expressividade das línguas dialetais - diante do processo de criação de uma língua nacional. A linguagem industrial, ao contrário, ao utilizar os meios de comunicação mais eficientes de veiculação em massa, como a televisão, conseguia transformar os princípios formadores dos dialetos através de suas tecnicizações. Outro elemento fundamentação a essa mutação diagnosticada por ele seria o das transformações lingüísticas através dos ambientes de trabalho nas indústrias, e que influenciariam a linguagem dos operários. Desse modo, ele sinaliza que

\begin{abstract}
A língua técnico-científica não se alinha com todas as estratificações precedentes, mas se apresenta como homologadora das outras estratificações linguísticas, e naturalmente como modificadora no interior das linguagens. Ora o princípio de homologação esta evidentemente em uma nova forma social da língua, em uma cultura técnica em vez de humanista ${ }^{196}$.
\end{abstract}

O esforço entre aqueles que elaboraram a língua média no sentido de forjar uma língua nacional constituiu-se natural no caso da linguagem tecnológica, que homologava os comportamentos e vocabulário em torno de uma formatação linguística que privilegiava a comunicação. Nesse sentido, Pasolini conclui:

Quero dizer que enquanto a grande e pequena burguesia de tipo paleoindustrial e comercial nunca conseguiu identificar-se com a sociedade italiana como um todo, e fez simplesmente do italiano literário a própria língua de classe, impondo-a de cima para baixo, a tecnologia nascente do Norte se identifica hegemonicamente com toda a nação e elabora, portanto, um novo tipo de cultura efetivamente nacional $^{197}$.

Muitos intelectuais se envolveram na discussão sobre esse tema na Itália naquele período, como Italo Calvino, com que ele já havia travado uma querela

\footnotetext{
${ }^{196}$ Ibid., p. 30.

${ }^{197}$ Ibid., p. 30.
} 
anos antes sobre as fábulas. A resposta de Calvino veio em um ensaio publicado no Il Contemporaneo em janeiro de 1965, intitulado O Italiano, uma língua entre outras línguas. Em apresentação à edição de 1980, Calvino introduz esse ensaio afirmando a incoerência de Pasolini, que anos antes,

(...) negara a existência do italiano como língua falada de uso geral, anunciando que agora havia mudado as suas convicções: a língua italiana tinha começado a existir, e era "a língua da produção e do consumo", surgida nas grandes empresas, que "homologa todo tipo de linguagem da Koinè italiana"

Nessa réplica Calvino adota uma perspectiva diferente da pasoliniana (a do intelectual engajado), respondendo sob uma lógica editorial:

Sei muito bem que essas afirmações deveriam ser fundamentadas em análises que poderia esboçar só de maneira aproximativa e que solicitariam de todo modo a confirmação de especialistas. Por enquanto, limito-me a antecipar, a título de hipótese, algumas observações empíricas: a editora de livros italianos e estrangeiros ${ }^{199}$.

A partir desse ponto de vista, Calvino traça sua argumentação, tentando demonstrar ao leitor os aspectos positivos do italiano. O primeiro deles é a flexibilidade da língua, que "permite-nos traduzir das outras línguas um pouco melhor do que seria possível fazê-lo em qualquer outra língua”. Em contrapartida, o italiano não seria uma língua facilmente traduzida para outros idiomas ${ }^{200}$. Ainda no início do texto, Calvino admite que o italiano não conseguia introduzir-se na realidade da população dialetal, evidenciando a falha no estabelecimento de uma língua nacional:

(...) sobretudo no caso das línguas que tem uma dimensão de gíria, mais o italiano falha porque no âmbito pop, brincalhona burguesa sempre é maçante e - como o costume muda e o tempo todo - imediatamente "datado". (O "italiano médio", como bem afirma Pasolini, é uma "língua impossível, infrequentável") ${ }^{201}$.

O problema da tradução parece ser aquele que mais preocupa a Calvino, afinal, pensando como editor, tal questão torna-se essencial. Em termos

\footnotetext{
${ }^{198}$ CALVINO, I., Italiano, uma língua entre outras línguas. In: Assunto encerrado: discurso sobre literatura e sociedade, p. 140.

${ }^{199}$ Ibid., p.141.

${ }^{200}$ Ibid., p. 141.

${ }^{201}$ Ibid., p. 142.
} 
mercadológicos, podemos imaginar os inúmeros problemas que poderiam ser identificados pela perspectiva calviniana, mesmo que isso não fique evidente em seu texto. A começar pela falta de interesse do mercado editorial internacional em traduzir um texto, que se tornaria impossível ao entendimento de um leitor que não estivesse familiarizado com as especificidades da cultura italiana. Outro problema inerente a essa constatação é a dificuldade entre os próprios italianos em compreender uma literatura que se diz nacional, ou seja, comum a todos. No entanto, este último aspecto não aparece no texto como uma causa que preocupe a Calvino, ao contrário do que se pode perceber nas críticas pasolinianas. Nesse ponto de seu ensaio, o autor minimiza a questão da traduzibilidade italiana concluindo: "quem lê literatura traduzida já sabe que está fazendo alguma coisa aproximativa" 202 .

Enquanto no italiano literário o problema seria resolvido a partir de uma pré-disposição do leitor em aceitar as limitações de uma tradução, o mesmo não ocorre com a linguagem da comunicação, ou seja, aquela destinada aos periódicos e televisão, incluindo também os ensaios jornalísticos, que versam sobre diversos temas. A linguagem destinada a esses tipos de discursos deveriam privilegiar a comunicação, vislumbrando um público leitor em proporções internacionais e, exatamente por isso, o cuidado com a escrita deveria levar em conta uma possível tradução. A afirmação de Calvino nesse ponto do seu texto permite ao leitor imaginar que sua proposta de linguagem comunicativa seja a linguagem tecnológica, que Pasolini tanto criticava em seus ensaios. No entanto, a argumentação que ele desenvolve ao longo de texto não é completamente oposta à perspectiva pasoliniana, o que se torna mais evidente no momento em que ele começa a justificar sua ideia:

Aonde eu quero chegar com esta minha conversa? Estou querendo dizer que, antes de escrever na própria língua, é preciso pensar em outra língua, ou em espécie de esperanto que sirva para todos? Uma pretensão dessa espécie, para nossa como para qualquer outra língua, equivaleria a castrar o pensamento, achatá-lo, privá-lo da capacidade de destacar nuances, desenvolver intuições sutis. As línguas nacionais, embora todas elas estejam hoje em crise sobreviverão 
ainda por alguns séculos, precisamente porque cada língua tem limites, mas também possibilidades que são exclusivamente suas ${ }^{203}$.

Desse modo, Calvino explicita ao seu leitor que não se deve privilegiar a tradução à criatividade, porém, buscar conciliar ambas a partir de um cuidado com a escrita, com a escolha das palavras. Certo grau de traduzibilidade, para ele, poderia enriquecer o texto com certa "complexidade linguística".

Quanto à linguagem tecnológica, esse tema será desenvolvido nos últimos parágrafos desse ensaio, à medida que o autor estabelecer como interlocutor o próprio Pasolini. Mais do que em qualquer outro momento do texto, é no final do ensaio que surgem as respostas àquelas provocações. Primeiramente, Calvino posiciona-se contra a perspectiva pasoliniana de que a chamada "língua tecnológica" tenha conseguido unificar hábitos e comportamentos a partir da lógica do trabalho urbano; ao contrário, Calvino identifica naquela linguagem um fracasso. Já o vocabulário especificamente comunicativo, ou seja, o da televisão, é definido por ele como pobre semântica e, exatamente por isso, privilegiado pelos meios de comunicação. Assim, ao que parece, Calvino se aproxima da posição defendida por Pasolini em suas conclusões. Contudo, logo em seguida ele pontua,

\begin{abstract}
Minhas conclusões, portanto, estão em desacordo com as conclusões de Pasolini (...). Quanto à afirmação de que Pasolini que "nasceu o italiano como língua nacional", saúdo-a como nova e bem vinda página de sua poética, mas não compartilho dela como um fato. Talvez porque, antes, nem sequer compartilhava da afirmação de que o italiano não existia (o italiano existe como fenômeno linguístico único em seu gênero, diferente do fenômeno francês, do inglês etc., e estes por sua vez diferentes entre si) nem nunca pensei que os dialetos (esses dialetos decaídos, desgastados, enfáticos, corrompidos) fossem, ao contrário, a saúde e a verdade. Mas também aquilo do que mais compartilho do discurso de Pasolini -a intolerância ao "italiano médio" - me fez recuar a ilusão de que tenha acontecido alguma coisa radicalmente nova ${ }^{204}$.
\end{abstract}

Nesse parágrafo de conclusão Calvino apresenta pontos importantes à sua querela com Pasolini. Primeiramente, ele se justifica estando mais próximo às de seu interlocutor que aquele poderia supor. Enquanto Pasolini marca a diferença, Calvino prefere minimizar as distâncias, concordando com a opinião do outro

\footnotetext{
${ }^{203}$ Ibid., p. 144

${ }^{204}$ Ibid., p. 146
} 
quanto à questão do fracasso do italiano médio. No entanto, Calvino não recua sobre a língua dialetal, assunto no qual ele marca claramente sua oposição a Pasolini, ao afirmar sua decadência e cansaço, fato, aliás, que pode suscitar em seus leitores certo estranhamento, visto que anos antes ele havia se envolvido e demonstrado encantamento com a cultura popular dialetal, ao traduzir as fábulas para o italiano literário. A explicação a essa posição aparentemente dúbia pode ser aqui interpretada não como uma desqualificação da cultura dialetal, mas a necessidade identificada por Calvino em atualizar a cultura dialetal, retirando-a do isolamento linguístico, como o novo substituindo o velho.

Em fevereiro de 1965, no ensaio Antilíngua, Calvino dá continuidade aos seus argumentos contra Pasolini, só que agora com estilo mais irônico: ele nomeou a linguagem da comunicação (língua tecnológica) como uma "antilíngua", em "conformidade" com o pensamento pasoliniano, caracterizando-a como "um terror semântico". O leitor, no início do ensaio, pode estranhar esse posicionamento do autor, e muito provavelmente se perguntar se Calvino o manterá até o fim. Na segunda página, contudo, Calvino retoma suas concepções anteriores, passando então a defender suas verdadeiras opiniões. O objetivo do início do texto parece ser demonstrar que o terror de um posicionamento contrário a toda e qualquer manifestação da língua - como é o de Pasolini - se trata de um exagero, para em seguida mostrar as características positivas de tais transformações. Para ele,

\begin{abstract}
Se a linguagem "tecnológica" sobre a qual Pasolini escreveu (isto é, plenamente comunicativa, instrumental, homologadora dos diferentes usos) se enxerta na língua, só poderá enriquecê-la, eliminar dela irracionalidade e pesos, dar-lhes novas possibilidade (de início apenas comunicativas, mas criarão, como sempre acontece, uma área própria de expressividade); se essa mesma linguagem se enxerta na antilíngua, sofrerá imediatamente um contágio mortal, e também os termos "tecnológicos" vão se tingir da cor do nada ${ }^{205}$.
\end{abstract}

A ideia de uma antilíngua parece, portanto, ser uma construção não de Calvino, mas sim de Pasolini em cima do fenômeno da industrialização diante da cultura italiana, atingindo não só os dialetos, como também o italiano médio, este último, aliás, irreconhecível em ensaios anteriores para Pasolini. O 
posicionamento de Calvino aparenta movimentar-se sempre à frente do de seu interlocutor: enquanto ele defendia a validade do italiano (literário que faria parte do italiano médio), o outro o renegava; quando ele determinava que o italiano estava morrendo, ou outro enxergava nele uma atualização por meio dos elementos tecnológicos.

Para Calvino, a linguagem tecnológica não era morte, mas a modernidade típica do movimento das sociedades ao longo do tempo. Culturalmente, ele identifica-a como "uma conquista de novas catergorias lexicais, ordens mais precisas que as existentes, estruturação mais funcional do pensamento por meio da frase" ${ }^{206}$. Ele dava grande relevância à necessidade prática da língua a qual não estaria exatamente vinculada à tradição dialetal. Calvino dá o exemplo de uma simples ida ao mecânico. O tipo de vocabulário utilizado por aquele trabalhador no momento em que exerce, mesmo que sua língua original seja a dialetal, seria permeada por novas palavras, típicas de sua função.

Calvino pretendeu mostrar a inviabilidade da proposta pasoliniana, já que a chamada "linguagem tecnológica" era uma transformação natural da linguagem diante das novas necessidades da vida cotidiana. Pode-se entender a partir de seus argumentos que para ele não seria possível uma sociedade que se transformava manter o vocabulário estritamente fiel à tradição dialetal campesina.

Em Diário Linguístico, Pasolini desenvolve sua réplica aos textos de Calvino. Sua resposta pretende esclarecer alguns pontos que aparentemente estiveram obscuros no texto anterior, camuflando suas reais intenções. A questão lingüística, segundo ele, era apenas um exemplo de uma situação mais ampla, sobre a política italiana e, mais especificamente, sobre os males do capitalismo na Itália. E é nesse sentido que ele encaminha seu novo ensaio: menos literário e mais político. A perspectiva defendida nesse novo ensaio é a de que o capitalismo havia tomado uma proporção social grande, levando "à monstruosidade de uma comunicação de alienados no plano linguístico". Tal situação seria o resultado de uma postura passiva da burguesia diante das mudanças que ocorriam nas relações de trabalho e economia, ignorando as consequências cultuais do fenômeno ao privilegiarem somente os aspectos políticos e econômicos. O posicionamento 
socialista, por sua vez, era diagnosticado por Pasolini como passividade diante de uma possível dominação cultural burguesa.

A partir desse cenário apresentado, o autor, então, dirige-se aos argumentos dados por Calvino em seu ensaio. A crítica que ele tece ao seu interlocutor é a indiferença com a qual aquele se dirige a questão das línguas dialetais (definidas por Calvino como cansadas), esquecendo que a supressão dialetal é somente uma entre as muitas consequências do problema político e econômico decorrentes do consumismo industrial, que vendia não só produtos, mas também uma nova cultura. A opinião de Calvino, segundo Pasolini, estaria atrelada a uma preocupação com a comunicação e não com a expressividade, entendida nesse ensaio como resultado de uma vinculação calvinista ao internacionalismo que tornava natural a ideia de adaptar os dialetos. Quanto à linguagem usada pelo jornalismo, ela é reafirmada nesse ensaio com mais ênfase, acusada de negativamente homologar os hábitos e cultura italiana.

Diante do que foi exposto até aqui, percebe-se que estava em jogo não somente a questão linguística, mas uma ideia de cultura, de entendimento de mundo entre os homens e a transformação dos italianos não mais por padrões tipicamente italianos, mas sim europeizantes. Enquanto Pasolini tratava o tema de maneira política, o outro via o processo de transformação da língua com naturalidade, parte de transformação que ocorria não somente na Itália, como em todo mundo. Calvino traduzia as fábulas italianas, enquanto seu opositor procurava preservá-los desde a juventude através das inúmeras linguagens das quais ele fazia uso, como a poesia, o romance e o cinema. Apesar da contemporaneidade, de uma trajetória intelectual muito semelhante, ao analisar aquilo que cada um desses autores defende, pode-se ter uma ideia de Calvino como um intelectual que soube entender seu tempo, e Pasolini como um pensador preso ao passado. Tais posições ultrapassaram as querelas dos anos 60, permanecendo vivas ao longo da década de 70.

Em ensaio publicado em 1974 em Paese Sera, intitulado Carta aberta a Italo Calvino, Pasolini sintetiza bem qual era a motivação a essa defesa passional que ele fez da cultura popular dialetal ao longo de sua vida: certa nostalgia de uma realidade que ele vivenciou em sua juventude. Esse texto era uma resposta aos 
comentários - não só de Calvino, como também de muitos de seus contemporâneos - de ser ele tomado por uma nostalgia, considerada por seus interlocutores como negativa. Calvino acusava-o de ter saudade da "Italietta", definida por ele como "pequeno-burguesa, fascista, democrata-cristã (...) sua cultura é um humanismo escolástico formal e vulgar", e exatamente por isso, impossível de provocar-lhe saudades. As justificativas parecem, no entanto, destinadas não somente aos comentários de Calvino, como também um desabafo:

Você deseja que eu tenha saudade de tudo isso? Por aquilo que me compete pessoalmente, esta "Italietta" foi um país de militares que me prendeu, processou, perseguiu, atormentou, linchou por quase duas décadas (...). Pode ser que eu tenha tido aquele mínimo de dignidade que me permitiu esconder a angústia de quem, por anos e anos, esperava todo dia a chegada de uma citação do tribunal e tinha horror de olhar as bancas de revista para não ler, nos jornais atrozes, notícias escandalosas sobre a própria pessoa ${ }^{207}$.

Pasolini sentia-se perseguido e isolado em seu próprio país, sensação que, no entanto, pode-se concluir que foi provocada não só por seus críticos, mas também uma decisão pessoal e profissional. Ao invés de conviver com a intelectualidade da "Italietta", Pasolini optou por se integrar ao mundo camponês e ao mundo subproletário a partir de sua experiência com as borgate italianas . Assim como ele, o mundo elegido para sua imersão teria a vantagem de não coincidir com a Itália unificada, a não ser pela questão territorial, já que "o universo camponês (...) é um universo transnacional: que, ademais, não reconhece nações" ${ }^{208}$. Desse modo, o mundo eleito por Pasolini desde a sua juventude (a partir do contato com a população do Friuli) reconfigurou-se ao longo dos anos de sua trajetória intelectual, caracterizada justamente pela preservação e valorização da realidade dialetal. Ao final de sua vida, no entanto, ele se encontrava cansado, desiludido quanto ao sucesso de preservar a linguagem e a cultura dialetal.

O saudosismo pasoliniano era, assim, em relação a um mundo que já havia acabado, do qual ele buscava os resquícios nas sociedades do Terceiro Mundo, como em alguns países da África, já que na Itália elas já haviam sido reprimidas por um modelo cultural que moldava o corpo e os comportamentos, e tornava a

${ }^{207}$ PASOLINI, P. P., Mesquinhez da história e imensidão do mundo camponês. In: O desejo anticapitalista em Pier Paolo Pasolini [Acesso em meio eletrônico] 208 Ibid. 
linguagem um mero instrumento de comunicação. Além disso, a cultura italiana transformou-se em um meio de padronização que, conforme descrito anteriormente, é reconhecida por ele como uma "mutação antropológica", ou seja, uma padronização "segundo um código interclassista (estudante igual a operário, operário no Norte igual a operário do Sul): ao menos potencialmente, na ansiosa vontade de uniformizar-se"209.

A partir dessa constatação, espantou-se Pasolini em identificar em seu interlocutor mais uma vez um comportamento conformista em relação à situação da Itália nos anos 70, que foram resultado dessa "mutação antropológica". A decepção que a postura de Calvino causa em Pasolini pode ser explicada muito pela trajetória de ambos, que em muitos momentos cruzaram os mesmos caminhos. Ou seja, havia em Pasolini a consciência dessa semelhança, apesar de as divergentes opiniões entre eles serem anteriores àquele momento, mas de alguns anos antes e, apesar dessas, Pasolini admirava seu interlocutor. O que o espantava era menos a discordância de Calvino e mais o seu não entendimento do papel no qual ele, Pasolini, colocava-se diante do problema da cultura dialetal popular.

Enfim, essa sensação de um estrangeiro dentro de sua própria casa era uma "via de mão" dupla entre Pasolini e os seus contemporâneos. Enquanto a crítica massacrava seu posicionamento, seus trabalhos e seu saudosismo, partia dele também uma vontade de se isolar diante de uma realidade que se configurava ao seu redor, em uma conjuntura marcada por intensas transformações em um curto espaço de tempo. Pasolini cresceu em uma Itália que enfrentava as primeiras transformações típicas da sociedade fascista recém unificada; posteriormente viuse assolada pelas indústrias e a tecnologia, enquanto ele, parado no tempo, aproximava-se cada vez de uma realidade que ele mesmo pouco viveu, envolto em uma passionalidade em torno do clima bucólico e da cultura campesina dialetal italiana.

Assim pode-se concluir que o conjunto de ensaios desenvolvidos por Pasolini ao longo de sua vida foi considerado por muitos de seu tempo como uma estagnação, típica de um autor que aos olhos dos seus contemporâneos era 
identificado por estar à margem do que ocorria na Itália. Modificava-se o tipo, o tamanho do texto, os temas desenvolvidos variavam, porém, o fundo de seus escritos sempre teve como cerne principal o resgate de um mundo distante que caracterizaria a cultura dialetal popular. 


\section{Considerações finais}

A partir do que foi exposto aqui, é inegável pensar a trajetória intelectual de Pasolini sem passar pelas discussões sobre linguagem na Itália. De uma relação afetiva com a língua friulana, Pasolini desenvolveu suas primeiras poesias. O dialeto friulano abriu ao jovem um mundo arcaico representado por essa língua, que desaparecia conforme o uso do italiano ia se popularizando entre os povos campesinos. O friulano confundia-se com o mundo bucólico, onde as pessoas preservavam o contato com a natureza e fundavam assim a sua realidade. Desse modo, em Pasolini construiu-se a ideia de que a realidade era fruto não de uma visão racionalista do mundo, mas sim da experiência, da vivência dos homens e de suas sensações provenientes desse contato com a natureza. Com o pouco conhecimento que o jovem tinha acerca da atividade poética e, inspirado, sobretudo, na poesia provençal, Pasolini compôs seus primeiros poemas em dialeto, que são o resultado dessa inspiração dada pela natureza.

Conforme sua atividade poética ia amadurecendo, assim como ele próprio, Pasolini entrou em contato com um conjunto de referenciais teóricos e poéticos sobre as possíveis origens da poesia. Dante Alighieri, Giambattista Vico, Rousseau, Herder, os teóricos românticos, entre outros. Todos eles contribuíram para que o escritor pudesse fundamentar aquilo que se mostrou ao longo dos capítulos ser seu maior objetivo: pensar a poesia dialetal como a poesia italiana por excelência. Desse modo, Pasolini procurou mostrar como a língua dialetal possuía a mesma dignidade das línguas vulgares que Dante defendeu sobretudo em sua obra De Vulgari Eloquentia. Pasolini se valeu, também, das ideias de Vico, Rousseau e Herder quanto à poesia primitiva, pensando esta como análoga à poesia em dialeto. Tal como os poetas dialetais, os poetas primitivos também foram inspirados pela natureza, e disso resultava a construção da realidade.

Tal como Pasolini, o movimento romântico na Itália também pensava a poesia dialetal de acordo com esses critérios como originalidade e a relação entre a inspiração poética e a realidade. Assim, a poesia dialetal mostrava-se através da 
atividade de estudiosos como Nigra, Pitrè e Tommaseo, como sendo a poesia popular italiana, por excelência. Estabelecia-se, assim, um conjunto de referências que poderiam conferir legitimidade às ideias pasolinianas sobre poesia. Antes dele, um conjunto de pensadores refletiu acerca da poesia proveniente não de uma atitude reflexiva, mas, sobretudo, sensitiva, tendo como elemento crucial a natureza. O primitivo e todos os seus aspectos mitológicos foram resgatados em diversos momentos da análise de Pasolini, no intento de comprovar como suas ideias em torno da poesia dialetal possuíam embasamento.

Todavia, foi em Dante onde Pasolini encontrou a maior inspiração para pensar o seu fazer poético e neste como uma forma de crítica. A ideia que ele desenvolveu, mediado pela leitura de Auerbach, do realismo em Dante foi fundamental para a construção de sua própria ideia de realismo. A poesia realista é o reflexo de uma experiência sensível da realidade. Desse modo Dante teria composto a Divina Comédia, e Pasolini, por sua vez, definido sua relação com a poesia dialetal. Estava em jogo no fazer poético de ambos, a problematização da poesia como atividade ligada às sensações, impressões, o que tornaria imprescindível o contato com seu íntimo e, principalmente, com a natureza. Se a inspiração de Dante foram as línguas vernaculares, a de Pasolini foi a sua experiência com a realidade dos povos campesinos na Itália.

No bojo dessa relação entre o realismo de Dante e o de Pasolini estão aquilo que este definiu como sendo uma "mistura de linguagens", ou seja, um plurilinguagem, no que tange a mistura de léxico e estilo. Essa era para Pasolini a justificativa para definir a obra canônica de Dante como realista. Nesse mesmo sentido, a leitura pasoliniana definia a poesia de Giovanni Pascoli como plurilinguista. Desse modo, foi possível a ele forjar uma tradição de poesia plurilinguista, que se confunde com a noção de poesia realista.

Pasolini conseguiu traçar essas conexões entre filósofos e poetas através da leitura da obra de Benedetto Croce e de Gianfranco Contini. No entanto, apesar de ser amparado pela leitura de inúmeros autores, percebe-se o caráter único da interpretação pasoliniana: por vezes até confusa, sua leitura das referências citadas é feita de maneira a corroborar suas próprias ideias. Assim a obra ensaística de Pasolini é marcada por algumas incoerências e inconstâncias, fruto de uma 
atividade intelectual que carregava um interesse maior: defender uma realidade arcaica, dialetal, que cedia espaço à cultura de uma Itália unificada.

Ora, mas se era o próprio autor quem defendia uma tradição plurilinguista, porque não ser favorável ao surgimento da uma nova língua, nacional? O problema que Pasolini identificava no seu tempo era que o surgimento da língua italiana, bem como daquilo que ele definiu como uma "linguagem tecnológica", levou ao apagamento da língua dialetal, não sendo esse processo, portanto, resultado de uma integração entre as línguas. As novas línguas, ao contrário, refletiam a opressão sofrida pelas classes mais baixas em seus diferentes aspectos. Dessa forma, a opressão linguistica significava também a opressão da possibilidade da construção de um determinado tipo de realidade, rementente aos povos campesinos. A defesa que Pasolini fazia da língua dialetal em seus diferentes aspectos (poéticos, morais e políticos) era a defesa de uma concepção de mundo que morria diante de um processo histórico que não era pensado por ele como natural. 


\section{Referências Bibliográficas}

AMOROSO, M. B. A paixão pelo real: Pasolini e a crítica literária. São Paulo: USP, 1997.

ANDRADE, F. C. A transparência do impossível: lírica e hermetismo na poesia brasileira atual, 2008. $331 \mathrm{f}$. Tese de Doutorado (Doutorado em Teoria da Literatura). Centro de Artes e Comunicação. Universidade Federal de Pernambuco, 2008.

ARISTÓTELES; HORÁCIO e LONGINO. A poética clássica. São Paulo: Cultrix, 2005.

AUERBACH, E. Dante, o poeta do mundo secular. Rio de Janeiro: Top Books, 1997.

cidades, 2007.

Ensaios de literatura ocidental. São Paulo: Duas

Mimesis: a representação da realidade na literatura ocidental. São Paulo: Perspectiva, 2013.

AZEVEDO, C. A. Filosofia da arte e os primeiros elementos para a formulação da filosofia na mitologia. In: Arte e filosofia. Ouro Preto. n. 15. dez. 2003.

BALDACCI, Li. Pasolini e Pascoli, poesia in forma di láurea. Corriere della Sera. Dez. 1993. Disponível em: [ Acesso em meio eletrônico: archiviostorico.corriere.it].

BENJAMIN, W. Goethe. In: Documentos de cultura, documentos de barbárie: escritos escolhidos. São Paulo: Cultrix. EDUSP, 1986.

BERLIN, I. Vico e Herder. Brasília: Editora Universidade de Brasília, 1982.

CALDAS, P. E. Teologia da história: o fundamento do historicismo em Johann Gottfried Herder, 1999. 117f. Dissertação de mestrado (Mestrado em História). Departamento de História. Pontifícia Universidade Católica do Rio de Janeiro, Rio de Janeiro, 1999.

CAMPOS, A. de. Verso, reverso, controverso. São Paulo: Perspectiva, 1978.

CALVINO, I. Assunto encerrado: discurso sobre literatura e sociedade. São Paulo: Companhia das Letras, 2006.

Fábulas italianas. São Paulo: Companhia das Letras, 1992.

CHOMSKY, N. A linguagem cartesiana. São Paulo: Vozes/EUSP, 1972.

CONTINI, Gianfranco. II linguaggio di Pascoli. Milão: Arnaldo Mondadori, 1974. Disponível em:

http://www.classicitaliani.it/pascoli/critica/Contini poesia pascoliana.htm. 
G. Einaudi, 1970.

Varianti e altra linguistica: uma raccolta di saggi. Torino:

CROCE, B. Estetica come scienza dell'espressione e lingüista generale. Roma: Bari Gius Latterza \& Figli, 1906.

e Figli, 1920.

Giovanni Pascoli, studio critico. Roma: Bari Gius Laterza

Latterza \& Figli, 1922.

La filosofia de Giambattista Vico. Roma: Bari Gius

La poesia di Dante. Roma: Bari Gius Laterza e Figli, 1921.

Poesia popolare e poesia d'arte. Publicada em: La crítica. Rivista di Letteratura, Storia e Filosofia diretta da B. Croce. n. 27. 1929. p. 321. Edição Digital: CSI Biblioteca di Filosofia. Universitá di Roma "La sapienza"- Fondazione Biblioteca Benedetto Croce". Disponível em: http://www.fondazionebenedettocroce.it/.

DANTE, A. De Vulgari Eloquentia. Porto Alegre: Tiago Tresoldi Editore, 2011.

DIDI-HUBERMAN, G. Sobrevivência dos vagalumes. Belo Horizonte: UFMG, 2011.

DUARTE, P. Estio do tempo: o amor entre a arte e a filosofia na origem do romantismo alemão. 2009. 277 f. Tese (Doutorado em Filosofia). Departamento de Filosofia. Pontifícia Universidade Católica do Rio de Janeiro, Rio de Janeiro, 2009

GOFF, J. História e Memória. São Paulo: Editora da UNICAMP, 1990.

GUINSBURG, J. (org.). O Romantismo. São Paulo: Perspectiva, 2005

HERDER, J. G. Traité sur l'origine de la langue. Paris: Éditions Aubier Montaigne, 1977.

NALDINI, N. Pasolini, biographie. Paris: Édions Gallimard, 1989.

PASOLINI, P. P. As últimas palavras do herege: entrevistas com Jean Duflot. São Paulo: Brasiliense, 1983.

Empirismo Hereje. Lisboa: Assírio e Alvim, 1982.

II pórtico della morte. Roma: Fondo Pier Paolo Pasolini, 1988.

. Novas Questões Linguísticas. In: Diálogos com Pasolini. Escritos 1957-1984. São Paulo: Nova Stella/ Instituto Cultural Ítalobrasileiro, 1986.

Mesquinhez da história e imensidão do mundo camponês. Tradução: Alexandre Pitati. In: 0 desejo anticapitalista de Pier Paolo Pasolini. Carta Capital. Jul. 2014. [Acesso em meio eletrônico: cartacapital.com.br]. 
. Passione e Ideologia. Milano: Garzanti, 1973.

Mondadori, 1999.

Saggi sulla letteratura e sull'arte. Milano: Arnoldo

PENNA, M. D. Giuseppe Ungaretti: appunti di viaggio. Theorèin. Palermo: Manfredi Editore. Capitulo 4. Set. 2014. Disponível em: http://www.theorein.it/letteratura/letita/ungaretti/capitolo\%204.html.

REIS, P. Indivíduo e Destino: o significado do Mundo Histórico no Dante de Auerbach (mimeo).

RIALL, L. The Italian Risorgimento: state, society, and national unification. Londres: Taylor \& Francis e Library, 1994.

RICCI, A. Benedetto Croce. Porto Alegre: UFRS, 1966.

ROSENFELD, A. (org.). Autores pré-românticos alemães. São Paulo: E.P.U, 1991.

ROSSI, P. Sinais do tempo: história da Terra e história das nações de Hooke a Vico. São Paulo: Companhia das Letras, 1992.

ROUSSEAU, J. J. Ensaio sobre a origem das línguas. São Paulo: Abril Cultural, 1978.

SCHLEGEL, F. Conversa sobre poesia e outros fragmentos. lluminuras, 1994.

SELIGMAN-SILVA, M. Friedrich Schlegel e Novalis: poesia e filosofia. In: Terceira Margem. n. 10. 2004

STAROBINSKI, J. Jean-Jacques Rousseau: a transparência e o obstáculo; seguido de Sete ensaios sobre Rousseau. São Paulo: Cia. das Letras, 2011.

VICO, G. Ciência Nova. Rio de Janeiro: Record, 1999.

VITTORINI, D. Benedetto Croce e la critica: Considerazioni sul recente suo lavoro: poesia popolare e poesia d'arte. Itálica. vol. 12, n. 2. Jun. 1935. p. 140. Disponível em: http://www.jstor.org.

WERKEMA, Andréa S. Macário, ou do drama romântico em Álvares de Azevedo. 245f. Tese (Doutorado em Letras). Faculdade de Letras. UFMG, Belo Horizonte, 2007.

WERLE, Marco Aurélio. Winckelman, Lessing e Herder: estéticas do efeito? In: Trans/Form/Ação. São Paulo, 23: 19-50, 2000. 